\title{
O PAPEL DA LEVANTADORA NAS EQUIPES DE VOLEIBOL: UM ESTUDO DA REPRESENTAÇÃO SOCIAL DAS CARACTERÍSTICAS DESSA ATLETA NAS OPINIÕES DOS TÉCNICOS E ATLETAS
}

ROSEMEIRE DE OLIVEIRA

Dissertação apresentada à Escola de Educação Física e Esporte da Universidade de São Paulo, como requisito parcial para obtenção do grau de Mestre em Educação Física.

ORIENTADOR: Prof. Dr. ANTONIO CARLOS SIMÕES 


\section{AGRADECIMENTOS}

Nada se compara à euforia de, finalmente, ter conseguido o instrumento para ser ouvida! Agradecer é reconhecer que a estrada poderia ter sido muito mais turbulenta se estas pessoas não estivessem ao meu lado:

Aos meus pais Antonio e Liéte pelo incentivo aos estudos.

À minha irmã Márcia pelas críticas sempre positivas e a tia Aidèe pelas correções do meu português ruim.

Aos meus amigos que sempre estiveram do meu lado de uma forma ou de outra e aqueles que conheci durante o processo.

Ao Prof. Dr. Fernando Lefèvre e a Profa. Dra. Ana Maria Cavalcanti Lefèvre pela orientação metodológica do trabalho.

À Dra. Neuza Guaraciaba dos Santos Oliveira pela ajuda na tabulação dos dados do projeto.

Um agradecimento especial àquele que me deu a oportunidade, com os ouvidos abertos, os olhos fechados e o coração quente...Mais que um profissional, um amigo: meu orientador Prof. Dr. Antonio Carlos Simões.

Aos funcionários que sempre auxiliaram da forma mais simpática e produtiva possível.

Aos técnicos e atletas que gentilmente cederam as entrevistas.

À Mayara - minha sobrinha, afilhada e filha de coração.

À você que está lendo este trabalho.

Como meu primeiro trabalho, é evidente que deve oferece-lo a Deus, por ter me feito entender que só dependia de mim.... 


\section{SUMÁRIO}

Página

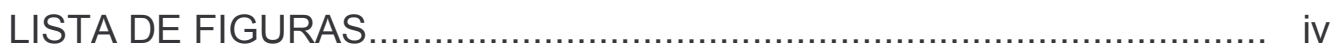

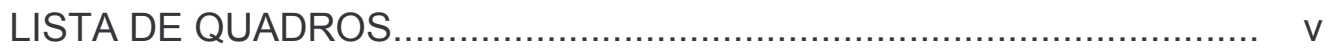

LISTA DE APÊNDICES.......................................................... vi

RESUMO ............................................................................ viii

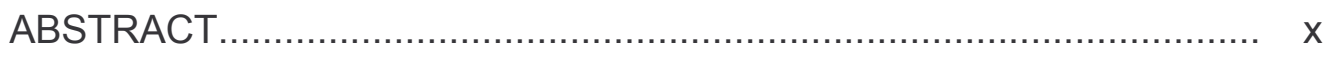

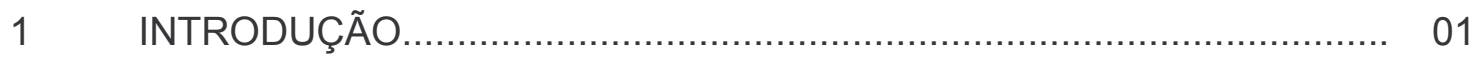

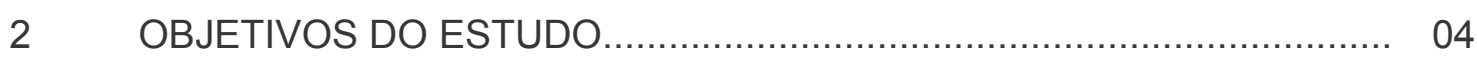

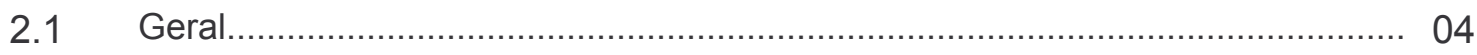

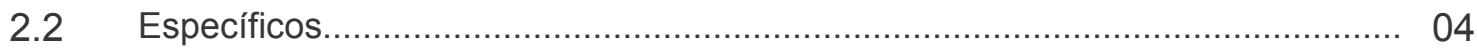



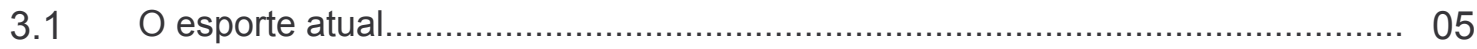

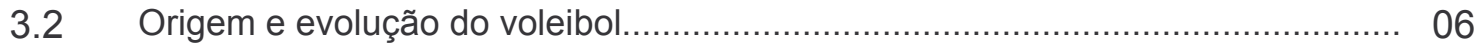

3.3 O atleta levantador no voleibol.................................................................... 10



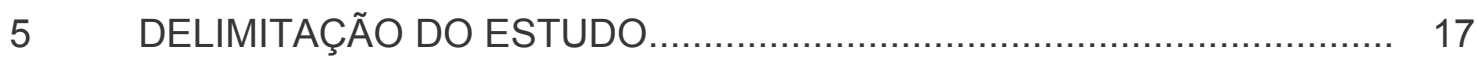

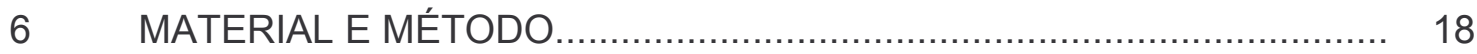

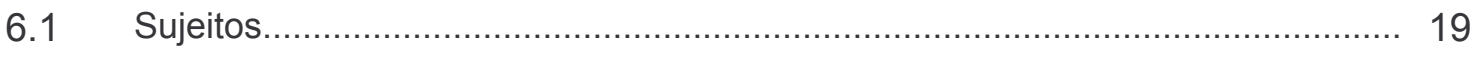

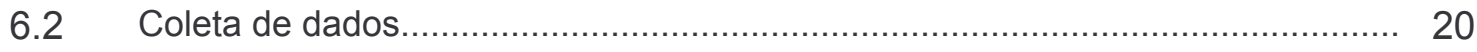

$6.3 \quad$ Instrumento de pesquisa..................................................................... 20

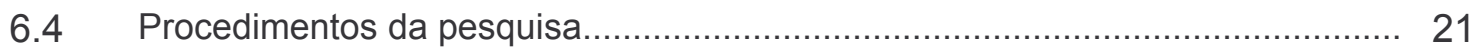

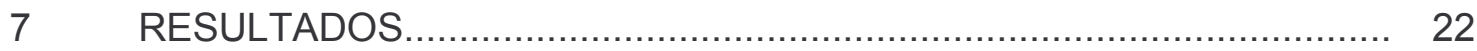

8 DISCUSSÃO

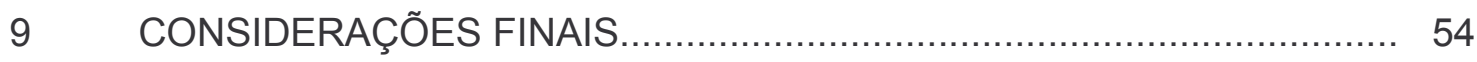



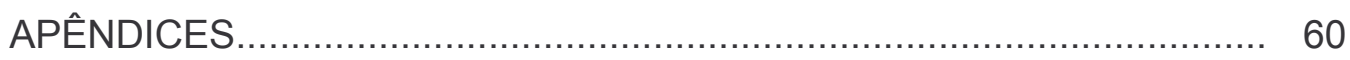




\section{LISTA DE FIGURAS}

Página

FIGURA 1 - $\quad$ Força das Idéias Centrais dos discursos - valores absolutos ...................................................................... 53

FIGURA 2 - $\quad$ Força das Idéias Centrais dos discursos - valores percentuais..................................................................... 54 
LISTA DE QUADROS

Página

QUADRO 1 - Expressões Chave e as respectivas Idéias Centrais dos discursos emitidos......................................................... 23

QUADRO 2 - Categoria A - Expressões Chave e Idéias Centrais dos Aspectos Físicos...................................................... 33

QUADRO 3 - Discurso do Sujeito Coletivo (DSC) da Categoria A (Aspectos

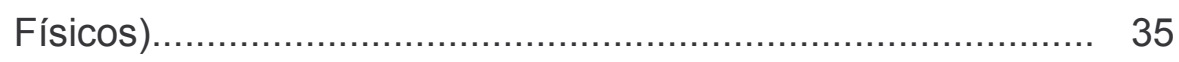

QUADRO 4 - Categoria B - Expressões Chave e Idéias Centrais dos Aspectos Técnicos...................................................... 37

QUADRO 5 - Discurso do Sujeito Coletivo (DSC) da Categoria B (Aspectos

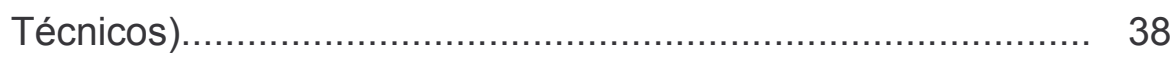

QUADRO 6 - Categoria C - Expressões Chave e Idéias Centrais dos Aspectos Táticos.

QUADRO 7 - Discurso do Sujeito Coletivo (DSC) da Categoria C (Aspectos Táticos)

QUADRO 8 - Categoria D - Expressões Chave e ldéias Centrais dos Aspectos Psicológicos.

QUADRO 9 - Discurso do Sujeito Coletivo (DSC) da Categoria D (Aspectos Psicológicos). 


\section{LISTA DE APÊNDICES}

Página

APÊNDICE I - $\quad$ S1 - Entrevista com um Técnico de Equipe Adulta -

Masculino.............................................................. 60

APÊNDICE II - $\quad$ S2 - Entrevista com uma Atleta Equipe Adulta - Seleção

Brasileira.............................................................. 61

APÊNDICE III - $\quad$ S3 - Entrevista com uma Atleta de Equipe Adulta -

Seleção Brasileira.................................................... 62

APÊNDICE IV - $\quad$ S4 - Entrevista com um Técnico de Categorias

Menores................................................................ 63

APÊNDICE V - $\quad$ S5 - Entrevista com um Técnico Equipe Adulta -

Feminino........................................................... 64

APÊNDICE VI - $\quad$ S6 - Entrevista com um Técnico Equipe Adulta -

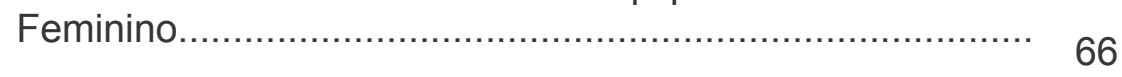

APÊNDICE VII - $\quad$ S7 - Entrevista com uma Atleta Equipe Adulta - Seleção

Brasileira....................................................... 67

APÊNDICE VIII - $\quad$ S8 - Entrevista com um Técnico Equipe Adulta -

Feminino............................................................ 68

APÊNDICE IX - $\quad$ S9 - Entrevista com um Técnico de Categorias

Menores............................................................. 70

APÊNDICE X - $\quad$ S10 - Entrevista com um Técnico Equipe Adulta -

Feminino........................................................... 71

APÊNDICE XI - $\quad$ S11 - Entrevista com uma Ex-Atleta Equipe Adulta -

Seleção Brasileira................................................... 74

APÊNDICE XII - $\quad$ S12 - Entrevista com um Técnico de Categorias

Menores............................................................... 77

APÊNDICE XIII - $\quad$ S13 - Entrevista com um Técnico de Seleção Brasileira de

Categorias Menores............................................... 78 
APÊNDICE XIV - S14 - Entrevista com um Técnico Equipe Adulta -



APÊNDICE XV - S15 - Entrevista com uma Atleta Equipe Adulta - Seleção

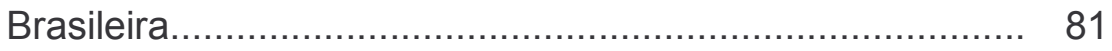

APÊNDICE XVI - S16 - Entrevista com um Atleta Equipe Adulta - Seleção

Brasileira................................................................ 82

APÊNDICE XVII - S17 - Entrevista com um Atleta Equipe Adulta - Seleção



APÊNDICE XVIII - S18 - Entrevista com um Técnico Equipe Adulta Masculino..................................................................... 84

APÊNDICE XIX - S19 - Entrevista com uma Atleta Equipe Adulta - Seleção



APÊNDICE XX - S20 - Entrevista com um Técnico de Categorias

Menores........................................................... 89

APÊNDICE XXI - S21- Entrevista com uma Atleta Equipe Adulta - Seleção

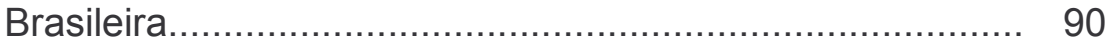

ANEXO XXII - $\quad$ S22 - Entrevista com um Técnico Equipe Adulta -

Feminino.................................................................. 91

ANEXO XXIII - S S23 - Entrevista com uma Atleta Equipe Adulta - Seleção

Brasileira................................................................... 92

ANEXO XXIV - $\quad$ S24 - Entrevista com um Técnico Equipe Adulta -

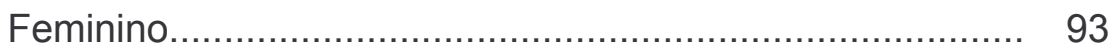


RESUMO

\title{
O PAPEL DA LEVANTADORA NAS EQUIPES DE VOLEIBOL: UM ESTUDO DA REPRESENTAÇÃO SOCIAL DAS CARACTERÍSTICAS DESSA ATLETA NAS OPINIÕES DOS TÉCNICOS E ATLETAS
}

\author{
Autora: ROSEMEIRE DE OLIVEIRA \\ Orientador: PROF. DR. ANTONIO CARLOS SIMÕES
}

As equipes brasileiras de voleibol sempre tiveram os melhores levantadores, no cenário mundial, tais como: William, Jaqueline, Maurício, Fernanda Venturini, entre outros. Esta posição é considerada como a função mais importante. Isto nos leva a acreditar na importância das características físicas, técnicas, táticas e psicológicas de um levantador. Para o estudo foram entrevistados técnicos e atletas de equipes na categoria adulta (masculinas e femininas) participantes da Superliga atual campeonato nacional. Como método utilizou-se uma entrevista semiestruturada com estes técnicos e atletas. Para análise qualitativa foi aplicada a metodologia do DSC (Discurso do Sujeito Coletivo). Trata-se de uma técnica de pesquisa qualitativa que está sendo desenvolvida no campo da saúde desde 1997, mas que tem utilidade em todo tipo de abordagem da temática que envolva o pensamento, o sentimento, as crenças, as atitudes, os valores, as representações sociais, expressados sob a forma de discursos verbais. O procedimento da categorização das respostas (O Pensamento Coletivo como Soma Qualitativa) foi aplicado nessa fase. Consistiu em agrupar as respostas de sentido equivalente, assim como sua força - freqüência com que uma dada Idéia Central apareceu no 
campo pesquisado. Das diversas questões abordadas nesta entrevista, evidenciouse para esta pesquisa a seguinte: "Para você, quais seriam as variáveis que um levantador deve ter para ser um atleta de alto rendimento e chegar a uma seleção nacional?"

PALAVRAS-CHAVE: voleibol, levantadora, perfil, mulher 


\begin{abstract}
SETTER'S PROFILE IN VOLLEYBALL TEAM: SOCIAL REPRESENTATION STUDY OF SETTER'S FEATURE BY COACH'S AND ATHLETES SPEECH
\end{abstract}

\author{
Author: ROSEMEIRE DE OLIVEIRA
}

Adviser: PROF. DR. ANTONIO CARLOS SIMÕES

\begin{abstract}
Brazilian volleyball teams always had the best setters worldwide, such as William, Mauricio, Jaqueline, Fernanda Venturini among others. This position is considered the most important in the team, reason why we may conclude that physical, technical, tactical and psychological characteristics are very important in a setter. The sample was composed of adult teams (male and female) coaches and atlhetes from "SUPERLIGA" - Brazilian National Championship. The methodology used was a semi structured interview. For the qualitative analysis was used the CSS (Collective Subject Speech), a qualitative technical research that is being developed in the Health Area since 1997 and that is helpful for any study involving thinking, attitude, feeling, social representation, beliefs, expressed by verbal speech. The answers computing (collective thinking as qualitative addition) was applied at this time, and consists of joining the same sense answers as well as the incidence of the central idea occurrence in the study. Among all the questions made in this presentation one came up: "What would be the most important characteristics (physical, technical, tactical and psychological) that a setter must have to acquire a high performance profile and reach a National team? ".
\end{abstract}

Keywords: Volleyball, Setters, Profile, Women 


\section{INTRODUÇÃO}

$\mathrm{Na}$ atualidade, o voleibol é um dos fenômenos esportivos que tem proporcionado as maiores emoções. A geração de prata (1984) que era composta por William, Xandó, Renan, Montanaro entre outros, trouxe os holofotes para a modalidade. Os campeões olímpicos de 1992 consagraram o país como uma potência, mas a atual seleção masculina de voleibol foi além: A vitória da equipe sobre Sérvia e Montenegro (antiga lugoslávia), na Liga Mundial de 2003, deu ao Brasil uma supremacia nunca antes vista.

O Brasil alcançou, no ano de 2001, resultados que definitivamente marcaram a história do voleibol mundial. Em 22 competições oficiais internacionais disputadas (Quadra e Praia), conquistou 17 medalhas de ouro e três de prata. Foi o melhor resultado de uma Federação Nacional em todos os tempos (CONFEDERAÇÃO BRASILEIRA DE VOLLEYBALL, 2001).

"O voleibol é o esporte que mais evoluiu nas últimas décadas. Caracterizase pela oposição de dois grupos num marco de relações determinado pelo regulamento do jogo, no qual se contemplam as regras de comportamento e dos limites das ações dos participantes”. (NOCE, 1999, p.47)

"Tem como objetivo fundamental ser um esporte, com atitude altamente competitiva, e habilidade para lutar e vencer, que são essenciais para o sucesso". (BAACKE,1994 citado por NOCE*, 1999, p.49)

Com o início das disputas internacionais, as técnicas, métodos de treinamento, estilos e táticas eram mostrados pelas seleções e os campeões eram sempre imitados e considerados como "escola". Foi assim, através desse intercâmbio, que várias escolas contribuíram para que o voleibol fosse praticado da maneira como é jogado atualmente (BIZZOCCHI, 2000).

Nas últimas décadas, a técnica e tática individual tiveram uma evolução significativa em relação à competência produtiva em todos os postos específicos do jogo. Com mudanças constantes de suas regras e a introdução do atleta na posição

\footnotetext{
* BAACKE, H. International Volley Tech, Switzerland, FIVB, 1994.
} 
de líbero, o comportamento coletivo tornou-se um conjunto de procedimentos individuais/coletivos, em que cada atleta tem de realizar toda a construção de momentos táticos através da recepção do saque, levantamento e ataques efetivos.

A evolução dessas variáveis acompanhou o ritmo e as necessidades do próprio voleibol, com os jogadores se preocupando em evitar o maior número de erros de suas ações, seja no ataque ou na defesa.

"O principal objetivo dos jogos esportivos de alto nível é a competição, que significa lutar contra um oponente para vencer ou perder, de acordo com a estrutura fixada pelos papéis de jogo (NOCE, 1999, p.49)".

VARGAS (1980) comenta que "todo jogador de voleibol deve jogar em uma posição com certa rentabilidade" (p.23). Isso demonstra que esse atleta deve possuir atributos pessoais altamente significativos em relação à sua representatividade social e um perfil adequado às necessidades da modalidade.

Com o desenvolvimento da ciência esportiva, muito se tem buscado, de forma sistemática, adotar um biótipo para cada modalidade esportiva (CALDEIRA, 1986), mas pouco se sabe sobre a avaliação das qualidades psicológicas específicas e importantes para determinadas modalidades e principalmente sobre a especificidade dos jogadores de uma mesma equipe, até mesmo pelo fato de essa disciplina (Psicologia Esportiva) ser muito recente no contexto do treinamento esportivo (SAMULSKI, 1996).

Quando se inicia um trabalho com uma equipe de jovens aspirantes a jogadores de voleibol, questiona-se quem escolher para levantador da equipe. Muitas vezes, a escolha recai sobre aqueles de menor estatura que, por não terem tido um processo rápido de crescimento, são mais coordenados e velozes (RESENDE,1995).

No período de mais de 20 anos em que ocorreram os mais importantes resultados do vôlei brasileiro, apenas duas duplas de levantadores se revezaram na distribuição do jogo das seleções adultas do país em suas principais conquistas (LAJOLO, 2002). A equipe feminina passou a subir ao pódio das mais importantes competições internacionais da década de 1990 representada pela levantadora Fernanda Venturini, que encerrou sua carreira na seleção em 1998, possibilitando a Fofão assumir a sua função na equipe. Em 2002 essa atleta deixa a seleção por 
problemas com o técnico Marco Aurélio Motta, época em que não se preocupava com a renovação desta posição.

No masculino, o reinado da dupla William-Maurício começou mais cedo. William ficou na seleção de 1973 a 1989, quando Maurício assumiu a posição de titular. Em agosto de 2003, Maurício completou 500 jogos pela seleção brasileira. Exemplo disso é que Cida Santos em uma reportagem intitulada "Futuro ameaçado", Folha de S.Paulo, 05 de março de 2001, diz o seguinte:

Você sabia que na próxima Superliga feminina os clubes só poderão ter uma segunda atleta estrangeira se ela for levantadora? Essa resolução da CBV, que ainda não foi divulgada oficialmente, merece reflexão, já que pode trazer conseqüências sérias para o futuro da seleção. Para quem acompanha o vôlei não é novidade: a maior dificuldade hoje no país é a falta de novas grandes levantadoras.

Outra reportagem divulgada pela assessoria de imprensa da Federação Paulista de Volleyball (FPV) em 05 de março de 2001, destacava o mesmo fato. "Vôlei - garimpando talentos - peneira aponta para uma realidade: faltam levantadores no Brasil". "Foram avaliados 231 atletas e apenas um atleta apresentou características para a posição de levantador", disse Roberto Santi - técnico da equipe juvenil e auxiliar de Mauro Grasso na equipe adulta do EC Banespa.

Consciente e preocupado com a carência e o futuro nesta posição, o técnico da seleção brasileira masculina, Bernardinho, revelou em entrevista à assessoria de imprensa da Confederação Brasileira de Volleyball (CBV) que dois atletas já estão sendo observados e merecem ser analisados para o futuro.

Neste contexto surge a necessidade de se concentrar as perguntas no âmbito de nossas equipes de voleibol, centrando-as na figura desse atleta e procurando entender as mudanças por que passa essa modalidade. Que as informações advindas dessas pesquisas se transformem em ferramentas válidas 
para orientar a seleção dos atletas na posição de levantador, visando a rendimentos superiores nas competições.

\section{OBJETIVOS}

\section{$2.1 \quad$ Geral}

Investigar se o papel representativo das atletas na posição de levantadoras de equipes de voleibol feminino poderia ser delineado, em relação às variáveis físicas, técnicas, táticas e psicológicas, mediante a construção do pensamento coletivo dos técnicos e atletas da referida modalidade esportiva coletiva.

\section{$2.2 \quad$ Específicos}

- Testar a eficiência do modelo do pensamento coletivo constituído pelos depoimentos dos técnicos e atletas como método qualitativo, e eficaz na identificação de características pessoais de atletas que ocupam a posição de levantador em equipes de voleibol feminino.

- Verificar se os aspectos físicos, técnicos, táticos e psicológicos do comportamento das levantadoras, quando analisados concomitantemente, podem ser associados a idéias que levam a caracterizar os perfis das atletas levantadoras de equipes de voleibol feminino.

- Verificar se há predominância significativa entre os aspectos físicos, técnicos, táticos e psicológicos do comportamento das atletas levantadoras de equipes femininas de voleibol. 


\section{1 $\quad 0$ esporte atual}

Não há outra atividade no mundo moderno que gere mais entusiasmo, interesse e emoção que o esporte. Nunca na história da humanidade um ramo de nossa vida cultural e social foi tão dominante quanto o esporte hoje em dia. Nenhum evento alcança tantas pessoas ao mesmo tempo quanto os Jogos Olímpicos ou as Copas do Mundo de futebol. (NUZMAN, 1984 citado por MARCHI JUNIOR*, 2001, p.12)

A história dos esportes e dos jogos faz parte da história do Homem. O aparecimento da bola foi o fator mais significativo na história dos jogos esportivos. GUTEMBERG (2000) cita que, de acordo com a Enciclopédia Britannica, a observação de que os animais gostam de fazer piruetas com coisas que lhes servem de brinquedos, e que talvez nunca tenha havido uma época em que não se corria atrás de, nem se lançava, um substituto da bola. Importante é salientar que no princípio, essas atividades eram apenas recreativas e divertidas, sem as correrias que o capitalismo impõe. O esporte de competição veio depois, envolvendo esforço físico aliado a certa técnica.

O mundo do esporte e da atividade física está mudando, e por isso, as organizações - assim como os indivíduos - vêem-se obrigados, cada vez mais, a refletir sobre o caminho a seguir no futuro, sobre o que fazer, qual a direção a tomar. Em outras palavras, vêem-se obrigados a se planejarem.

De acordo com ROCHE (2002), o planejamento tem a ver com os processos de mudança ocorridos no esporte. Alguns desses aspectos são citados pelo autor:

\footnotetext{
* NUZMAN, C.A . Gazeta Esportiva. São Paulo, 2001.
} 
- A distorção do esporte pela TV, que mercantiliza a atividade, profissionalizando-o nos aspectos que afetam o espetáculo esportivo, e convertendoo em um elemento básico da indústria do entretenimento, em que as modalidades em determinado nível - que não contam com recursos econômicos externos, estão predestinadas a desaparecer.

- Aumento significativo da variedade e diversidade de ofertas esportivas. O esporte na década de 80 , era um modelo linear em si mesmo: $80 \%$ da prática esportiva estava concentrada no esporte federado, com objetivo competitivo, de superação e de melhora progressiva.

- Hoje, as pessoas não querem apenas praticar um esporte; buscam várias atividades. A atividade física livre, que tem o elemento de saúde e cuidado do próprio corpo, representa $80 \%$ dos atendimentos das instalações esportivas, em contrapartida dos $20 \%$ representativos do esporte federado.

\subsection{Origem e evolução do voleibol}

"O que mais conta no jogo é receber a bola com boa técnica, mas não é bom jogador aquele que não sabe devolver com arte e agilidade a bola que tenha recebido" (p.17). Esta frase descrita por BIZZOCCHI (2000), poderia ter sido dita por qualquer profissional que atua no voleibol, porém, quem escreveu foi um filósofo greco-romano Sêneca (4-65 d.C.), segundo o autor, discorrendo sobre um jogo associado com atividades de rebater objetos - um jogo parecido com o voleibol que era praticado pelos contemporâneos de Jesus Cristo.

O voleibol teria nascido na Alemanha, entre os militares que, no final do século XIX, já sonhavam com a nação tedesca na liderança da Europa e do planeta (LANCELLOTTI, 1994).

Originalmente, se tratava de um esporte de pontaria e de agilidade.

O jogo denominado "Faust-Ball" - Faust no idioma germânico significa punho - era praticado por equipes compostas de duas a nove pessoas, dependendo do tamanho do espaço. O jogo se desenvolvia em um areial ou gramado, demarcado na forma retangular, onde se levantava uma corda, em sentido horizontal, bem no meio da figura geométrica. A bola tinha que ultrapassar a rede, e cair no campo 
adversário - os jogadores utilizavam os punhos e a bola podia tocar no chão duas vezes antes de ser golpeada. Sem tempo para terminar, o que mais interessava, além do resultado final - um vencedor, era o esforço físico, a procura da concentração.

Nos Estados Unidos se transformou em uma modalidade de competição, quando foi adaptado às peculiaridades da organização de Willian G. Morgan, diretor da Associação Cristã de Moços (ACM), de Massachusetts, em 1895.

No final do século XIX, os americanos dedicavam-se a esportes específicos nas diferentes estações do ano. No inverno se recolhiam aos ginásios fechados para participarem de atividades físicas e desportivas, especialmente as de ginástica - predominantes nas instituições sociais esportivas da época. O fato é que os desportistas eram impedidos de praticar atividades desportivas no período do inverno. Antes, em 1891, James Naismith, também da Associação Cristã de Moços (ACM), implementou diversas atividades desportivas, dentre elas, o basquetebol que foi aceito de imediato. O basquetebol se popularizou entre os desportistas dos Estados Unidos e começou a ser praticado em todas as ACMs americanas.

Em 1894, Naismith incentiva Morgan a ingressar numa escola destinada a trabalhadores Cristãos da ACM da cidade de Springfield. Em 1895 foi transferido para a cidade de Holioke, Massachussetts, onde assumiu o cargo de diretor do Departamento de Atividades Físicas da ACM local. A pedido do pastor Lawrence Rinder, Morgan aceita o desafio de elaborar um jogo menos vigoroso que o basquetebol, que exigia o contato direto entre os seus praticantes, e mais recreativo que a Calistenia - ligada a exercícios ginásticos - e praticado pelos associados de meia-idade. O que Morgan não imaginava era que estava idealizando um esporte que no futuro se tornaria uma modalidade Olímpica, e praticado por milhares de pessoas no mundo inteiro.

Para começar, o jogo era praticado num espaço físico separado por uma rede de tênis, aumentada para 1,98m, e uma bola de basquetebol passou a ser utilizada com a implementação de algumas regras. No início de 1896, Morgan foi convidado por um diretor da Escola de Trabalhadores Cristãos da ACM de Springfield para presenciar um novo jogo, que por sugestão foi chamado de voleibol 
- expressão proveniente do verbo inglês to volley, que significa trocar rebatidas em que a bola permanecia em constante voleio sobre a rede.

Apesar de todo o entusiasmo do início, a propagação deste esporte foi muito pequena nos anos seguintes, retomando seu impulso em todo o país a partir de 1915, quando a prática do jogo passou a fazer parte dos programas de Educação Física das escolas americanas, mediante uma resolução dos órgãos governamentais de Educação.

No ano de 1946, a National Recreation Associations (NRA) divulga em sua publicação que o voleibol é o quinto esporte mais praticado nos Estados Unidos com mais de cinco milhões de participantes. Com a criação das unidades internacionais da ACM no início do século XX, o voleibol chega a outros países. Na América do Sul, o primeiro país a conhecer o voleibol foi o Peru, em 1910. O Uruguai tem conhecimento do jogo em 1912 e o Brasil, três anos mais tarde, apesar das controvérsias sobre ano e local da primeira exibição. Alguns autores informam que ocorreu no Colégio Marista de Recife enquanto outros dizem que aconteceu na ACM de São Paulo (FEDERAÇÃO INTERNACIONAL DE VOLLEYBALL, 1994).

O voleibol sempre esteve ligado à imagem de um esporte recreativo praticado por mulheres e homens de meia idade, porém a sua prática por soldados americanos na Segunda Guerra Mundial fez com que o esporte fosse aceito como vigoroso, dinâmico e possível de ser praticado também por homens fortes (BIZZOCCHI, 2000). Só depois da Segunda Guerra Mundial, com sua importação pelo Japão e pelas nações socialistas, o esporte se valorizou, inclusive no plano das seleções (LANCELLOTTI, 1994).

Nos anos 1960, o voleibol passa a ser considerado o esporte mais popular em 25 países e, após os Jogos Olímpicos de Tóquio em 1964, os Campeonatos Europeus lotam os ginásios em que são disputados.

O Brasil representa as Américas no torneio masculino da Olimpíada de Munique, em 1972. Fracassou, perdendo cinco dos sete jogos que disputou e terminou na oitava colocação, exatamente entre oito seleções. A partir daí o voleibol brasileiro inicia sua ascensão dentro da modalidade. Um crescimento lento, mas seguro, com as sementes da renovação proposta por Carlos Arthur Nuzman, que, no comando da Confederação Brasileira de Volleyball (CBV), levaria a modalidade, no 
comecinho da década de 1990, à vice-liderança dos esportes no país, atrás apenas do evidente futebol.

O processo de transformação do voleibol nacional possui certas particularidades, como descreve MARCHI JUNIOR, em 2001:

No final da década de 1960, e início dos anos 70, o cenário internacional conheceu a revolução implantada por uma escola oriental que estipulava novas formas de jogar e novas metodologias de treinamento, capazes de melhor preparar seus atletas para as competições da modalidade. A eficiência e a eficácia dessas novas formas de jogar e dessas metodologias de treinamento se fizeram notar pelo fato de o Japão conquistar o primeiro lugar masculino nas Olimpíadas de 1972, em Munique. (p.10)

A forma inicial pela qual o voleibol nacional era praticado no Brasil, foi revista após a visita do técnico e precursor do voleibol asiático Yasutaka Matsudaira, que não limitou sua intervenção apenas às quadras, às técnicas e às táticas apuradas dos orientais, ou ainda ao treinamento físico. Os aspectos das estruturas administrativas e organizacionais foram outros pontos chaves da modalidade, que no ano de 1975 teve o marco da administração de Carlos Arthur Nuzman.

O voleibol começa se mostrar melhor preparado taticamente, e a preparação física passa a ter tratamento especial.

Incessantes atualizações de regras desde 1897 quando foram introduzidas, marcam a história da modalidade (RUSSO, 1995). O voleibol brasileiro mudou a partir de 1980, quando houve a explosão desse esporte e a condição física do jogador foi priorizada e a técnica, aprimorada e também facilitada pelo aparecimento de empresas que permitiram que esses atletas pudessem se dedicar exclusivamente à modalidade (BRUNORO, 1987). Na Olimpíada de Los Angeles, EUA, em 1984, o Brasil conseguiu ganhar a sua primeira medalha olímpica no voleibol, ficando com a medalha de prata. 
Analisando as peculiaridades contidas na história dessa modalidade MARCHI JUNIOR, em 2001, cita que desde a sua criação, o voleibol apresentou transições, como viradas - denominadas passagens do período de amadorismo para o de profissionalismo e posteriormente de espetacularização do esporte.

Desenvolveu-se por conta de uma trajetória pautada na criação de um jogo com características específicas para atender aos anseios de um determinado grupo social, passando pelo discurso de componente, a formação integral na Educação Física escolar, chegando aos dias atuais em que se encontram equipes de competição inseridas na espetacularização e profissionalização do esporte (MARCHI JUNIOR, 2001).

Com as façanhas da equipe brasileira masculina nos Jogos Olímpicos de Barcelona em 1992 - primeiro esporte coletivo a conquistar uma medalha de ouro olímpica para o Brasil, assim como o Campeonato Mundial de 2002, seguido por um vice campeonato mundial no Brasil em 1994 e da medalha de bronze conquistada nos Jogos Olímpicos de Atlanta em 1996 e de Sydney em 2000, pela seleção feminina, a modalidade se tornou atrativa para a prática por jovens, isso evidenciado pelo espaço que tem na mídia e pela popularidade alcançada.

\subsection{O atleta levantador no voleibol}

"Nenhuma surpresa no Campeonato Paulista de Voleibol de 2002. Os favoritos ficaram com o título". (SANTOS, 2001, p.D6). Em sua coluna no jornal Folha de São Paulo, Cida Santos comenta a reportagem com o título acima, a parceria entre o ex-levantador e técnico campeão olímpico em Barcelona José Roberto Guimarães, e a levantadora Fernanda Venturini. Nessa parceria estão presentes características da levantadora que são: habilidade, rapidez, eficiência, inteligência, variação de jogo e ousadia.

Na percepção de HIPPOLYTE (1998), o levantador no jogo de voleibol é considerado o pivô da equipe. E uma equipe que possui um bom levantador estaria pré-determinada para o sucesso em qualquer nível. O termo denominado Levantamento, é originário do princípio do voleibol - que na antiguidade estava ligado com o simples levantar de uma bola alta para o atacante (SILVA, 1985). 
Atualmente o termo continua o mesmo, mas passou a representar uma tática fundamental para o sucesso de uma equipe de alto-rendimento. A maioria das equipes em nível internacional, por exemplo, jogam no sistema 5x1 - com exceção da equipe feminina de voleibol de Cuba, que joga dentro de um sistema denominado de $4 \times 2^{2}$. O sistema $5 \times 1$ caracteriza que a equipe está usando um único levantador em conjunto com cinco atacantes. O levantamento ocorre nas seguintes ocasiões:

- Após a recepção do saque;

- Na transição do sistema defensivo para o ofensivo, após defesa ou amortecimento da bola pelo bloqueio.

Com a própria evolução da modalidade, o levantamento passou a ser encarado de forma diferente - já não é simplesmente erguer uma bola alta para o atacante. Hoje, as variações de ataque obrigam o levantador (atleta que executa esse fundamento) a ter uma habilidade diferenciada para obter sucesso em sua posição. Para ARAÚJO (1999) citado por ZANATTA* (2000),

\begin{abstract}
O levantador é o elemento da equipe que executa o passe (levantamento) para o ataque como função principal no jogo - a partir da análise da situação e tendo em linha de conta o plano de jogo e o sistema de organização coletiva, decide a solução ofensiva a adotar, ou seja, realiza a distribuição". (p.11)
\end{abstract}

Em seus estudos, MOUTINHO (2000) também citado por ZANATTA* (2000) escreveu que "equipes masculinas com melhor distribuição relativa, venceram $90 \%$ dos sets e $87 \%$ dos jogos e as equipes femininas $63 \%$ dos sets e $82 \%$ dos jogos". (p.20)

\footnotetext{
${ }^{2}$ Sistema 4X2: Sistema caracterizado quando a equipe utiliza dois levantadores em conjunto com quatro atacantes.

* ARAÚJO, C.J.P.R. Monografia não publicada, Porto, 1999.

* MOUTINHO, C.A.S.S. Tese de Doutorado, Porto, 2000.
} 
Segue-se que na formação de equipes jovens, existe todo um questionamento em relação às características dos atletas que as compõem, especialmente do perfil ideal para um atleta ser o levantador - as escolhas, geralmente recaem sobre aqueles atletas de menor estatura e com habilidades coordenativas, ágeis em relação ao fundamento toque. A escolha pode se revelar correta algumas vezes, mas não se pode considerar como único fator de seleção. Com a equiparação do biótipo físico dos atuais atletas da modalidade acredita-se que sejam necessários maiores estudos sobre a especificidade de cada jogador na sua posição de atuação.

No voleibol atual o levantador assume uma função central no desenvolvimento estratégico do jogo, e por isso muitas vezes é chamado de "cérebro" ou mesmo a "alma" da equipe (CORDEIRO FILHO, 2002; MESQUITA \& GRAÇA, 2002). Por ele passam todas as jogadas - sempre decisivas da sua equipe. É o atleta que tem de processar a maior quantidade e variedade de informações e tomar as decisões. Isto não o isenta de possuir excelente capacidade de execução técnica. Diríamos que a combinação da melhor técnica com a capacidade de obter a melhor solução para cada situação do jogo seria o fato que caracteriza os bons levantadores de voleibol.

Em seu estudo sobre o conhecimento estratégico de um levantador de alto-nível, MESQUITA e GRAÇA (2002), obteve como resultados os seguintes tópicos quanto à distribuição entre um bom e um excepcional levantador:

- Os traços de personalidade constituem requisitos necessários para o levantador: a liderança (primeira característica que alguém deve possuir se pretende ser um levantador excepcional), o não egoísmo, a dedicação à equipe e o espírito de grupo;

- Virtuosismo técnico e tático: explorar os pontos fracos do adversário e evitar denunciar as decisões que vão ser tomadas, gestor de risco.

CORDEIRO FILHO (2002) enfatizou que o levantador é peça fundamental para a eficácia do ataque. Cita como características necessárias para essa função:

- Qualidades Físicas: agilidade, velocidade, postura, movimentação, potência muscular, coordenação, ritmo;

- Qualidades Técnicas: domínio motor das habilidades específicas; 
- Qualidades Táticas e Mentais: equilíbrio emocional, autodisciplina, concentração, sensibilidade, percepção, criatividade e decisão rápida.

É claro que numa equipe de voleibol, o levantador é aquele atleta encarregado de organizar as ações de ataque, e dentro da competição de alto rendimento se faz necessário render e fazer render ao máximo seus atacantes (CARDONA, 2001; MOUTINHO, BARRADAS \& RAMOS, 1998).

Para ter um bom desempenho na competição de alto-nível o levantador deve apresentar as seguintes características, descritas pelos autores acima:

- Realizar o gesto técnico de forma precisa de todas as partes da quadra;

- Diferenciar corretamente os diferentes tempos do levantamento;

- Utilizar inteligentemente os nove metros da quadra, bem como os seus atacantes;

- Intuir os momentos positivos ou negativos de seus atacantes;

- Conhecer qual é a maneira mais eficaz para recuperar um atacante em dificuldade.

Para a seleção do levantador CARDONA (2001), sugere os seguintes pontos:

- Deve apresentar o perfil técnico, tático e mental anteriormente mencionado;

- Deve ser capaz de desenvolver o jogo pretendido pelo técnico;

- Deve ser capaz de fazer render ao máximo o potencial da equipe;

- Deve ser capaz de impor sua personalidade ao grupo.

O levantador, conforme BARROS (2001) deve possuir qualidades essenciais, como descritas a seguir:

- Excepcional capacidade técnica individual;

- Discernimento estratégico/tático;

- Liderança;

- Altruísmo.

Como se vê, o levantador se torna o principal elemento dentro do comportamento coletivo das equipes de voleibol. McGOWN, FRONSKE \& MOSER 
(2001) citam que para selecionar o atleta certo para a posição, os atributos ideais abaixo descritos devem ser observados:

- Bom condicionamento físico;

- Atitude correta: deve ser emocionalmente estável;

- Trabalhar junto com o técnico;

- Solucionador de problemas;

- Observador;

- Líder;

- Fisicamente forte;

- Bom bloqueador;

- Bom sacador;

- Disciplina;

- Criatividade;

- Tempo de reação;

- Altruísta;

- Bom comunicador;

- Jogador de equipe;

- Alto e com grande impulsão vertical;

- Ser canhoto.

MOUTINHO (2000) citado por ZANATTA (2000), reconhece que os fatores antropométricos, técnico-coordenativos, tático-cognitivos, psicológicos e condicionais seriam os elementos determinantes da performance dos atletas, como descritos abaixo:

- Fatores antropométricos: estatura, peso, composição corporal;

- Fatores técnico-coordenativos: agilidade, ambidestria, coordenação, constância de execução, facilidade de execução do passe, precisão, técnica de execução do passe, ritmo, timing, técnica de deslocamento, velocidade de deslocamento, velocidade de execução, velocidade de reação e visão periférica;

- Fatores tático-cognitivos: capacidade de percepção, capacidade de análise, capacidade de antecipação e capacidade de decisão; 
- Fatores psicológicos: autoconfiança, auto-controle, criatividade, liderança, motivação, combatividade, espírito de equipe, equilíbrio emocional, concentração, capacidade de trabalho;

- Fatores condicionais: força, flexibilidade, resistência, velocidade de deslocamento, velocidade de reação.

MÈIER (1995) propõe que os levantadores devem ser selecionados com base nas habilidades coordenativas, controle de bola e altura. Necessitam grande desenvolvimento da sensibilidade quando manejam a bola. Além disso, devem ser ágeis, velozes, flexíveis e eficientes em seus movimentos, bons defensores e fortes no bloqueio. Inteligentes, de personalidade forte, líderes, determinados e leais ao seu treinador na implantação dos planos de jogo, são atributos psicológicos desse atleta. Isto significa que discorrer sobre o levantador é dizer do cotidiano desse atleta, que assume uma postura específica em relação ao esporte. A sua principal responsabilidade é a de conceber a dinâmica do jogo de sua equipe. São inúmeras as variações que influem nas decisões que deve tomar a todo instante para que o ataque e o contra-ataque de sua equipe possam fluir positivamente (RESENDE, 1995). Um levantador que persegue a excelência tem que desenvolver as seguintes características a seguir:

- Conhecimento da sistemática do jogo; ser um estrategista;

- Conhecimento das características de seus atacantes e dos bloqueadores adversários e auto-conhecimento;

- Dedicação;

- Perseverança;

- Liderança;

- Sensibilidade;

- Altruísmo;

- Grande capacidade de percepção e poder de análise;

- Precisão;

- Velocidade de deslocamento;

- Tomada de decisão.

Como descrito na literatura por MATSUDO (1986) e SILVA (1987), os levantadores são normalmente os atletas mais baixos, porém têm muitos recursos: 
são ágeis, velozes, hábeis e com tempo de reação muito vivo; têm boa visão periférica e são capazes de resolver problemas rapidamente e tomar decisões em um instante. Sobre seu caráter, é generoso, abnegado, altruísta e inteligente; deve ter muita experiência de jogo e competição. A sua capacidade de defender e levantar bolas em direção aos companheiros caracteriza uma combinação de habilidades coordenativas e técnicas para surtir determinados efeitos táticos durante 0 transcorrer de uma partida de voleibol.

Vimos que os conceitos estabelecidos na revisão de literatura caminham numa dupla direção: para os aspectos psicológicos e para os aspectos táticos que norteiam o comportamento coletivo das equipes de voleibol. Isto nos leva a estabelecer algumas questões fundamentais, a saber:

* Será que o comportamento tático individual das atletas que atuam na

posição de levantadoras assumiria um papel fundamental na eficácia do comportamento coletivo?

* Será que as características das atletas que atuam na posição de levantadoras em equipes de voleibol, estariam mais associadas aos aspectos físicos, ou técnicos ou táticos ou aos aspectos psicológicos?

\section{JUSTIFICATIVA}

Da revisão da literatura e mesmo da nossa - embora pequena experiência profissional na área de educação física e especificamente no âmbito do voleibol, depreende-se que:

Estatura e força aliam-se à habilidade do jogador na posição de levantador da equipe, habilidade essa diferenciada, e que consiste em rapidez, ousadia, eficiência, variação de jogo. Faltam, atualmente, novas grandes levantadoras no voleibol nacional. Parece que a palavra grande se refira tanto a atletas de alta estatura como àquelas cujos traços de personalidade as favoreçam no momento de analisar a situação do jogo, entender-lhes o plano, decidir qual solução ofensiva a adotar, levando a equipe a praticar a verdadeira arte de jogar, com agilidade e gestos precisos. A busca de talentos para o voleibol tem se apoiado ao longo dos anos em 
fatores subjetivos como a observação, a intuição e a própria experiência dos profissionais da área e dos "olheiros".

A ciência esportiva tem oferecido subsídios para a definição de um biótipo para cada modalidade de esporte. O levantador no voleibol, por exemplo, deve possuir qualidades como liderança, dedicação ao grupo, espírito de equipe, concentração, criatividade, entre outras. É sua responsabilidade conceber a dinâmica do jogo de sua equipe.

Combinando habilidades coordenativas e técnicas na tentativa de obter a melhor solução para cada situação de jogo e mesmo sem grande estatura, o levantador, "cérebro" da equipe, é fundamental para o ataque.

Contudo, muito pouco se sabe ainda sobre como avaliar as qualidades psicológicas específicas e importantes não só para uma determinada modalidade, mas principalmente para os jogadores de uma mesma equipe. Faltam estudos sobre o assunto ou falta o conhecimento dos trabalhos existentes? Ou ambos?

Tais questionamentos justificam a nossa pesquisa de opiniões de técnicos de voleibol.

5

\section{DELIMITAÇÃO DO ESTUDO}

O presente estudo delimitou-se a pesquisar:

- Opiniões de técnicos de equipes masculinas e femininas de voleibol consideradas de alto-rendimento na modalidade tanto nas categorias menores (base) como adultas, e dois técnicos de Seleção Brasileira das categorias infanto-juvenil e juvenil feminino que possuem credenciamento Nível ${ }^{3}{ }^{3}$ na Confederação Brasileira de Voleibol, e que Ihes permitisse atuar nessa função, em competições de nível nacional. Opiniões de atletas de equipes femininas de voleibol, nas posições de levantadoras e atacantes e a opinião de um levantador de equipe masculina de voleibol da categoria adulta.

- Os dados foram obtidos durante o período de dezembro de 2002 a abril de 2004, durante a temporada da Superliga Nacional. Não se procurou delimitar a 
coleta de dados de acordo com o tempo de permanência tanto de técnicos como das atletas e do atleta do sexo masculino pesquisado em suas equipes. O critério para a escolha dos técnicos e dos atletas limitou-se ao fato dos mesmos, no momento da coleta, estarem respondendo pela direção técnica e atuando como atletas em suas respectivas equipes. Não foram consideradas diferenças de estrutura organizacional das equipes, cujos técnicos e atletas seriam sujeitos desse estudo.

\section{MATERIAL E MÉTODO}

O método de pesquisa qualitativa em Educação Física, ciência do exercício e ciência do esporte é relativamente novo, porém em outras áreas como a Antropologia, Psicologia e Sociologia, tem sido empregado há muitos anos (THOMAS \& NELSON, 2002).

A idéia de que onde há ciência há conhecimento objetivo, universalmente válido e generalizável e de que onde há este tipo de conhecimento há, necessariamente, números, tabelas, gráficos, percentuais, amostragem representativa, faz parte da cultura que vive e que vulgariza essa idéia (LEFÈVRE e LEFÈVRE, 2000).

A elaboração do Discurso do Sujeito Coletivo (DSC) é uma das formas das quais o pesquisador pode lançar mão para reconstruir o universo de representações existentes no campo pesquisado. Para esta reconstrução é necessária a coleta da matéria prima das representações, ou seja, os discursos professados pelos sujeitos sociais. As representações sociais consistem em entendê-las como a expressão do que pensa determinada população sobre determinado tema e que, como simplificam os autores, são conhecimentos muito próximos da ação cotidiana e que têm a função de guiar, orientar e justificar esta ação.

Trata-se de uma técnica de pesquisa qualitativa que tem utilidade em todo tipo de abordagem da temática que envolva o pensamento, o sentimento, as crenças, as atitudes, os valores, as representações sociais, expressados sob a forma de

\footnotetext{
${ }^{3}$ Nível II - Capacitação Técnica promovida pelo Departamento Técnico da Confederação Brasileira de Voleibol com avaliação teórica e prática para aprovação.
} 
discursos verbais. LEFÈVRE (2001) afirma ainda que o DSC é uma proposta de organização e tabulação de dados qualitativos de natureza verbal, que são obtidos através de depoimentos, artigos de jornal, matérias de revistas, cartas, entre outras formas, e que consiste basicamente em analisar o material coletado, extraindo-se de cada depoimento as Idéias Centrais e suas correspondentes Expressões Chaves.

O DSC (Discurso do Sujeito Coletivo) é uma forma de apresentação de resultados de pesquisas qualitativas sob forma de vários discursos-síntese escritos na primeira pessoa do singular, que expressa o pensamento de uma coletividade, como se essa coletividade fosse o emissor de um discurso.

A sede do pensamento coletivo (discursos na escala social) não pode ser, segundo os autores, uma soma dos discursos individuais e sim o resgate do imaginário social, das representações sociais, do pensamento pré-existente sobre o tema.

\subsection{Sujeitos}

Fizeram parte do presente estudo, três técnicos do sexo masculino, de equipes adultas masculinas, cinco técnicos do sexo masculino, de equipes adultas femininas, quatro técnicos do sexo masculino de equipes menores da divisão especial e dois técnicos do sexo masculino das seleções brasileiras infanto-juvenil e juvenil feminina. Todos com idade cronológica acima de 30 anos e com mais de dez anos de experiência no comando de equipes de voleibol de alto nível, participantes dos principais campeonatos nacionais e internacionais.

Participaram do estudo também, um levantador do sexo masculino de equipe adulta, cinco levantadoras do sexo feminino de equipes adultas, três atacantes do sexo feminino de equipes adultas e uma ex-levantadora do sexo feminino da seleção brasileira, todos com mais de dez anos de carreira esportiva em campeonatos nacionais e internacionais, participantes atuais da Superliga Nacional, com exceção da ex-levantadora da seleção brasileira. 
A seleção dos sujeitos no presente estudo foi baseada na amostragem por critério $^{4}$ de GOETZ e LeCOMPTE (1984) citado por THOMAS e NELSON ${ }^{5}$ (2002), sendo necessário que os técnicos entrevistados, possuíssem o certificado de Nível II (credenciamento mínimo da Confederação Brasileira de Volleyball obtido por curso e avaliação teórica e prática da Comissão Nacional de Treinadores), para atuarem nesta função, na categoria adulta e para os atletas, terem atuado pela seleção brasileira.

\subsection{Coleta de Dados}

Os dados foram coletados durante a Superliga (Campeonato Nacional) de voleibol nas temporadas 2002/2003 e 2003/2004, na cidade de São Caetano do Sul, por ocasião dos jogos que aconteceram contra a equipe da cidade, pela própria pesquisadora.

\subsection{Instrumento de pesquisa}

O método denominado Discurso do Sujeito Coletivo (DSC) - criado e desenvolvido no campo da saúde (LEFÈVRE, 2001) desde 1997 foi utilizado tanto para coletar dados (opiniões) pessoais de técnicos e atletas de voleibol masculino e feminino como caracterizar os perfis de comportamentos das atletas de voleibol na posição de levantadora.

Para que a ocorra a reconstrução do universo das representações, são necessários neste caso, os discursos adotados pelos sujeitos e para isso o método mais freqüentemente utilizado é a entrevista. As entrevistas seguiram o formato estruturado e os dados foram registrados em um gravador para posterior análise (ANEXOS de I a XXIV).

\footnotetext{
${ }^{4}$ Amostragem por critério: Seleção baseada no fato dos sujeitos apresentarem características semelhantes e com quem se pode aprender muito (THOMAS \& NELSON, 2002).

${ }^{5}$ GOETZ, J.P., LeCOMPE, M.D. Education Research, Orlando, 1984.
} 


\subsection{Procedimentos da pesquisa}

Os sujeitos do presente estudo foram convidados pessoalmente pela pesquisadora - informados sobre os objetivos do estudo e que ficaria a critério deles participarem voluntariamente das entrevistas que seriam realizadas mediante um agendamento prévio. Todas as considerações éticas em relação à pesquisa com humanos foram seguidas, a fim de salvaguardar seus direitos de privacidade e garantir anonimato sendo aprovado pelo Comitê de Ética em pesquisa da EEFEUSP.

Os procedimentos do estudo, portanto, foram desenvolvidos por fases, a saber:

FASE 1. Elaboração do roteiro de questões

A questão inserida no contexto da organização da entrevista foi feita em função dos objetivos que se pretendia atingir. Nesse sentido, foi elaborada uma questão para conhecer a percepção dos técnicos e atletas sobre as características necessárias do atleta na posição de levantador no voleibol. A questão elaborada segue descrita abaixo:

Questão: Para você, quais seriam as variáveis que um levantador deve ter para ser um atleta de alto rendimento e chegar a uma seleção nacional?

Todas as considerações, a fim de que o pesquisador pudesse efetuar com sucesso a entrevista foram seguidas. A apresentação do entrevistador para o entrevistado, a autorização do entrevistado para a gravação do discurso, e o termo de consentimento por escrito do mesmo.

FASE 2. Construção e interpretação do Discurso do Sujeito Coletivo (DSC)

Nesta fase da pesquisa foram extraídas de cada depoimento as Idéias Centrais e suas correspondentes Expressões Chaves (QUADRO 1). A organização dos depoimentos verbais obtidos permitiu a construção do DSC - discursos síntese, redigidos na primeira pessoa do singular, que reúnem em si, trechos literais dos depoimentos individuais de sentido equivalente ou semelhante (QUADROS de 2 a 9). 
Os dados discursivos fornecidos pelos sujeitos foram inseridos no software QualiQuantiSoft ${ }^{6}$ e organizados sob a ótica das representações sociais, estruturandose o Discurso do Sujeito Coletivo (DSC) e preparados sob a forma de duas figuras metodológicas: Expressão-Chave $(\mathrm{ECH})^{7}$ e Idéia Central $(\mathrm{IC})^{8}$, conseguidos a partir de trechos das respostas emitidos pelos sujeitos entrevistados, as quais permitiram a identificação de palavras e expressões. Posteriormente, os discursos foram categorizados segundo similaridades ou equivalências, ou seja, pelo fato de conterem a mesma idéia, como descritos a seguir:

1. Categoria A - Aspectos Físicos;

2. Categoria B - Aspectos Técnicos;

3. Categoria C - Aspectos Táticos;

4. Categoria D - Aspectos Psicológicos.

FASE 3. O Pensamento Coletivo como Soma Qualitativa

O procedimento da categorização das respostas foi aplicado nessa fase. Consistiu em agrupar as respostas de sentido equivalente num conjunto ao qual se lançou um nome que expressasse este sentido, assim como sua força - freqüência com que uma dada Idéia Central apareceu no campo pesquisado (FIGURAS 1 e 2).

\section{$7 \quad$ RESULTADOS}


perfil dos atletas na posição de levantador no voleibol. Os trechos selecionados nos diferentes discursos emitidos (ANEXOS de I a XXIV) estão apresentados a seguir no QUADRO 1.

\footnotetext{
${ }^{6}$ Software desenvolvido por Lefèvre, F. e Lefèvre, AMC. Faculdade de Saúde Pública da USP, 2003.

${ }^{7}$ Expressão-Chave(ECH): trechos selecionados a partir da própria fala dos sujeitos.

${ }^{8}$ Idéia Central (IC): o sentido da fala.
} 
QUADRO 1 - Expressões Chave e as respectivas Idéias Centrais dos discursos emitidos.

\begin{tabular}{|c|c|}
\hline Expressões Chave & Idéia Central \\
\hline $\begin{array}{l}\text { S5 - ...característica técnica muito boa e daí com o } \\
\text { amadurecimento taticamente ele vai melhorando muito ai isso ... } \\
\text { nós temos hoje, tanto no feminino, como no masculino jogadoras } \\
\text { que tem uma dedicação e tem uma disciplina tática muito boa, } \\
\text { mais o aspecto técnico inicial, de discernimento de jogo e malícia } \\
\text { de jogo, realmente diminuiu, então taticamente as jogadoras são } \\
\text { mais obedientes, elas procuram observar mais o jogo, e tal etc... } \\
\text { agora técnica pura, de levantador com uma certa estatura } \\
\text { mediana e que se destaque, e tenha realmente é...malandragem } \\
\text { no bom sentido do jogo, ta faltando mais,... }\end{array}$ & $\begin{array}{l}2^{\mathrm{a}} \quad \text { Idéia } \\
\text { Amadurecimento tático } \\
\text { do levantador }\end{array}$ \\
\hline $\begin{array}{l}\text { S6 - ... eu costumo falar sobre levantadora, gosto muito do } \\
\text { aspecto emocional da levantadora né? Acho que a levantadora } \\
\text { tem que ser uma líder, ela tem que ter uma liderança positiva em } \\
\text { relação às atacantes... então eu gosto muito de puxar nas } \\
\text { minhas levantadoras, isso aqui, essa liderança e esse desafio,... } \\
\text { Então a levantadora tem que ser forte, ela tem que ter } \\
\text { perseverança tem que ser dedicada tem que ser a primeira a } \\
\text { chegar no treino, a última a sair, tem que estar entrosada com o } \\
\text { técnico, em todo o esquema tático, tanto na sua equipe quanto } \\
\text { das outras equipes. Quais são os pontos mais fortes da sua } \\
\text { equipe, e juntos traçar isso no começo da temporada, junto com } \\
\text { o seu técnico e a cada jogo estudar e ver o que é que a gente } \\
\text { pode fazer em relação à equipe adversária, mas principalmente } \\
\text { ter uma liderança em cima das atacantes, pra que as atacantes } \\
\text { não fujam das responsabilidades, colocando sempre a culpa nas } \\
\text { levantadoras. }\end{array}$ & $\begin{array}{l}2^{a} \text { Idéia - A levantadora } \\
\text { tem que ser uma líder. }\end{array}$ \\
\hline $\begin{array}{l}\text { S24 - Olha... eu acho que o principal de um levantador...na parte } \\
\text { psicológica...por que às vezes...muitas vezes quando tem } \\
\text { deficiência física e deficiência técnica, ele consegue fazer o jogo } \\
\text { pelo controle emocional dele e pelo controle que ele tem sobre a } \\
\text { avaliação que ele faz dos companheiros de jogo dele...eu vou } \\
\text { falar mais em termo de feminino por que é onde eu mais } \\
\text { trabalho...então eu entendo que as variáveis psicológicas do } \\
\text { controle emocional a observação e a facilidade de analise do } \\
\text { colega...qual momento eu posso usar esse jogador, qual o } \\
\text { momento eu não posso usar esse jogador, a identificação de } \\
\text { como o jogador reage com determinado tipo de bola ...qual é a } \\
\text { maior eficiência dele qual a maior deficiência dele, como se dirigir } \\
\text { com o jogador que ela vai levantar a bola, se ela deve ser } \\
\text { agressiva , se ela deve ser carinhosa, se ela deve ser } \\
\text { atenciosa...então eu acho que esse é um componente } \\
\text { fundamental pra uma levantadora de altíssimo nível.... }\end{array}$ & $\begin{array}{l}1^{\text {a }} \text { Idéia - O principal de } \\
\text { um levantador é a parte } \\
\text { psicológica. }\end{array}$ \\
\hline
\end{tabular}


QUADRO 1 - Expressões Chave e as respectivas Idéias Centrais dos discursos emitidos (cont.)

S8 - ... eu acho, que o voleibol brasileiro, pela versatilidade que o jogo..... pela dinâmica do jogo, eu acho que ele necessita de grande ... de jogadoras altas, especialmente que tenha o domínio da quadra, do controle do jogo, mesmo, em si, porque para o levantador, principalmente, feminino, ela é fundamental, ela dá o ritmo, ela dá o padrão do jogo e os últimos 10 anos aí a gente vê que o time que tinha a (...) ou a (...) é que eram campeãs da Superliga, com exceção da (...) que eu acho que é, depois das 2 , a terceira grande levantadora do Brasil, assim, uma jogadora habilidosa, né? $\mathrm{E}$ grande, então, ela está adequada a esses padrões, né? Então eu penso nisso, a jogadora tem que ter conhecimento, realmente, do que se passa dentro da quadra, acho que é o principal, é precisão, né? Técnica, pra que ela possa ditar o ritmo do jogo.

S8 - Bem, eu acredito primeiro é no equilíbrio né? Equilíbrio emocional é.... conhecimento de jogo, né? ... Então, a (...) é uma menina que foi uma jogadora que sempre teve muita liderança, que eu acho fundamental, conhecimento de jogo, é ..... equilíbrio, lógico. Equilíbrio quando eu falo é..... se mantém muito equilibrada. Todas elas já convivi, com essas jogadoras todas aí, de perto. Todas elas têm seu momento de desequilíbrio, mas a (...) se mantém por mais tempo em equilíbrio, precisão, né? Técnica.

S10 - ... as jogadoras que foram especializadas desde de pequenininha como levantadora não são as jogadoras que estão é.....dando rendimento entrando na seleção, com exceção da (...) que foi levantadora desde mirim, as outras a gente sempre tem jogadoras que foram atacantes, então eu acho isso já uma situação meio delicada,....

S24 - ... A qualidade seria a variação, o domínio de todos os tipos de variações de toque e de manchete, por que varias situações o jogador não tem possibilidade de chegar de toque e ele tem que ser um bom levantador também de manchete, ter um controle da manchete, o que a gente observa muito, é que o jogador de alto nível, sempre é o melhor defensor da equipe, hoje com a existência do libero caiu um pouco, mas normalmente....você vê, a (...) já ganhou varias vezes como melhor defensora da Superliga e o (...) também, sempre os levantadores estão à frente, por que eles tem uma percepção, uma análise melhor de trajetória de bola, uma análise melhor do atacante pra se posicionar...então essa antecipação ....que também na parte física eu esqueci de colocar ....que é fundamental pra um levantador, essa antecipação da ação que vai acontecer, ou antes, ou depois dele. $2^{a}$ Idéia - Levantadoras altas com domínio de quadra.

$1^{\text {a }}$ Idéia - Equilíbrio emocional do levantador.

$2^{a}$ Idéia - As jogadoras que foram especializadas desde pequenas não rendem.

$3^{a}$ Idéia - As qualidades técnicas do levantador. 
QUADRO 1 - Expressões Chave e as respectivas Idéias Centrais dos discursos emitidos (cont.)

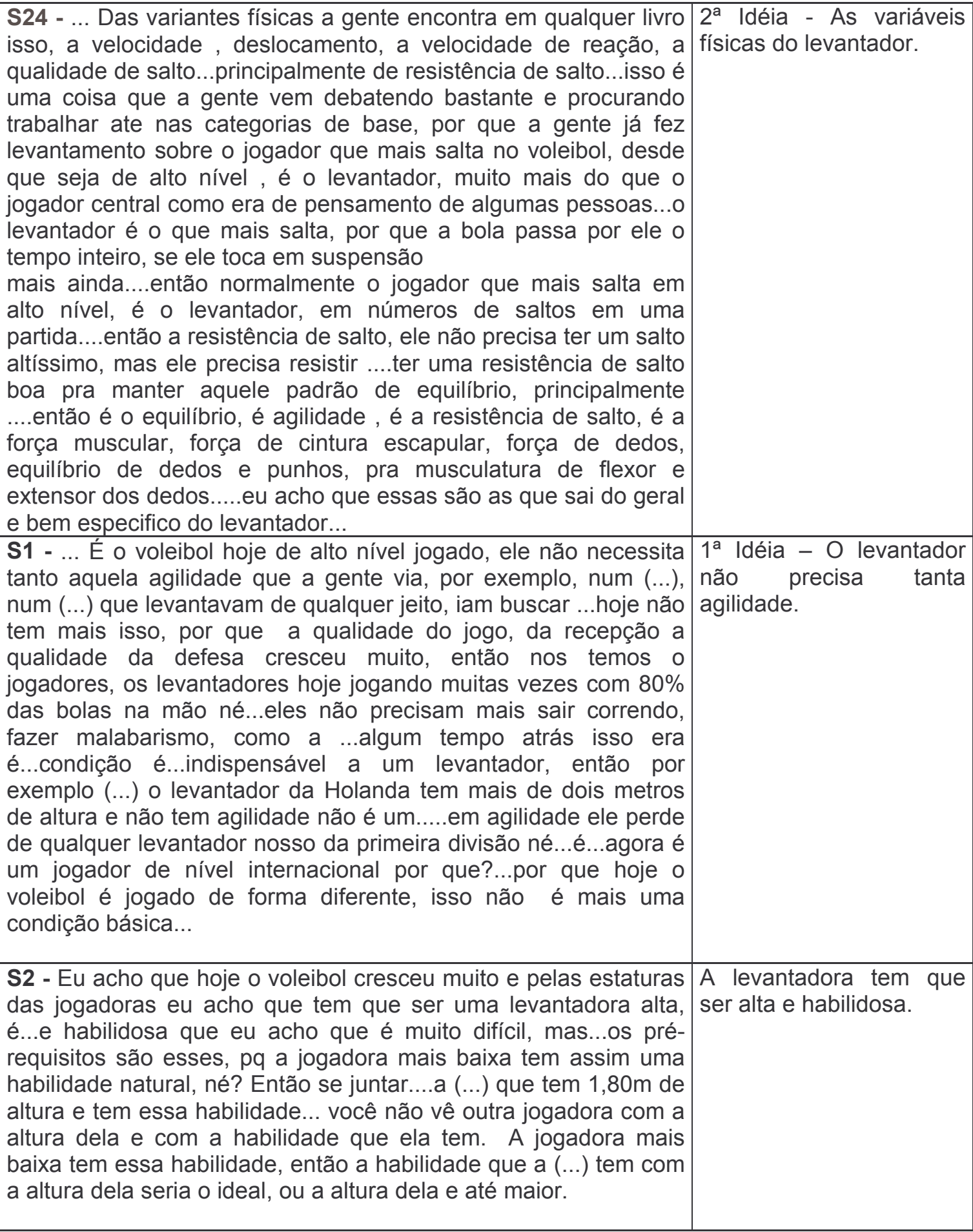

continua 
QUADRO 1 - Expressões Chave e as respectivas Idéias Centrais dos discursos emitidos (cont.)

S22 - ... Eu acho que com 25 anos ele ta madura, ele ta apto, Aos 25 anos o levantador até mais às vezes, você vê hoje em dia o nosso, ... o principal é a está maduro.

concentração né, o nível de concentração, o domínio, você tem que ter uma reação de poucos segundos, você tem que saber pra onde você vai distribuir uma bola, pra quem você vai levantar, o atacante que psicologicamente naquele momento ta bom, você tem que olhar o bloqueio adversário e tudo isso numa fração de segundos que você só passa a, a entender, a fazer isso com uma precisão depois dos 25 anos até mesmo a entender taticamente o que o seu treinador pede a você....

S6 - ... O aspecto físico hoje é muito importante, é ... hoje principalmente no voleibol feminino, com o crescimento do ataque internacional, a altura das jogadoras, hoje uma levantadora, ela tem que aí, uma ... Não precisa nem ser grande, mas ela tem que ter uma envergadura e um alcance alto é ... alto, num padrão alto. Acho que é a primeira coisa, porque senão você acaba .... por mais que ela seja habilidosa. Por mais que ela tenha todas as características de distribuição do jogo, é ... são três passagens ali que pro alto nível é... você acaba socando muito, ...

S3 - Bom, fisicamente, com certeza ter velocidade, estar magrinha, levantadora gordinha é muito difícil de chegar nas bolas, eu acho a questão física é muito importante, pra você é...pra você chegar com equilíbrio nas bolas, coisa que às vezes....até eu comentando com o (...) ....a levantadora dele até hoje - vou observar mais, que ela chega atrasada nas bolas, pro passe estourado ai a bola sai torta, ela tem que entrar mais de frente, então são coisas assim, que eu acho que são detalhes que a gente tem que consertar agora que está nessa idade do aprendizado ainda,...

S4 - A parte física acredito que hoje no alto nível, esta exigindo muito a altura,...

$1^{\text {a }}$ Idéia - Exigência do levantador na parte física.

S7 - Bom, hoje em dia como característica física eu acho que se encaixa um pouco como atacante. Levantadora antigamente era sempre a baixinha do time, tinha até um biótipo físico diferente das outras jogadoras. Hoje não, levantadora precisa ser tão alta quanto.... eu acho que no mínimo $1,80 \mathrm{~m}$ pra jogar em nível internacional. Sempre tão forte quanto às outras, porque ela precisa saltar, ela precisa bloquear. Hoje faz muita falta uma levantadora que não bloqueia. Ela precisa ser ágil na quadra, pra defender, pra correr atrás do passe. Acho que fisicamente hoje ela se enquadra muito como a atacante.... 
QUADRO 1 - Expressões Chave e as respectivas Idéias Centrais dos discursos emitidos (cont.)

S5 - ...antigamente quando se montava uma equipe não se fazia pela qualidade individual do jogador, qualidade técnica, então ,ou seja, o jogador com acima, o jogador novo ou uma jogadora nova que tinha uma estatura acima da mediana, ela já ia, já era colocada na posição de atacante, e muitas vezes um jogador mais alto, tinha habilidade pra ser levantador, mais ele nunca era recrutado, sempre quem seria recrutado, são jogadores mais baixos,e...

S9 - Primeiro lugar o individuo tem que se identificar, tem que gostar da função, segundo tem que ter agilidade, é... a mão boa, como a gente diz na gíria, né e percepção do jogo como um todo...tanto do que ta na sua quadra, do seu lado de quadra, como o do outro lado né e ai acho que está a maior dificuldade que a gente não tem pelo menos no nível em que eu trabalho....

S11 - ... Segundo é gostar de levantar. Precisa gostar, precisa, não sei se eu posso falar, um tesão imenso de levantar. ...

S4 - ... habilidade em manuseio com a bola e a visão tática que ele vai ter do é.... seu jogador, da sua equipe e da equipe adversária....

S12 - Primeiro, ter obediência e tática, sem obediência técnica e tática, o levantador ele se perde no jogo, muitas vezes você, você quer que o levantador tenha criatividade, mas se essa criatividade não for direcionada, não for direcionada pra aquilo que o jogo exige, o jogador pode se perder, capacidade de raciocínio rápido, acho que é importante e também agilidade de deslocamento, são as variáveis que eu acho que contam bastante para um levantador...

S11 - ... Terceiro, tem que ser extremamente inteligente. Quando falo em inteligência, bem, eu falo na inteligência da pessoa que mais ou menos $80 \%$ é nata. Porque hoje o que você tem como levantadora, ou você treina a menina repetitivamente 1.000 toques aqui, 1.000 toques atrás, 1.000 toques no fundo, 1.000 toques na frente, mas assim a inteligência dela vai ter momentos no jogo que vai faltar...

S13 - ... De fazer nos momentos certos, o jogo com mais risco, com menos risco. Então, ele tem que ser uma pessoa hoje com conhecimento tão grande, quanto o próprio treinador. $1^{a}$ Idéia - Antigamente se recrutava o jogador mais baixo para ser o levantador.

O indivíduo tem que se identificar com a posição de levantador. $2^{a}$ Idéia - Gostar de levantar.

$3^{a}$ Idéia - Exigência técnica do levantador.

O levantador precisa de obediência técnico-tática.

$3^{a} \quad$ Idéia - $\quad$ Ter
inteligência.

$2^{a}$ Idéia - O levantador tem que ter o conhecimento treinador. 
QUADRO 1 - Expressões Chave e as respectivas Idéias Centrais dos discursos emitidos (cont.)

S1 - ... é preciso hoje é....muito mais é...qualidade é...motoras né, $3^{\text {a }}$ Idéia $-\quad$ O que o de percepção, de antecipação, de conhecimento do ritmo do levantador precisa hoje jogo, do passe, é de visualização, de raciocínio tático, eu acho (tático).

que é muito mais isso do que é.....agilidade, do que habilidade no toque é...os levantadores Norte Americanos com exceção (...) é.....não são jogadores hábeis né...que a gente pode comparar ao (...), a um (...), a um (...) que são nossos melhores levantadores, mais é...dentro das características do voleibol atual eles se enquadram perfeitamente, por que tem um bom bloqueio, tem uma distribuição de jogo boa, né...é todas essas capacidades ai, qualidades que eu já citei, então hoje mudou um pouco...mudou um pouco, a gente tem que encarar dessa forma pra produzir levantadores capazes de se encaixar nesse novo...novo jogo.

S4 - ... a visão tática que ele vai ter do é.... seu jogador, da sua equipe e da equipe adversária...

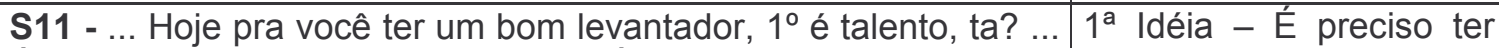
É uma coisa que eu acho assim: É a primeira coisa é você talento (ser criativo). conseguir detectar no meio de um monte de gente quem tem talento pra coisa, ta?... É isso que eu falo, são poucas as pessoas que têm esse talento até como técnico de bater o olho e virar e falar assim: olha, isso pode levantar. ... Hoje um grande levantador sabe na hora o que ele tem que fazer. Muitas vezes sem...... não todas as jogadas que você consegue fazer no treino, sempre tem uma ou duas dentro de campo que você não fez e naquela hora (carta na manga) exatamente. ...

S13 - Acho que o ponto principal hoje é uma análise que o $1^{\text {a }}$ Idéia - O levantador levantador tem que fazer, não só de aspectos técnicos, táticos, tem que conhecer o mas, principalmente psicológicos. É importante que o atleta hoje, atleta com quem joga. que o levantador conheça o atleta, inclusive que passe o que ele sente, né? Pra que em momentos decisivos do jogo ele possa saber quem é que ta mais preparado pra poder receber uma bola... E o levantador tem que ser uma pessoa especial, uma pessoa que realmente tenha a sensibilidade, tenha a sobriedade, né? ...

S15 - Acho que nossa posição...é uma posição assim muito ...é...ela exige muita assim...muita concentração acho que levantador tem que ser muito concentrado, observador e acho que...isso faz a diferença, a gente não pode ser um atleta assim que vibre demais, que pule demais por que a gente tem que estar concentrado o tempo inteiro, então essa vibração às vezes tira um pouco da concentração...mas acho que observar muito, ser muito observador acho que isso é importante pra você chegar num alto nível . 
QUADRO 1 - Expressões Chave e as respectivas Idéias Centrais dos discursos emitidos (cont.)

S14 - Bom, primeiro é o seguinte, eu acho que o levantador não tem tanto estímulo igual o atacante né...o maior estímulo que tem o voleibol é o ataque, então toda criança quer ser atacante. Raramente você pega criança pra ser levantadora, então depende do...da...dos técnicos que trabalham com essas atletas pra sabe... desenvolver isso ai, não adianta pega baixinho, se levantador, alto se atacante, isso dura três anos, depois a criança baixinha dificilmente ela joga, então acho que os técnicos têm que trabalhar com essa parte ai pra gente pegar um atleta caído do céu acho muito difícil, basta saber que o (...) antigamente era atacante e depois passou a ser levantador, (...) , ela era atacante e depois passou a ser levantadora, então acho que mais a parte do...do técnico cativar o atleta do que o atleta ser cativado, isso é um ponto de vista ... ,então o estímulo mais forte no voleibol é o ataque...

S19 - ... a levantadora é a alma do time né? pq todas as bolas passam pela mão da levantadora, então ela é que sabe o que vai fazer... a jogada que vai fazer, então eu acho que se ela não tiver é...é... um raciocínio um pouco mais rápido e melhor do que uma atacante...é ...bom eu acho que ela não tem condições de jogar lá fora ou mesmo de jogar grandes partidas aqui dentro do Brasil... a principal característica de um levantador é a inteligência, eu acho que um levantador que não é inteligente não consegue jogar jamais...não tem condições de jogar. Eu acho assim...que a gente fala muito de (...), a (...) além dela ser muito habilidosa, ela é extremamente inteligente, então..ela joga com aquela pessoa que tá rodando. Vamos supor, eu já joguei com ela na seleção e calhou de um jogo eu estar muito bem. Eu recebi 50 bolas e a segunda que recebeu, recebeu três. então ela joga ... ela usa a inteligência dela em função de quem estiver bem, quem tiver rodando ...você não vai esperar a (...) fazer jogadas mirabolantes de tá lá na ponta e ela inverter pra saída ou de um fundo. Ela sempre joga aquele jogo mais simples, não que seja simples, mas...é mais cadenciado, mas ela é extremamente inteligente por causa disso, e eu digo assim...é...a alma do time pq , a gente ...todas as atacantes precisam esperar pela levantadora pra fazer uma ação. Então a gente precisa sempre esperar por ela, e se...ela.. por exemplo, não tiver no jogo , não tiver bem naquele dia , não tem jogo, acabou o jogo, né? Pq não tem o que você fazer, não tem o que uma atacante resolver, pq ela não vai tocar na bola e sempre a bola vai passar pela levantadora. Eu acho por isso a levantadora é a alma do time. 
QUADRO 1 - Expressões Chave e as respectivas Idéias Centrais dos discursos emitidos (cont.)

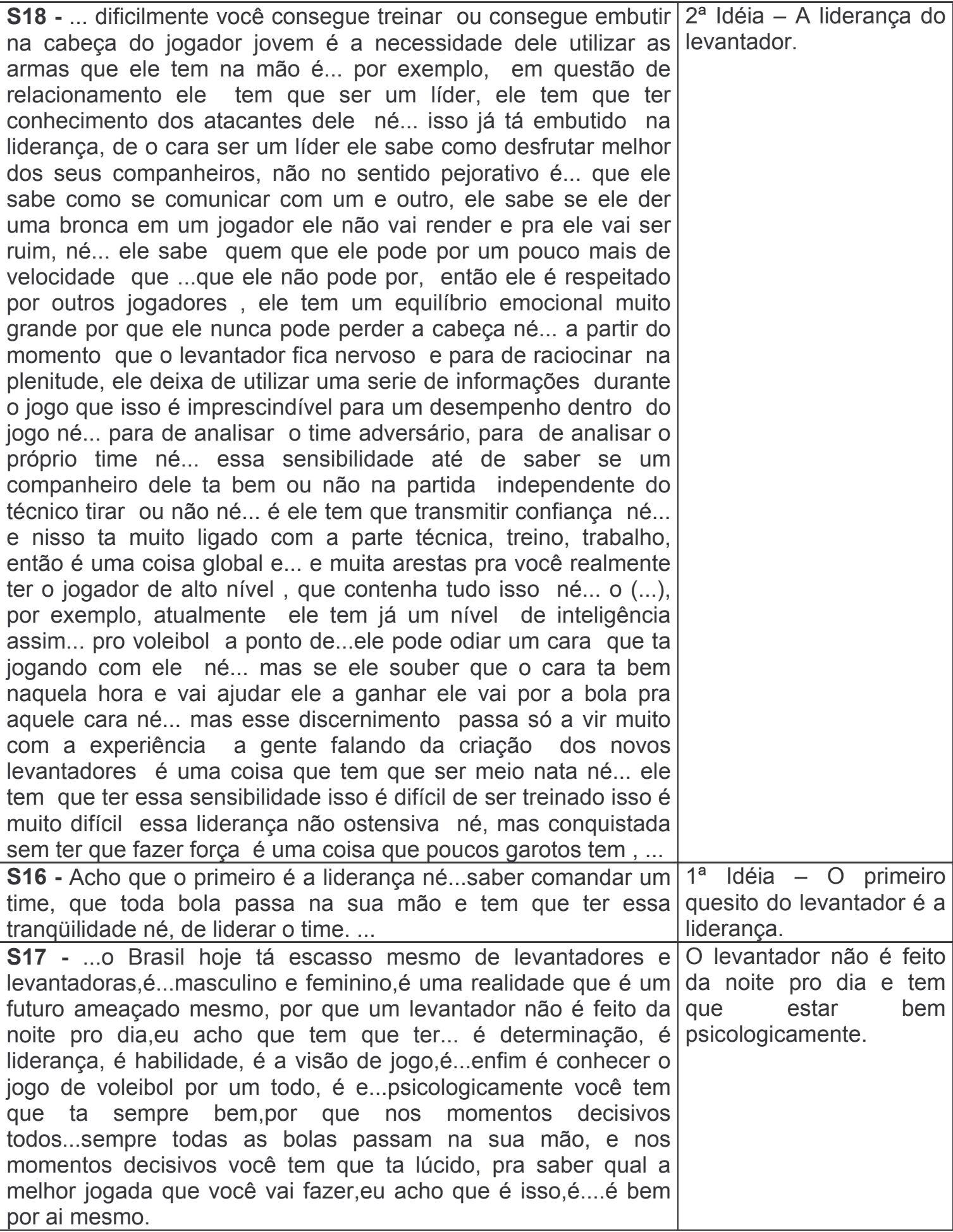


QUADRO 1 - Expressões Chave e as respectivas Idéias Centrais dos discursos emitidos (cont.)

\begin{abstract}
S20 - ...primeiro requisito num levantador tem que ser inteligente, inteligente eu digo, tem que ser uma pessoa tranqüila, tem uma ...tem que ser uma pessoa ou um atleta de raciocínio rápido e que assimile a ... o jogo em si, eu não simplesmente jogue a bola mecanicamente que é o que a gente vê, eu não vou dizer nomes, mais eu acho a (...) uma craque de bola, que sabe raciocinar durante o jogo e outras levantadoras no Pais, feminino que são bem treinadas, elas são bem treinadas, elas não sabem o que elas estão fazendo, me desculpe, mais essa é a minha opinião.
\end{abstract}

S21 - ...primeiro eu acho que ele tem que ser muito bom tecnicamente e segundo eu acho que ele tem que ter muita percepção. Eu acho que tem determinados momentos do jogo que ele tem que perceber quem é que ta melhor, quem é que tem que receber aquela bola, independente de qual bola seja. Eu acho que isso é o mais importante pro levantador... pq tem momento no jogo, por ex. 23 a 23 que ele tem que perceber quem é que ta melhor psicologicamente e com coragem pra decidir aquela bola. Ele não pode né? No 23 a 23 dar uma bola pra aquela pessoa que errou as três bolas anteriores ou que ele sentiu que não ta bem. Então...é um momento de decisão então eu acho que ele tem que perceber quem é que ta melhor naquele momento pra poder ganhar o jogo na verdade.

S7 - ...agora psicologicamente ela tem que ter muita paciência tem que saber ouvir muito, quando eu digo ouvir é... ouvir e não se influenciar por tudo, porque é nela que vem tudo, é o técnico que fala, as jogadoras falam. Então ela tem que ser rápida, ela tem que ouvir, filtrar o que serviu e o que não serviu, tem que passar. Ela tem que ter uma personalidade forte, porque ela tem que saber se impor. Eu acho que não é pra dizer, que não tem que ouvir, não tem que aceitar a opinião de ninguém, mas ela tem que saber se impor na quadra. Ela tem que mandar na quadra, assim como o técnico comanda fora, ela tem que ter esse comando dentro da quadra. Eu acho que é a característica $n^{\circ} 1$, falando do lado psicológico. Saber se impor e comandar o time. E uma outra, acho que tem que ser inteligente, porque ela tem que... existe uma jogadora que não ta muito bem no dia. Tem que saber a hora de falar, ela tem que saber aquela que é melhor você deixar quieta. Tem que saber quem precisa de um empurrão, uma pegada, uma coisa mais positiva. Tem jogadora que você não pode falar em um tom mais agressivo porque sente, e outra não. Então tem que ter tudo isso, tem que saber um pouquinho de cada jogadora que ta jogando do seu lado.
O primeiro requisito do

levantador é

inteligência.

$a$

O levantador tem que ter muita percepção.

$\begin{array}{rrrr}2^{a} & \text { Idéia } & - & \text { Lado } \\ \text { psicológico } & & \text { da }\end{array}$

levantadora. 
QUADRO 1 - Expressões Chave e as respectivas Idéias Centrais dos discursos emitidos (cont.)

\begin{tabular}{|c|c|}
\hline $\begin{array}{l}\text { S23 - ... O levantador realmente tem que estar com a cabeça } \\
\text { ligado, pensando durante o tempo todo do jogo, entender o que } \\
\text { está sendo feito, o que tem que ser feito, a estratégia que tem } \\
\text { que ser feita, ah. Pra jogar contra o adversário, então o lado } \\
\text { psicológico do levantador é muito mais importante do que o lado } \\
\text { físico. }\end{array}$ & $\begin{array}{l}\text { O psicológico } \text { do } \\
\text { levantador é mais } \\
\text { importante do que o } \\
\text { físico. }\end{array}$ \\
\hline $\begin{array}{l}\text { S4 - ... a liderança, ...na psicológica, tem que ser uma pessoa } \\
\text { muito inteligente que tenha uma visão é...ampla, né?..é...ter uma } \\
\text { percepção muito boa pra que ele posso distribuir é...as bolas } \\
\text { devidas pra seus atacantes. }\end{array}$ & $\begin{array}{lr}2^{a} \quad \text { Idéia } & - \text { Exigência } \\
\text { psicológica } & \text { do } \\
\text { levantador. } & \end{array}$ \\
\hline
\end{tabular}

8

DISCUSSÃO

Como descrito anteriormente, os dados discursivos fornecidos pelos sujeitos foram inseridos no software QualiQuantiSoft e organizados sob a ótica das representações sociais, estruturando-se o Discurso do Sujeito Coletivo (DSC) e preparados sob a forma de duas figuras metodológicas: Expressão-Chave $(E C H)$ e Idéia Central (IC), conseguidos a partir de trechos das respostas emitidos pelos sujeitos entrevistados, as quais permitiram a identificação de palavras e expressões. Posteriormente, os discursos foram categorizados segundo similaridades ou equivalências, ou seja, pelo fato de conterem a mesma idéia, como descritos a seguir:

5. Categoria A - Aspectos Físicos - Letra A (QUADRO 2);

6. Categoria B - Aspectos Técnicos - Letra B (QUADRO 4);

7. Categoria C - Aspectos Táticos - Letra C (QUADRO 6);

8. Categoria D - Aspectos Psicológicos - Letra D (QUADRO 8).

Analisando os discursos de um conjunto de indivíduos submetidos a uma mesma circunstância, foi possível resgatar e identificar as idéias, opiniões e sentimentos para estruturar os modos de pensar e interpretar dos entrevistados frente ao perfil dos levantadores (DSC) nos QUADROS 3, 5, 7 e 9. 
QUADRO 2 - Categoria A - Expressões Chave e Idéias Centrais dos Aspectos Físicos

\begin{tabular}{|c|c|}
\hline Expressões Chave & Idéias Centrais \\
\hline $\begin{array}{l}\text { S1 - ... É o voleibol hoje de alto nível jogado, ele não necessita } \\
\text { tanto aquela agilidade que a gente via, por exemplo, num (...), } \\
\text { num (...) que levantavam de qualquer jeito, iam buscar ...hoje não } \\
\text { tem mais isso, por que a qualidade do jogo, da recepção a } \\
\text { qualidade da defesa cresceu muito, então nos temos o } \\
\text { jogadores, os levantadores hoje jogando muitas vezes com } 80 \% \\
\text { das bolas na mão né...eles não precisam mais sair correndo, } \\
\text { fazer malabarismo, como a ...algum tempo atrás isso era } \\
\text { é...condição é...indispensável a um levantador, então por } \\
\text { exemplo (...) o levantador da Holanda tem mais de dois metros } \\
\text { de altura e não tem agilidade não é um....em agilidade ele perde } \\
\text { de qualquer levantador nosso da primeira divisão né...é...agora é } \\
\text { um jogador de nível internacional por que?...por que hoje o } \\
\text { voleibol é jogado de forma diferente, isso não é mais uma } \\
\text { condição básica... }\end{array}$ & 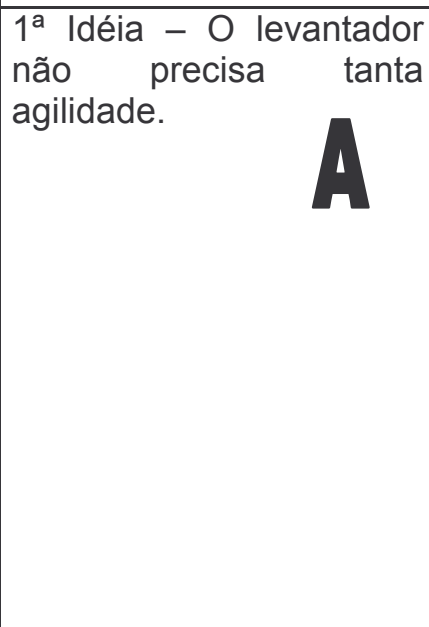 \\
\hline $\begin{array}{l}\text { S24 - ... Das variantes físicas a gente encontra em qualquer livro } \\
\text { isso, a velocidade , deslocamento, a velocidade de reação, a } \\
\text { qualidade de salto...principalmente de resistência de salto...isso é } \\
\text { uma coisa que a gente vem debatendo bastante e procurando } \\
\text { trabalhar ate nas categorias de base, por que a gente já fez } \\
\text { levantamento sobre o jogador que mais salta no voleibol, desde } \\
\text { que seja de alto nível, é o levantador, muito mais do que o } \\
\text { jogador central como era de pensamento de algumas pessoas...o } \\
\text { levantador é o que mais salta, por que a bola passa por ele o } \\
\text { tempo inteiro, se ele toca em suspensão } \\
\text { mais ainda....então normalmente o jogador que mais salta em } \\
\text { alto nível, é o levantador, em números de saltos em uma } \\
\text { partida....então a resistência de salto, ele não precisa ter um salto } \\
\text { altíssimo, mas ele precisa resistir ....ter uma resistência de salto } \\
\text { boa pra manter aquele padrão de equilíbrio, principalmente } \\
\text {....então é o equilíbrio, é agilidade, é a resistência de salto, é a } \\
\text { força muscular, força de cintura escapular, força de dedos, } \\
\text { equilíbrio de dedos e punhos, pra musculatura de flexor e } \\
\text { extensor dos dedos....eu acho que essas são as que sai do geral } \\
\text { e bem especifico do levantador... }\end{array}$ & $\begin{array}{l}2^{a} \text { Idéia - As variáveis } \\
\text { físicas do levantador. }\end{array}$ \\
\hline $\begin{array}{l}\text { S2 - Eu acho que hoje o voleibol cresceu muito e pelas estaturas } \\
\text { das jogadoras eu acho que tem que ser uma levantadora alta, } \\
\text { é...e habilidosa que eu acho que é muito difícil, mas...os pré- } \\
\text { requisitos são esses, pq a jogadora mais baixa tem assim uma } \\
\text { habilidade natural, né? Então se juntar.... (...) que tem } 1,80 \mathrm{~m} \text { de } \\
\text { altura e tem essa habilidade... você não vê outra jogadora com a } \\
\text { altura dela e com a habilidade que ela tem. A jogadora mais } \\
\text { baixa tem essa habilidade, então a habilidade que a (...) tem com } \\
\text { a altura dela seria o ideal, ou a altura dela e até maior. }\end{array}$ & $\begin{array}{l}\text { A levantadora tem que } \\
\text { ser alta e habilidosa. }\end{array}$ \\
\hline
\end{tabular}


QUADRO 2 - Categoria A - Expressões Chave e Idéias Centrais dos Aspectos Físicos (cont.)

S6 - ... O aspecto físico hoje é muito importante, é ... hoje $1^{\text {a }}$ Idéia - O aspecto físico principalmente no voleibol feminino, com o crescimento do da levantadora é muito ataque internacional, a altura das jogadoras, hoje uma importante.

levantadora, ela tem que aí, uma ... Não precisa nem ser grande, mas ela tem que ter uma envergadura e um alcance alto é ... alto, num padrão alto. Acho que é a primeira coisa, porque senão você acaba .... por mais que ela seja habilidosa. Por mais que ela tenha todas as características de distribuição do jogo, é ... são três passagens ali que pro alto nível é... você acaba socando muito,...

S3 - Bom, fisicamente, com certeza ter velocidade, estar magrinha, levantadora gordinha é muito difícil de chegar nas bolas, eu acho a questão física é muito importante, pra você é...pra você chegar com equilíbrio nas bolas, coisa que às vezes...até eu comentando com o (...) ....a levantadora dele até hoje - vou observar mais, que ela chega atrasada nas bolas, pro passe estourado ai a bola sai torta, ela tem que entrar mais de frente, então são coisas assim, que eu acho que são detalhes que a gente tem que consertar agora que está nessa idade do aprendizado ainda,...

S7 - Bom, hoje em dia como característica física eu acho que se encaixa um pouco como atacante. Levantadora antigamente era sempre a baixinha do time, tinha até um biótipo físico diferente das outras jogadoras. Hoje não, levantadora precisa ser tão alta quanto.... eu acho que no mínimo $1,80 \mathrm{~m}$ pra jogar em nível internacional. Sempre tão forte quanto às outras, porque ela precisa saltar, ela precisa bloquear. Hoje faz muita falta uma levantadora que não bloqueia. Ela precisa ser ágil na quadra, pra defender, pra correr atrás do passe. Acho que fisicamente hoje ela se enquadra muito como a atacante....

S8 - ... eu acho, que o voleibol brasileiro, pela versatilidade que o jogo..... pela dinâmica do jogo, eu acho que ele necessita de grande ... de jogadoras altas, especialmente que tenha o domínio da quadra, do controle do jogo, mesmo, em si, porque para o levantador, principalmente, feminino, ela é fundamental, ela dá o ritmo, ela dá o padrão do jogo e os últimos 10 anos aí a gente vê que o time que tinha a (...) ou a (...) é que eram campeãs da Superliga, com exceção da (...) que eu acho que é, depois das 2, a terceira grande levantadora do Brasil, assim, uma jogadora habilidosa, né? $\mathrm{E}$ grande, então, ela está adequada a esses padrões, né? Então eu penso nisso, a jogadora tem que ter conhecimento, realmente, do que se passa dentro da quadra, acho que é o principal, é precisão, né? Técnica, pra que ela possa ditar o ritmo do jogo.

$1^{a}$ Idéia - A característica física da levantadora é igual a da atacante.

$2^{a}$ Idéia - Levantadoras altas com domínio de quadra.

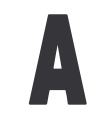

continua 
QUADRO 2 - Categoria A - Expressões Chave e Idéias Centrais dos Aspectos Físicos (cont.)

\begin{tabular}{|c|c|}
\hline $\begin{array}{l}\text { S5 - ... antigamente quando se montava uma equipe não se fazia } \\
\text { pela qualidade individual do jogador, qualidade técnica, então ,ou } \\
\text { seja, o jogador com acima, o jogador novo ou uma jogadora } \\
\text { nova que tinha uma estatura acima da mediana, ela já ia, já era } \\
\text { colocada na posição de atacante, e muitas vezes um jogador } \\
\text { mais alto, tinha habilidade pra ser levantador, mais ele nunca era } \\
\text { recrutado, sempre quem seria recrutado, são jogadores mais } \\
\text { baixos,e... }\end{array}$ & $\begin{array}{l}1^{\text {a }} \text { Idéia - Antigamente se } \\
\text { recrutava o jogador mais } \\
\text { baixo para ser o } \\
\text { levantador. }\end{array}$ \\
\hline $\begin{array}{l}\text { S4 - A parte física acredito que hoje no alto nível, esta exigindo } \\
\text { muito a altura,... }\end{array}$ & $\begin{array}{l}1^{\text {a }} \text { Idéia - Exigência do } \\
\text { levantador na parte } \\
\text { física. }\end{array}$ \\
\hline
\end{tabular}

QUADRO 3 - Discurso do Sujeito Coletivo (DSC) da Categoria A (Aspectos Físicos)

1. Para você, quais seriam as variáveis que uma levantadora deve ter para ser uma atleta de alto rendimento e chegar a uma seleção nacional?

\section{DSC DA CATEGORIA - A}

Eu acho, que o voleibol brasileiro, pela versatilidade que o jogo..... pela dinâmica do jogo, eu acho que ele necessita de grande ... de jogadoras altas, especialmente que tenha o domínio da quadra, do controle do jogo, mesmo, em si, porque para o levantador, principalmente, feminino, ela é fundamental, ela dá o ritmo, ela dá o padrão do jogo e os últimos 10 anos aí a gente vê que o time que tinha a (...) ou a (...) é que eram campeãs da Superliga, com exceção da (...) que eu acho que é, depois das duas, a terceira grande levantadora do Brasil, assim, uma jogadora habilidosa, né? E grande, então, ela está adequada a esses padrões, né? Também não necessita tanto aquela agilidade que a gente via por exemplo num (...), num (...) que levantavam de qualquer jeito, iam buscar ....hoje não tem mais isso, por que a qualidade do jogo, da recepção a qualidade da defesa cresceu muito, então nos temos o jogadores, os levantadores hoje jogando muitas vezes com $80 \%$ das bolas na mão né...eles não precisam mais sair correndo, fazer malabarismo, como a ...algum tempo atrás isso era é...condição é....indispensável a um levantador, então por exemplo o (...) o levantador da Holanda tem mais de dois metros de altura e não 
tem agilidade não é um....em agilidade ele perde de qualquer levantador nosso da primeira divisão né...é....agora é um jogador de nível internacional por que?..por que hoje o voleibol é jogado de forma diferente, isso não é mais uma condição básica.

O voleibol cresceu muito e pelas estaturas das jogadoras eu acho que tem que ser uma levantadora alta, é...e habilidosa que eu acho que é muito difícil mas...os pré requisitos são esses, por que as jogadoras mais baixas tem assim uma habilidade natural, né? Então se juntar.... a (...) que tem 1,80m de altura e tem essa habilidade... você não vê outra jogadora com a altura dela e com a habilidade que ela tem. As jogadoras mais baixas têm essa habilidade, então a habilidade que a (...) tem com a altura dela seria o ideal, ou a altura dela e até maior.

Antigamente quando se montava uma equipe não se fazia pela qualidade individual do jogador, qualidade técnica, então ou seja o jogador .... o jogador novo ou uma jogadora nova que tinha uma estatura acima da mediana, ela já ia, já era colocada na posição de atacante, e muitas vezes um jogador mais alto, tinha habilidade pra ser levantador, mais ele nunca era recrutado, sempre quem seria recrutado, são jogadores mais baixos, e... o aspecto físico hoje é muito importante, é ... hoje principalmente no voleibol feminino, com o crescimento do ataque internacional, a altura das jogadoras, hoje uma levantadora, ela tem que aí, uma ... Não precisa nem ser grande, mas ela tem que ter uma envergadura e um alcance alto, é ... alto, num padrão alto. Acho que é a primeira coisa, porque senão você acaba .... por mais que ela seja habilidosa. Por mais que ela tenha todas as características de distribuição do jogo, é ... são três passagens ali que pro alto nível é... você acaba socando muito,... eu acho que se encaixa um pouco como atacante. Levantadora antigamente era sempre a baixinha do time, tinha até um biótipo físico diferente das outras jogadoras. Hoje não, levantadora precisa ser tão alta quanto.... eu acho que no mínimo 1,80m pra jogar em nível internacional. Sempre tão forte quanto as outras, porque ela precisa saltar, ela precisa bloquear. Hoje faz muita falta uma levantadora que não bloqueia. Ela precisa ser ágil na quadra, pra defender, pra correr atrás do passe. Acho que fisicamente hoje ela se enquadra muito como a atacante....

Das variantes físicas a gente encontra em qualquer livro isso, a velocidade, deslocamento, a velocidade de reação, a qualidade de salto...principalmente de 
resistência de salto...isso é uma coisa que a gente vem debatendo bastante e procurando trabalhar ate nas categorias de base, por que a gente já fez levantamento sobre o jogador que mais salta no voleibol, desde que seja de alto nível , é o levantador, muito mais do que o jogador central como era de pensamento de algumas pessoas...o levantador é o que mais salta, por que a bola passa por ele o tempo inteiro, se ele toca em suspensão mais ainda....então normalmente o jogador que mais salta em alto nível, é o levantador, em números de saltos em uma partida....então a resistência de salto, ele não precisa ter um salto altíssimo, mas ele precisa resistir ....ter uma resistência de salto boa pra manter aquele padrão de equilíbrio, principalmente ....então é o equilíbrio, é agilidade , é a resistência de salto, é a força muscular, força de cintura escapular, força de dedos, equilíbrio de dedos e punhos, pra musculatura de flexor e extensor dos dedos.....eu acho que essas são as que sai do geral e bem especifico do levantador.

QUADRO 4 - Categoria B - Expressões Chave e Idéias Centrais dos Aspectos Técnicos

\begin{tabular}{|c|c|}
\hline Expressões Chave & Idéia Central \\
\hline $\begin{array}{l}\text { S10 - .... as jogadoras que foram especializadas desde de } \\
\text { pequenininha como levantadora não são as jogadoras que estão } \\
\text { é....dando rendimento entrando na seleção, com exceção da (...) } \\
\text { que foi levantadora desde mirim, as outras a gente sempre tem } \\
\text { jogadoras que foram atacantes, então eu acho isso já uma } \\
\text { situação meio delicada,.... }\end{array}$ & $\begin{array}{l}2^{\mathrm{a}} \text { Idéia - As jogadoras } \\
\text { que foram especializadas } \\
\text { desde pequenas não } \\
\text { rendem. }\end{array}$ \\
\hline $\begin{array}{l}\text { S4 - ... habilidade em manuseio com a bola e a visão tática que } \\
\text { ele vai ter do é.... seu jogador, da sua equipe e da equipe } \\
\text { adversária.... }\end{array}$ & $\begin{array}{l}3^{a} \text { Idéia - Exigência } \\
\text { técnica do levantador. }\end{array}$ \\
\hline
\end{tabular}

continua 
QUADRO 4 - $\underline{\text { Categoria B - Expressões Chave e Idéias Centrais dos Aspectos Técnicos (cont.) }}$

S24 - ... A qualidade seria a variação, o domínio de todos os tipos de variações de toque e de manchete, por que varias situações o jogador não tem possibilidade de chegar de toque e ele tem que ser um bom levantador também de manchete, ter um controle da manchete, o que a gente observa muito, é que o jogador de alto nível, sempre é o melhor defensor da equipe, hoje com a existência do libero caiu um pouco, mas normalmente....você vê , a (...) já ganhou varias vezes como melhor defensora da Superliga e o (...) também, sempre os levantadores estão à frente, por que eles tem uma percepção, uma análise melhor de trajetória de bola, uma análise melhor do atacante pra se posicionar...então essa antecipação ....que também na parte física eu esqueci de colocar ....que é fundamental pra um levantador, essa antecipação da ação que vai acontecer, ou antes, ou depois dele.

S9 - Primeiro lugar o individuo tem que se identificar, tem que gostar da função, segundo tem que ter agilidade, é... a mão boa, como a gente diz na gíria, né e percepção do jogo como um todo...tanto do que ta na sua quadra, do seu lado de quadra, como o do outro lado né e ai acho que está a maior dificuldade que a gente não tem pelo menos no nível em que eu trabalho....

S4 - ... habilidade em manuseio com a bola e a visão tática que ele vai ter do é.... seu jogador, da sua equipe e da equipe adversária.... $3^{a}$ Idéia - As qualidades técnicas do levantador.
O indivíduo tem que se identificar com a posição de levantador. $3^{a}$ Idéia - Exigência técnica do levantador.

QUADRO 5 - Discurso do Sujeito Coletivo (DSC) da Categoria B (Aspectos Técnicos)

1. Para você, quais seriam as variáveis que uma levantadora deve ter para ser uma atleta de alto rendimento e chegar a uma seleção nacional?

\section{DSC DA CATEGORIA - B}

Primeiro lugar o individuo tem que se identificar, tem que gostar de levantar. Precisa gostar, precisa, não sei se eu posso falar, um tesão imenso de levantar. Segundo, é... a mão boa, como a gente diz na gíria, né? ... habilidade em manuseio 
com a bola, e percepção do jogo como um todo...tanto do que tá na sua quadra, do seu lado de quadra, como o do outro lado né? e aí acho que está a maior dificuldade que a gente não tem pelo menos no nível em que eu trabalho. As jogadoras que foram especializadas desde de pequenininha como levantadora não são as jogadoras que estão é....dando rendimento entrando na seleção, com exceção da (...) que foi levantadora desde mirim, as outras a gente sempre foram atacantes, então eu acho isso já uma situação meio delicada.

A qualidade seria a variação, o domínio de todos os tipos de variações de toque e de manchete, por que varias situações o jogador não tem possibilidade de chegar de toque e ele tem que ser um bom levantador também de manchete, ter um controle da manchete, o que a gente observa muito, é que o jogador de alto nível, sempre é o melhor defensor da equipe, hoje com a existência do líbero caiu um pouco, mas normalmente....você vê , a (...) já ganhou varias vezes como melhor defensora da Superliga e o (...) também, sempre os levantadores estão a frente, por que eles tem um percepção, uma análise melhor de trajetória de bola, uma análise melhor do atacante pra se posicionar...então essa antecipação ....que também na parte física eu esqueci de colocar ....que é fundamental pra um levantador, essa antecipação da ação que vai acontecer, ou antes ou depois dele.

QUADRO 6 - $\underline{\text { Categoria C - Expressões Chave e Idéias Centrais dos Aspectos Táticos }}$

\begin{tabular}{|l|l|}
\hline \multicolumn{1}{|c|}{ Expressões Chave } & \multicolumn{1}{|c|}{ Idéia Central } \\
\hline $\begin{array}{l}\text { S4 - ... a visão tática que ele vai ter do é.... seu jogador, da sua } \\
\text { equipe e da equipe adversária... }\end{array}$ & $\begin{array}{l}4^{\text {a }} \text { Idéia - Exigência } \\
\text { tática do levantador }\end{array}$ \\
\hline $\begin{array}{l}\text { S13 - ... De fazer nos momentos certos, o jogo com mais risco, } \\
\text { com menos risco. Então, ele tem que ser uma pessoa hoje com } \\
\text { conhecimento tão grande, quanto o próprio treinador. }\end{array}$ & $\begin{array}{l}2^{\mathrm{a}} \text { Idéia - O levantador } \\
\text { tem que ter o } \\
\text { conhecimento do } \\
\text { treinador. }\end{array}$ \\
\hline
\end{tabular}


QUADRO 6 - Categoria C - Expressões Chave e Idéias Centrais dos Aspectos Táticos (cont.)

\begin{tabular}{|c|c|}
\hline $\begin{array}{l}\text { S5 - ...característica técnica muito boa e daí com o } \\
\text { amadurecimento taticamente ele vai melhorando muito ai isso ... } \\
\text { nós temos hoje, tanto no feminino, como no masculino jogadoras } \\
\text { que tem uma dedicação e tem uma disciplina tática muito boa, } \\
\text { mais o aspecto técnico inicial, de discernimento de jogo e malícia } \\
\text { de jogo, realmente diminuiu, então taticamente as jogadoras são } \\
\text { mais obedientes, elas procuram observar mais o jogo, e tal etc... } \\
\text { agora técnica pura, de levantador com uma certa estatura } \\
\text { mediana e que se destaque, e tenha realmente é...malandragem } \\
\text { no bom sentido do jogo, ta faltando mais,... }\end{array}$ & $\begin{array}{l}2^{\text {a }} \text { Idéia - } \\
\text { Amadurecimento tático } \\
\text { do levantador }\end{array}$ \\
\hline $\begin{array}{l}\text { S12 - Primeiro, ter obediência e tática, sem obediência técnica e } \\
\text { tática, o levantador ele se perde no jogo, muitas vezes você, } \\
\text { você quer que o levantador tenha criatividade, mas se essa } \\
\text { criatividade não for direcionada, não for direcionada pra aquilo } \\
\text { que o jogo exige, o jogador pode se perder, capacidade de } \\
\text { raciocínio rápido, acho que é importante e também agilidade de } \\
\text { deslocamento, são as variáveis que eu acho que contam } \\
\text { bastante para um levantador... }\end{array}$ & $\begin{array}{l}\text { O levantador precisa de } \\
\text { obediência técnico-tática. }\end{array}$ \\
\hline $\begin{array}{l}\text { S13 - ... De fazer nos momentos certos, o jogo com mais risco, } \\
\text { com menos risco. Então, ele tem que ser uma pessoa hoje com } \\
\text { conhecimento tão grande, quanto o próprio treinador. }\end{array}$ & $\begin{array}{l}2^{\text {a }} \text { Idéia - O levantador } \\
\text { tem que ter o } \\
\text { conhecimento do } \\
\text { treinador. }\end{array}$ \\
\hline $\begin{array}{l}\text { S1 - ... é preciso hoje é.....muito mais é...qualidade é...motoras né, } \\
\text { de percepção, de antecipação, de conhecimento do ritmo do } \\
\text { jogo, do passe, é de visualização, de raciocínio tático, eu acho } \\
\text { que é muito mais isso do que é....agilidade, do que habilidade no } \\
\text { toque é...os levantadores Norte Americanos com exceção (...) } \\
\text { é......não são jogadores hábeis né...que a gente pode comparar } \\
\text { ao (...), a um (...), a um (...) que são nossos melhores } \\
\text { levantadores, mais é...dentro das características do voleibol atual } \\
\text { eles se enquadram perfeitamente, por que tem um bom bloqueio, } \\
\text { tem uma distribuição de jogo boa, né...é todas essas } \\
\text { capacidades ai, qualidades que eu já citei, então hoje mudou um } \\
\text { pouco...mudou um pouco, a gente tem que encarar dessa forma } \\
\text { pra produzir levantadores capazes de se encaixar nesse } \\
\text { novo...novo jogo. }\end{array}$ & $\begin{array}{l}3^{\text {a }} \text { Idéia - O que o } \\
\text { levantador precisa hoje } \\
\text { (tático). }\end{array}$ \\
\hline
\end{tabular}


QUADRO 7 - Discurso do Sujeito Coletivo (DSC) da Categoria C (Aspectos Táticos)

1. Para você, quais seriam as variáveis que uma levantadora deve ter para ser uma atleta de alto rendimento e chegar a uma seleção nacional?

\section{DSC DA CATEGORIA - C}

Primeiro, ter obediência e tática, a visão tática que ele vai ter do é.... seu jogador, da sua equipe e da equipe adversária. Sem obediência técnico e tática, o levantador ele se perde no jogo, muitas vezes você, você quer que o levantador tenha criatividade, mas se essa criatividade não for direcionada, não for direcionada pra aquilo que o jogo exige, o jogador pode se perder, capacidade de raciocínio rápido, acho que é importante, que eu acho que contam bastante para um levantador.

Tem que ser extremamente inteligente. Quando falo em inteligência, bem, eu falo na inteligência da pessoa que mais ou menos $80 \%$ é nata. Porque hoje o que você tem como levantadora, ou você treina a menina repetitivamente 1.000 toques aqui, 1.000 toques atrás, 1.000 toques no fundo, 1.000 toques na frente, mas assim a inteligência dela vai ter momentos no jogo que vai faltar.

É preciso hoje é....muito mais é...qualidade é... né? de percepção, de antecipação, de conhecimento do ritmo do jogo, do passe, é de visualização, de raciocínio tático, de fazer nos momentos certos, o jogo com mais risco, com menos risco. Então, ele tem que ser uma pessoa hoje com conhecimento tão grande, quanto o próprio treinador. Eu acho que é muito mais isso do que é....agilidade, do que habilidade no toque é...os levantadores Norte Americanos com exceção (...) é.....não são jogadores hábeis né...que a gente pode comparar ao (...), a um (...), a um (...) que são nossos melhores levantadores, mais é...dentro das características do voleibol atual eles se enquadram perfeitamente, por que tem um bom bloqueio, tem uma distribuição de jogo boa, né...é todas essas capacidades ai, qualidades que eu já citei, então hoje mudou um pouco...mudou um pouco, a gente tem que encarar dessa forma pra produzir levantadores capazes de se encaixar nesse novo...novo jogo. 
Com.característica técnica muito boa e daí com o amadurecimento tático ele vai melhorando muito isso. Nós temos hoje, tanto no feminino, como no masculino jogadoras que tem uma dedicação e tem uma disciplina tática muito boa, mais o aspecto técnico inicial, de discernimento de jogo e malicia de jogo, realmente diminuiu, então taticamente as jogadoras são mais obedientes, elas procuram observar mais o jogo, e tal etc...agora técnica pura, de levantador com uma certa estatura mediana e que se destaque, e tenha realmente é...malandragem no bom sentido do jogo, tá faltando mais.

QUADRO 8 - Categoria D - Expressões Chave e Idéias Centrais dos Aspectos Psicológicos

\begin{tabular}{|c|c|}
\hline Expressões Chave & Idéia Central \\
\hline $\begin{array}{l}\text { S8 - Bem, eu acredito primeiro é no equilíbrio né? Equilíbrio } \\
\text { emocional é.... conhecimento de jogo, né? ... Então, a (...) é uma } \\
\text { menina que foi uma jogadora que sempre teve muita liderança, } \\
\text { que eu acho fundamental, conhecimento de jogo, é ..... equilíbrio, } \\
\text { lógico. Equilíbrio quando eu falo é.... se mantém muito } \\
\text { equilibrada. Todas elas já convivi, com essas jogadoras todas aí, } \\
\text { de perto. Todas elas têm seu momento de desequilíbrio, mas a } \\
\text { (...) se mantém por mais tempo em equilíbrio, precisão, né? } \\
\text { Técnica. }\end{array}$ & $\begin{array}{l}\text { 1a Idéia - Equilíbrio } \\
\text { emocional do levantador. }\end{array}$ \\
\hline $\begin{array}{l}\text { S6 - ... eu costumo falar sobre levantadora, gosto muito do } \\
\text { aspecto emocional da levantadora né? Acho que a levantadora } \\
\text { tem que ser uma líder, ela tem que ter uma liderança positiva em } \\
\text { relação às atacantes... então eu gosto muito de puxar nas } \\
\text { minhas levantadoras, isso aqui, essa liderança e esse desafio,... } \\
\text { Então a levantadora tem que ser forte, ela tem que ter } \\
\text { perseverança tem que ser dedicada tem que ser a primeira a } \\
\text { chegar no treino, a última a sair, tem que estar entrosada com o } \\
\text { técnico, em todo o esquema tático, tanto na sua equipe quanto } \\
\text { das outras equipes. Quais são os pontos mais fortes da sua } \\
\text { equipe, e juntos traçar isso no começo da temporada, junto com } \\
\text { o seu técnico e a cada jogo estudar e ver o que é que a gente } \\
\text { pode fazer em relação à equipe adversária, mas principalmente } \\
\text { ter uma liderança em cima das atacantes, pra que as atacantes } \\
\text { não fujam das responsabilidades, colocando sempre a culpa nas } \\
\text { levantadoras. }\end{array}$ & $\begin{array}{l}2^{a} \text { Idéia - A levantadora } \\
\text { tem que ser uma líder. }\end{array}$ \\
\hline
\end{tabular}


QUADRO 8 - Categoria D - Expressões Chave e Idéias Centrais dos Aspectos Psicológicos (cont.)

S24 - Olha... eu acho que o principal de um levantador...na parte psicológica...por que às vezes...muitas vezes quando tem deficiência física e deficiência técnica, ele consegue fazer o jogo pelo controle emocional dele e pelo controle que ele tem sobre a avaliação que ele faz dos companheiros de jogo dele...eu vou falar mais em termo de feminino por que é onde eu mais trabalho...então eu entendo que as variáveis psicológicas do controle emocional a observação e a facilidade de analise do colega...qual momento eu posso usar esse jogador, qual o momento eu não posso usar esse jogador, a identificação de como o jogador reage com determinado tipo de bola ...qual é a maior eficiência dele qual a maior deficiência dele, como se dirigir com o jogador que ela vai levantar a bola, se ela deve ser agressiva, se ela deve ser carinhosa, se ela deve ser atenciosa...então eu acho que esse é um componente fundamental pra uma levantadora de altíssimo nível....

S11 - ... Segundo é gostar de levantar. Precisa gostar, precisa, não sei se eu posso falar,

um tesão imenso de levantar. ...

$\mathbf{S 1 1}-\ldots$ Hoje pra você ter um bom levantador, $1^{\circ}$ é talento, ta? ... É uma coisa que eu acho assim: É a primeira coisa é você conseguir detectar no meio de um monte de gente quem tem talento pra coisa, ta?... É isso que eu falo, são poucas as pessoas que têm esse talento até como técnico de bater o olho e virar e falar assim: olha, isso pode levantar. ... Hoje um grande levantador sabe na hora o que ele tem que fazer. Muitas vezes sem...... não todas as jogadas que você consegue fazer no treino, sempre tem uma ou duas dentro de campo que você não fez e naquela hora (carta na manga) exatamente. ...

S14 - Bom, primeiro é o seguinte, eu acho que o levantador não tem tanto estímulo igual o atacante né...o maior estímulo que tem o voleibol é o ataque, então toda criança quer ser atacante. Raramente você pega criança pra ser levantadora, então depende do...da...dos técnicos que trabalham com essas atletas pra sabe... desenvolver isso ai, não adianta pega baixinho, se levantador, alto se atacante, isso dura três anos, depois a criança baixinha dificilmente ela joga, então acho que os técnicos têm que trabalhar com essa parte ai pra gente pegar um atleta caído do céu acho muito difícil, basta saber que o (...) antigamente era atacante e depois passou a ser levantador, (...) , ela era atacante e depois passou a ser levantadora, então acho que mais a parte do...do técnico cativar o atleta do que o atleta ser cativado, isso é um ponto de vista ... então o estímulo mais forte no voleibol é o ataque... $1^{\text {a }}$ Idéia - O principal de um levantador é a parte psicológica.

$2^{a}$ Idéia - Gostar de levantar.

$1^{a}$ Idéia - É preciso ter talento (ser criativo).

O levantador não tem tanto estímulo. 
QUADRO 8 - $\underline{\text { Categoria D - Expressões Chave e Idéias Centrais dos Aspectos Psicológicos (cont.) }}$

S15 - Acho que nossa posição...é uma posição assim muito ...é...ela exige muita assim...muita concentração acho que levantador tem que ser muito concentrado, observador e acho que...isso faz a diferença, a gente não pode ser um atleta assim que vibre demais, que pule demais por que a gente tem que estar concentrado o tempo inteiro, então essa vibração às vezes tira um pouco da concentração...mas acho que observar muito, ser muito observador acho que isso é importante pra você chegar num alto nível .

S13 - Acho que o ponto principal hoje é uma análise que o levantador tem que fazer, não só de aspectos técnicos, táticos, mas, principalmente psicológicos. É importante que o atleta hoje, que o levantador conheça o atleta, inclusive que passe o que ele sente, né? Pra que em momentos decisivos do jogo ele possa saber quem é que ta mais preparado pra poder receber uma bola... E o levantador tem que ser uma pessoa especial, uma pessoa que realmente tenha a sensibilidade, tenha a sobriedade, né? ...

S17 - ...o Brasil hoje tá escasso mesmo de levantadores e levantadoras,é....masculino e feminino,é uma realidade que é um futuro ameaçado mesmo, por que um levantador não é feito da noite pro dia,eu acho que tem que ter... é determinação, é liderança, é habilidade, é a visão de jogo,é...enfim é conhecer o jogo de voleibol por um todo, é e...psicologicamente você tem que ta sempre bem,por que nos momentos decisivos todos...sempre todas as bolas passam na sua mão, e nos momentos decisivos você tem que ta lúcido, pra saber qual a melhor jogada que você vai fazer,eu acho que é isso,é....é bem por ai mesmo.

S21 - ...primeiro eu acho que ele tem que ser muito bom tecnicamente e segundo eu acho que ele tem que ter muita percepção. Eu acho que tem determinados momentos do jogo que ele tem que perceber quem é que ta melhor, quem é que tem que receber aquela bola, independente de qual bola seja. Eu acho que isso é o mais importante pro levantador... pq tem momento no jogo, por ex. 23 a 23 que ele tem que perceber quem é que ta melhor psicologicamente e com coragem pra decidir aquela bola. Ele não pode né? No 23 a 23 dar uma bola pra aquela pessoa que errou as três bolas anteriores ou que ele sentiu que não ta bem. Então...é um momento de decisão então eu acho que ele tem que perceber quem é que ta melhor naquele momento pra poder ganhar o jogo na verdade.
Levantador tem que ser muito concentrado.

$1^{\text {a }}$ Idéia - O levantador tem que conhecer o atleta com quem joga. ga. D

O levantador não é feito da noite pro dia e tem que estar bem psicologicamente.

O levantador tem que ter muita percepção.

D

continua 
QUADRO 8 - $\underline{\text { Categoria D - Expressões Chave e Idéias Centrais dos Aspectos Psicológicos (cont.) }}$ S16 - Acho que o primeiro é a liderança né...saber comandar um
time, que toda bola passa na sua mão e tem que ter essa
tranqüilidade né, de liderar o time....

S4 - ... a liderança, ...na psicológica, tem que ser uma pessoa muito inteligente que tenha uma visão é...ampla, né?..é...ter uma percepção muito boa pra que ele posso distribuir é...as bolas devidas pra seus atacantes.

S18 - ... dificilmente você consegue treinar ou consegue embutir na cabeça do jogador jovem é a necessidade dele utilizar as armas que ele tem na mão é... por exemplo, em questão de relacionamento ele tem que ser um líder, ele tem que ter conhecimento dos atacantes dele né... isso já tá embutido na liderança, de o cara ser um líder ele sabe como desfrutar melhor dos seus companheiros, não no sentido pejorativo é... que ele sabe como se comunicar com um e outro, ele sabe se ele der uma bronca em um jogador ele não vai render e pra ele vai ser ruim, né... ele sabe quem que ele pode por um pouco mais de velocidade que ...que ele não pode por, então ele é respeitado por outros jogadores, ele tem um equilíbrio emocional muito grande por que ele nunca pode perder a cabeça né... a partir do momento que o levantador fica nervoso e para de raciocinar na plenitude, ele deixa de utilizar uma serie de informações durante o jogo que isso é imprescindível para um desempenho dentro do jogo né... para de analisar o time adversário, para de analisar o próprio time né... essa sensibilidade até de saber se um companheiro dele ta bem ou não na partida independente do técnico tirar ou não né... é ele tem que transmitir confiança né... e nisso ta muito ligado com a parte técnica, treino, trabalho, então é uma coisa global e... e muita arestas pra você realmente ter o jogador de alto nível , que contenha tudo isso né... o (...), por exemplo, atualmente ele tem já um nível de inteligência assim... pro voleibol a ponto de...ele pode odiar um cara que ta jogando com ele né... mas se ele souber que o cara ta bem naquela hora e vai ajudar ele a ganhar ele vai por a bola pra aquele cara né... mas esse discernimento passa só a vir muito com a experiência a gente falando da criação dos novos levantadores é uma coisa que tem que ser meio nata né... ele tem que ter essa sensibilidade isso é difícil de ser treinado isso é muito difícil essa liderança não ostensiva né, mas conquistada sem ter que fazer força é uma coisa que poucos garotos tem , ... $1^{a}$ Idéia - O primeiro quesito do levantador é a liderança.

$2^{\mathrm{a}}$ Idéia - Exigência psicológica do levantador.

$2^{\mathrm{a}}$ Idéia - A liderança do levantador. 
QUADRO 8 - Categoria D - Expressões Chave e Idéias Centrais dos Aspectos Psicológicos (cont.)

\begin{tabular}{|c|c|}
\hline $\begin{array}{l}\text { S23 - ... O levantador realmente tem que estar com a cabeça } \\
\text { ligado, pensando durante o tempo todo do jogo, entender o que } \\
\text { está sendo feito, o que tem que ser feito, a estratégia que tem } \\
\text { que ser feita, ah. Pra jogar contra o adversário, então o lado } \\
\text { psicológico do levantador é muito mais importante do que o lado } \\
\text { físico. }\end{array}$ & $\begin{array}{l}\text { O psicológico do } \\
\text { levantador é mais } \\
\text { importante do que o } \\
\text { físico. }\end{array}$ \\
\hline $\begin{array}{l}\text { S20 - ...primeiro requisito num levantador tem que ser inteligente, } \\
\text { inteligente eu digo, tem que ser uma pessoa tranqüila, tem uma } \\
\text {...tem que ser uma pessoa ou um atleta de raciocínio rápido e } \\
\text { que assimile a ... o jogo em si, eu não simplesmente jogue a bola } \\
\text { mecanicamente que é o que a gente vê, eu não vou dizer nomes, } \\
\text { mais eu acho a (...) uma craque de bola, que sabe raciocinar } \\
\text { durante o jogo e outras levantadoras no Pais, feminino que são } \\
\text { bem treinadas, elas são bem treinadas, elas não sabem o que } \\
\text { elas estão fazendo, me desculpe, mais essa é a minha opinião. }\end{array}$ & $\begin{array}{l}\text { O primeiro requisito do } \\
\text { levantador é a } \\
\text { inteligência. }\end{array}$ \\
\hline $\begin{array}{l}\text { S19 - ... a levantadora é a alma do time né? pq todas as bolas } \\
\text { passam pela mão da levantadora, então ela é que sabe o que vai } \\
\text { fazer... a jogada que vai fazer, então eu acho que se ela não tiver } \\
\text { é...é... um raciocínio um pouco mais rápido e melhor do que uma } \\
\text { atacante...é ....bom eu acho que ela não tem condições de jogar } \\
\text { lá fora ou mesmo de jogar grandes partidas aqui dentro do } \\
\text { Brasil.... a principal característica de um levantador é a } \\
\text { inteligência, eu acho que um levantador que não é inteligente não } \\
\text { consegue jogar jamais....não tem condições de jogar. Eu acho } \\
\text { assim...que a gente fala muito de (...), a (...) além dela ser muito } \\
\text { habilidosa, ela é extremamente inteligente, então..ela joga com } \\
\text { aquela pessoa que tá rodando. Vamos supor, eu já joguei com } \\
\text { ela na seleção e calhou de um jogo eu estar muito bem. Eu } \\
\text { recebi } 50 \text { bolas e a segunda que recebeu, recebeu três. então ela } \\
\text { joga ... ela usa a inteligência dela em função de quem estiver } \\
\text { bem, quem tiver rodando ...você não vai esperar a (...) fazer } \\
\text { jogadas mirabolantes de tá lá na ponta e ela inverter pra saída ou } \\
\text { de um fundo. Ela sempre joga aquele jogo mais simples, não que } \\
\text { seja simples, mas...é mais cadenciado, mas ela é extremamente } \\
\text { inteligente por causa disso, e eu digo assim...é....a alma do time } \\
\text { pq , a gente ...todas as atacantes precisam esperar pela } \\
\text { levantadora pra fazer uma ação. Então a gente precisa sempre } \\
\text { esperar por ela, e se...ela.. por exemplo, não tiver no jogo, não } \\
\text { tiver bem naquele dia , não tem jogo, acabou o jogo, né? Pq não } \\
\text { tem o que você fazer, não tem o que uma atacante resolver, pq } \\
\text { ela não vai tocar na bola e sempre a bola vai passar pela } \\
\text { levantadora. Eu acho por isso a levantadora é a alma do time. }\end{array}$ & $\begin{array}{l}\text { A levantadora é a alma } \\
\text { do time. }\end{array}$ \\
\hline
\end{tabular}


QUADRO 8 - $\underline{\text { Categoria D - Expressões Chave e Idéias Centrais dos Aspectos Psicológicos (cont.) }}$

\begin{abstract}
S7 - ...agora psicologicamente ela tem que ter muita paciência tem que saber ouvir muito, quando eu digo ouvir é... ouvir e não se influenciar por tudo, porque é nela que vem tudo, é o técnico que fala, as jogadoras falam. Então ela tem que ser rápida, ela tem que ouvir, filtrar o que serviu e o que não serviu, tem que passar. Ela tem que ter uma personalidade forte, porque ela tem que saber se impor. Eu acho que não é pra dizer, que não tem que ouvir, não tem que aceitar a opinião de ninguém, mas ela tem que saber se impor na quadra. Ela tem que mandar na quadra, assim como o técnico comanda fora, ela tem que ter esse comando dentro da quadra. Eu acho que é a característica $\mathrm{n}^{\circ} 1$, falando do lado psicológico. Saber se impor e comandar o time. E uma outra, acho que tem que ser inteligente, porque ela tem que... existe uma jogadora que não ta muito bem no dia. Tem que saber a hora de falar, ela tem que saber aquela que é melhor você deixar quieta. Tem que saber quem precisa de um empurrão, uma pegada, uma coisa mais positiva. Tem jogadora que você não pode falar em um tom mais agressivo porque sente, e outra não. Então tem que ter tudo isso, tem que saber um pouquinho de cada jogadora que ta jogando do seu lado.
\end{abstract}

S22 - ... Eu acho que com 25 anos ele ta madura, ele ta apto, até mais às vezes, você vê hoje em dia o nosso, ... o principal é a concentração né, o nível de concentração, o domínio, você tem que ter uma reação de poucos segundos, você tem que saber pra onde você vai distribuir uma bola, pra quem você vai levantar, o atacante que psicologicamente naquele momento ta bom, você tem que olhar o bloqueio adversário e tudo isso numa fração de segundos que você só passa a , a entender, a fazer isso com uma precisão depois dos 25 anos até mesmo a entender taticamente o que o seu treinador pede a você....

QUADRO 9 - Discurso do Sujeito Coletivo (DSC) da Categoria D (Aspectos Psicológicos)

1. Para você, quais seriam as variáveis que uma levantadora deve ter para ser uma atleta de alto rendimento e chegar a uma seleção nacional?

\title{
DSC DA CATEGORIA - D
}

Bom, primeiro é o seguinte, eu acho que o levantador não tem tanto estímulo igual o atacante né...o maior estímulo que tem o voleibol é o ataque, então 
toda criança quer ser atacante. Raramente você pega criança pra ser levantadora, então depende do...da...dos técnicos que trabalham com essas atletas pra sabe... desenvolver isso ai, não adianta pega baixinho, se levantador, alto se atacante, isso dura três anos, depois a criança baixinha dificilmente ela joga, então acho que os técnicos têm que trabalhar com essa parte ai pra gente pegar um atleta caído do céu acho muito difícil, basta saber que o (...) antigamente era atacante e depois passou a ser levantador, (...), ela era atacante e depois passou a ser levantadora, então acho que mais à parte do...do técnico cativar o atleta do que o atleta ser cativado, isso é um ponto de vista ... ,então o estímulo mais forte no voleibol é o ataque...

O Brasil hoje tá escasso mesmo de levantadores e levantadoras,é...masculino e feminino,é uma realidade que é um futuro ameaçado mesmo, por que um levantador não é feito da noite pro dia,eu acho que tem que ter... é determinação, é liderança, é habilidade, é a visão de jogo,é...enfim é conhecer o jogo de voleibol por um todo, é e...psicologicamente você tem que ta sempre bem,por que nos momentos decisivos todos...sempre todas as bolas passam na sua mão, e nos momentos decisivos você tem que ta lúcido, pra saber qual a melhor jogada que você vai fazer,eu acho que é isso,é....é bem por ai mesmo.

Hoje pra você ter um bom levantador, $1^{\circ}$ é talento, tá? ... É uma coisa que eu acho assim: É a primeira coisa é você conseguir detectar no meio de um monte de gente quem tem talento pra coisa, tá?... É isso que eu falo, são poucas as pessoas que têm esse talento até como técnico de bater o olho e virar e falar assim: olha, isso pode levantar. Hoje um grande levantador sabe na hora o que ele tem que fazer. Muitas vezes não são todas as jogadas que você consegue fazer no treino, sempre tem uma ou duas dentro de campo que você não fez e naquela hora (carta na manga) exatamente.

Eu acho que com 25 anos ele ta madura, ele ta apto, até mais às vezes, você vê hoje em dia o nosso, ... o principal é a concentração né, o nível de concentração, o domínio, você tem que ter uma reação de poucos segundos, você tem que saber pra onde você vai distribuir uma bola, pra quem você vai levantar, o atacante que psicologicamente naquele momento ta bom, você tem que olhar o bloqueio adversário e tudo isso numa fração de segundos que você só passa a , a 
entender, a fazer isso com uma precisão depois dos 25 anos até mesmo a entender taticamente o que o seu treinador pede a você.

Olha... eu acho que o principal de um levantador ta na parte psicológica...por que às vezes...muitas vezes quando tem deficiência física e deficiência técnica, ele consegue fazer o jogo pelo controle emocional dele e pelo controle que ele tem sobre a avaliação que ele faz dos companheiros de jogo dele...eu vou falar mais em termo de feminino por que é onde eu mais trabalho...então eu entendo que as variáveis psicológicas do controle emocional a observação e a facilidade de analise do colega...qual momento eu posso usar esse jogador, qual o momento eu não posso usar esse jogador, a identificação de como o jogador reage com determinado tipo de bola ...qual é a maior eficiência dele qual a maior deficiência dele, como se dirigir com o jogador que ela vai levantar a bola, se ela deve ser agressiva , se ela deve ser carinhosa, se ela deve ser atenciosa...então eu acho que esse é um componente fundamental pra uma levantadora de altíssimo nível....

Acho que o ponto principal hoje é uma análise que o levantador tem que fazer, não só de aspectos técnicos, táticos, mas, principalmente psicológicos. É importante que o atleta hoje, que o levantador conheça o atleta, inclusive que passe o que ele sente, né? Pra que em momentos decisivos do jogo ele possa saber quem é que ta mais preparado pra poder receber uma bola... E o levantador tem que ser uma pessoa especial, uma pessoa que realmente tenha a sensibilidade, tenha a sobriedade, né? ...

Acho que essa posição...é uma posição assim muito ...é...ela exige muita assim...muita concentração, acho que levantador tem que ser muito concentrado, observador e acho que...isso faz a diferença, não pode ser um atleta assim que vibre demais, que pule demais por que tem que estar concentrado o tempo inteiro, então essa vibração às vezes tira um pouco da concentração...mas acho que observar muito, ser muito observador acho que isso é importante pra você chegar num alto nível.

Eu costumo falar sobre levantadora, gosto muito do aspecto emocional da levantadora né? Acho que a levantadora tem que ser uma líder, ela tem que ter uma liderança positiva em relação às atacantes... então eu gosto muito de puxar nas 
minhas levantadoras, isso aqui, essa liderança e esse desafio,... Então a levantadora tem que ser forte, ela tem que ter perseverança, tem que ser dedicada, tem que ser a primeira a chegar no treino, a última a sair, tem que estar entrosada com o técnico, em todo o esquema tático, tanto na sua equipe quanto das outras equipes. Quais são os pontos mais fortes da sua equipe, e juntos traçar isso no começo da temporada, junto com o seu técnico e a cada jogo estudar e ver o que é que a gente pode fazer em relação à equipe adversária, mas principalmente ter uma liderança em cima das atacantes, pra que as atacantes não fujam das responsabilidades, colocando sempre a culpa nas levantadoras.

Eu acredito também no equilíbrio né? Equilíbrio emocional, é.... conhecimento de jogo, né? ... Então, a (...) é uma menina que foi uma jogadora que sempre teve muita liderança, que eu acho fundamental, conhecimento de jogo, é ..... equilíbrio, lógico. Equilíbrio quando eu falo é..... se mantém muito equilibrada. Todas elas já convivi, com essas jogadoras todas aí, de perto. Todas elas têm seu momento de desequilíbrio, mas a (...) se mantém por mais tempo em equilíbrio, precisão, né? Técnica.

O primeiro é a liderança né?...saber comandar um time, que toda bola passa na sua mão e tem que ter essa tranqüilidade né? de liderar o time. Dificilmente você consegue treinar ou consegue embutir na cabeça do jogador jovem a necessidade dele utilizar as armas que ele tem na mão é... por exemplo em questão de relacionamento ele tem que ser um líder, ele tem que ter conhecimento dos atacantes dele né... isso já tá embutido na liderança, de o cara ser um líder, ele sabe como desfrutar melhor dos seus companheiros, não no sentido pejorativo é... que ele sabe como se comunicar com um e outro, ele sabe se ele der uma bronca em um jogador ele não vai render e pra ele vai ser ruim, né... ele sabe quem que ele pode por um pouco mais de velocidade que ...que ele não pode por, então ele é respeitado por outros jogadores, ele tem um equilíbrio emocional muito grande por que ele nunca pode perder a cabeça né... a partir do momento que o levantador fica nervoso e para de raciocinar na plenitude, ele deixa de utilizar uma serie de informações durante o jogo que isso é imprescindível para um desempenho dentro do jogo né... pára de analisar o time adversário, pára de analisar o próprio time né... essa sensibilidade até de saber se um companheiro dele ta bem ou não na partida 
independente do técnico tirar ou não né... é ele tem que transmitir confiança né... e nisso ta muito ligado com a parte técnica, treino, trabalho, então é uma coisa global e... e muita arestas pra você realmente ter o jogador de alto nível, que contenha tudo isso né... o (...) por exemplo, atualmente ele tem já um nível de inteligência assim... pro voleibol a ponto de...ele pode odiar um cara que ta jogando com ele né... mas se ele souber que o cara ta bem naquela hora e vai ajudar ele a ganhar ele vai por a bola pra aquele cara né... mas esse discernimento passa só a vir muito com a experiência a gente falando da criação dos novos levantadores é uma coisa que tem que ser meio nata né... ele tem que ter essa sensibilidade isso é difícil de ser treinado isso é muito difícil essa liderança não ostensiva né mas conquistada sem ter que fazer força é uma coisa que poucos garotos tem. Então a levantadora é a alma do time né? pq todas as bolas passam pela mão da levantadora, então ela é que sabe o que vai fazer... a jogada que vai fazer, então eu acho que se ela não tiver é..é... um raciocínio um pouco mais rápido e melhor do que uma atacante...é ...bom eu acho que ela não tem condições de jogar lá fora ou mesmo de jogar grandes partidas aqui dentro do Brasil.

Outra característica de um levantador é a inteligência, eu acho que um levantador que não é inteligente não consegue jogar jamais...não tem condições de jogar. Eu acho assim...que a gente fala muito de (...), a (...) além dela ser muito habilidosa, ela é extremamente inteligente, então..ela joga com aquela pessoa que tá rodando. Vamos supor, eu já joguei com ela na seleção e calhou de um jogo eu estar muito bem. Eu recebi 50 bolas e a segunda que recebeu, recebeu três. então ela joga ... ela usa a inteligência dela em função de quem estiver bem, quem tiver rodando ...você não vai esperar a (...) fazer jogadas mirabolantes de tá lá na ponta e ela inverter pra saída ou de um fundo. Ela sempre joga aquele jogo mais simples, não que seja simples mas...é mais cadenciado, mas ela é extremamente inteligente por causa disso, e eu digo assim...é...a alma do time pq, a gente ...todas as atacantes precisam esperar pela levantadora pra fazer uma ação. Então a gente precisa sempre esperar por ela, e se...ela.. por exemplo não tiver no jogo , não tiver bem naquele dia, não tem jogo, acabou o jogo, né? Pq não tem o que você fazer, não tem o que uma atacante resolver, pq ela não vai tocar na bola e sempre a bola vai passar pela levantadora. Eu acho por isso a levantadora é a alma do time. 
Agora.... ela tem que ter muita paciência, tem que saber ouvir muito, quando eu digo ouvir é... ouvir e não se influenciar por tudo, porque é nela que vem tudo, é o técnico que fala, as jogadoras falam. Então ela tem que ser rápida, ela tem que ouvir, filtrar o que serviu e o que não serviu, tem que passar. Ela tem que ter uma personalidade forte, porque ela tem que saber se impor. Eu acho que não é pra dizer, que não tem que ouvir, não tem que aceitar a opinião de ninguém, mas ela tem que saber se impor na quadra. Ela tem que mandar na quadra, assim como o técnico comanda fora, ela tem que ter esse comando dentro da quadra. Eu acho que é a característica $n^{\circ} 1$, falando do lado psicológico. Saber se impor e comandar o time. E uma outra, acho que tem que ser inteligente, porque ela tem que... existe uma jogadora que não ta muito bem no dia. Tem que saber a hora de falar, ela tem que saber aquela que é melhor você deixar quieta. Tem que saber quem precisa de um empurrão, uma pegada, uma coisa mais positiva. Tem jogadora que você não pode falar em um tom mais agressivo porque sente, e outra não. Então tem que ter tudo isso, tem que saber um pouquinho de cada jogadora que ta jogando do seu lado.

Após o procedimento da categorização das Idéias Centrais, as respostas de sentido equivalente foram agrupadas em um conjunto ao qual se lançou um nome que expressasse esse sentido (Aspectos Físicos, Aspectos Técnicos, Aspectos Táticos e Aspectos Psicológicos), e calculada a sua Força - freqüência com que uma dada Idéia Central apareceu no campo pesquisado, ou seja, no total das respostas proferidas pelos entrevistados.

Os resultados obtidos permitiram identificar a existência de predominâncias, nas características de comportamento, dos aspectos psicológicos necessários aos levantadores de alto rendimento, de acordo com a opinião dos sujeitos (FIGURAS 1 e 2). 


\section{FORÇA DAS IDÉIAS CENTRAIS}

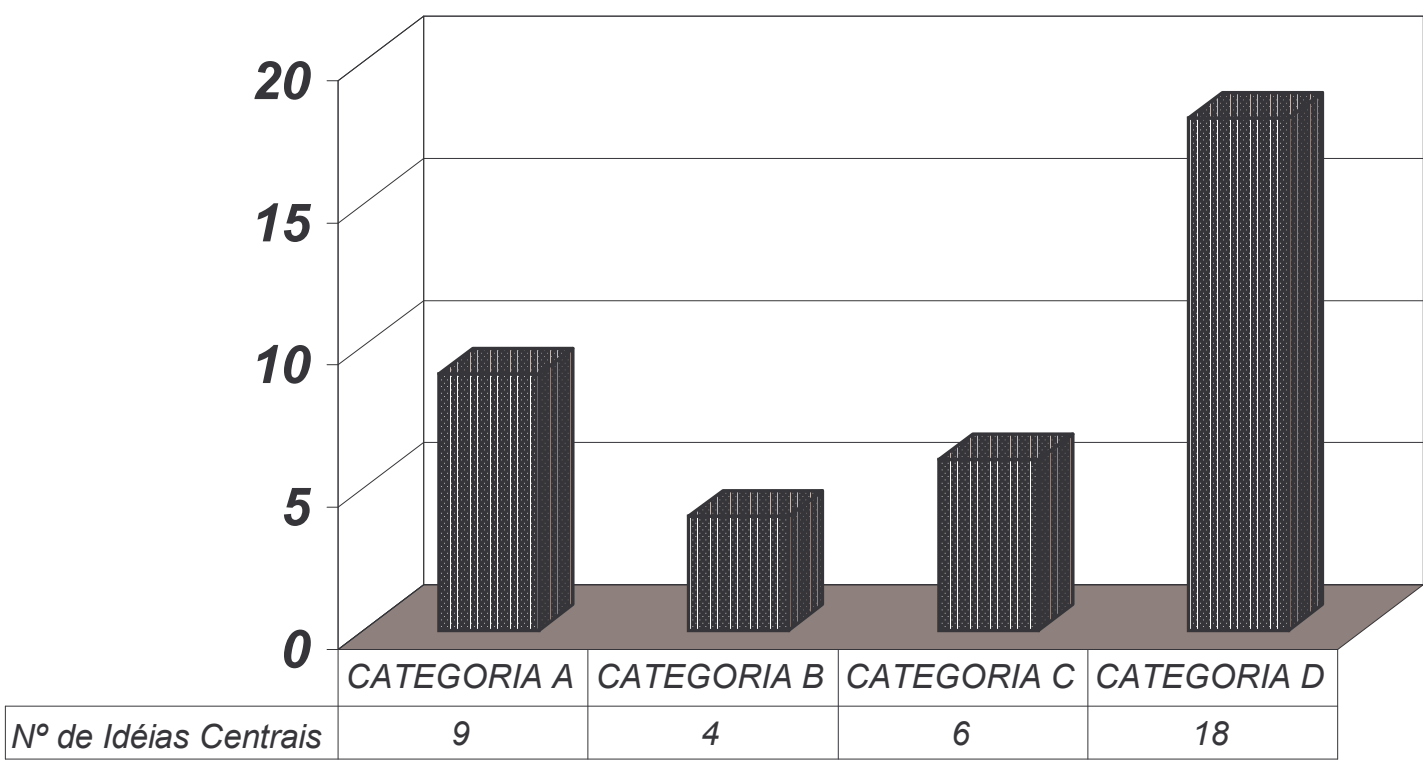

FIGURA 1 - Forca das Idéias Centrais no total dos discursos proferidos pelos entrevistados em valores absolutos. 


\section{\% DA FORÇA DAS IDÉIAS CENTRAIS}

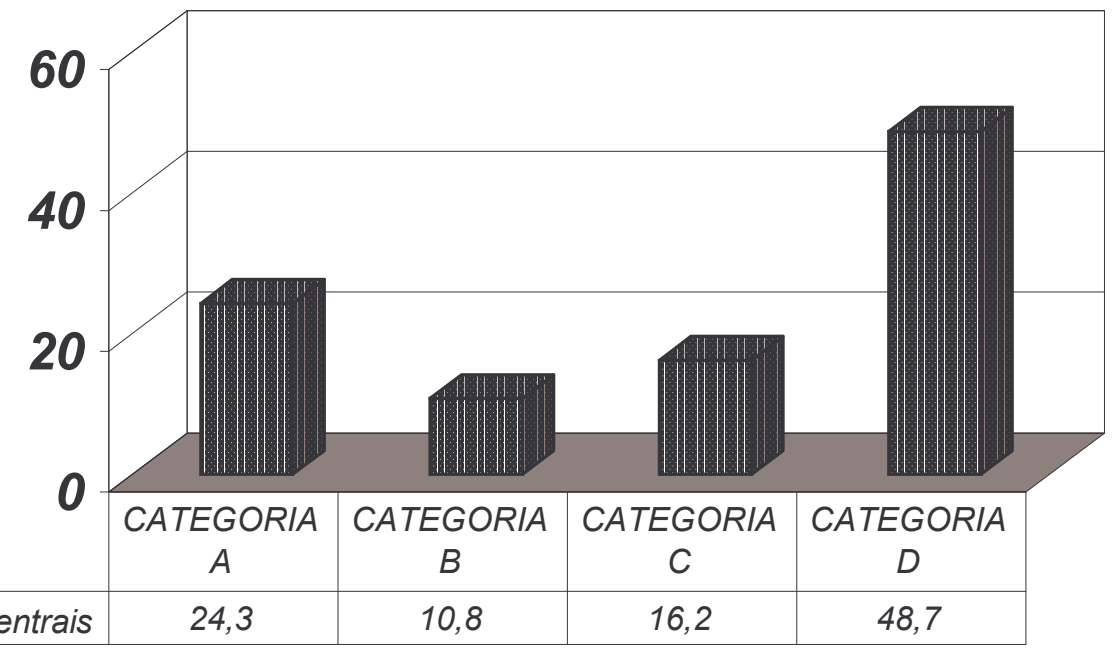

FIGURA 2 - Força das Idéias Centrais no total dos discursos proferidos pelos entrevistados em valores percentuais.

Com base nos resultados obtidos nesta pesquisa, concluiu-se:

- $\quad$ O comportamento tático individual das atletas que atuam na posição de levantadora assumem um papel representativo na eficiência de suas ações individuais e na eficácia coletiva de suas equipes.

- As características de comportamentos das atletas que atuam na posição de levantadora estariam fundamentalmente associadas com os aspectos psicológicos quando comparados com os aspectos físicos, técnicos e táticos;

- O método denominado Discurso do Sujeito Coletivo - "DSC" - se tornou um instrumento viável para o desenvolvimento de pesquisas qualitativas no ambiente de equipes esportivas 
Com base nas evidências expostas no presente estudo, recomenda-se:

- Estudos similares com técnicos e atletas de outros esportes sejam realizados, permitindo posteriores comparações sobre os aspectos que norteiam o comportamento de atletas no esporte de competição e desempenho.

- Que na utilização do "DSC" em outros estudos, sejam observadas outras dimensões de comportamento envolvidos com capacidade de produzir resultados positivos no esporte de competição.

- Que os dirigentes, técnicos e atletas de voleibol do Brasil façam uma reflexão sobre os resultados desse estudo e procure dedicar maior atenção aos aspectos psicológicos envolvidos com comportamento dos técnicos e dos atletas em busca de resultados positivos dentro dos diferentes eventos nacionais e internacionais. 


\section{REFERÊNCIAS}

BARROS, J. Levantamento - parte 1. Disponível em: <http:/www.esportese.com.br/vôlei/>. Acesso em: 07 jul. 2001.

BIZZOCCHI, C. O voleibol de alto nível: da iniciação à competição. São Paulo: Fazendo Arte Editorial, 2000.

BRUNORO, J. C. Voleibol: a palavra é sua. Revista Brasileira de Ciência e Movimento, São Caetano do Sul, v.1, n.1, p.49-52. 1987.

CALDEIRA, S; MATSUDO, V. K. R. Estudo comparativo dos parâmetros de aptidão física em voleibolistas de alto-nível. In: SIMPÓSIO DE CIÊNCIAS DO ESPORTE, 14.,1986, São Caetano do Sul. Anais... São Caetano do Sul: CELAFISCS, 1986. p.27.

CARDONA, C. D. El levantador de alta competência. Disponível em: <http://www.asocvoleyrosario.com.ar/expertos/expertos.html>. Acesso em: 07 jul. 2001.

CONFEDERAÇÃO BRASILEIRA DE VOLLEYBALL. Balanço de um esporte campeão. Rio de Janeiro, 2001. Disponível em: <http://www.voleibrasil.com.br>. Acesso em: 21 mar. 2001.

- Bernardinho está de olho nos levantadores. Assessoria de imprensa. Disponível em: <http://www.voleibrasil.com.br>. Acesso em: 28 abr. 2002.

CORDEIRO FILHO, C. Levantador: Curso Nacional de Treinadores da CBV, 7-17 de jul. de 2002. 4f. (Notas de aula) 
FEDERAÇÃO INTERNACIONAL DE VOLLEYBALL. Programa Oficial do Campeonato Mundial de Voleibol Feminino. São Paulo: FIVB, 1994.

FEDERAÇÃO PAULISTA DE VOLLEYBALL. Garimpando talentos. Assessoria de imprensa. Disponível em: <http://www.fpv.com.br> Acesso em: 05 mar. 2001.

FOLHA ESPORTE. Veja a evolução do vôlei na quadra. Folha de São Paulo, São Paulo, 18 mai. 1997. Folha esporte. p.4.

GUTENBERG, A. A história da bola. Revista Bolas: Todas as caras do esporte, São Paulo, n.5, p.62-67, 2000.

HIPPOLYTE, R. Setting: the art of conducting a volleyball-team. The Coach, n.4, p.613, 1998.

LAJOLO, M. Marcelle encerra dinastia e será "cérebro" no Mundial. Folha de São Paulo, São Paulo, 29 ago. 2002. Folha Esporte.

LANCELLOTTI, S. Faustball, a primeira sacada: túnel do tempo. Revista Volleyball, São Paulo, n.1, p.16-17, 1994.

LEFÈVRE, F; LEFÈVRE, A. M. C. O discurso do sujeito coletivo - Breve Apresentação da proposta. Disponível em:. <http:/www.fsp.usp.br/ flefevre/resumo.html>. Acesso em: 17 set. 2001. p.

. Os novos instrumentos no contexto da pesquisa qualitativa. In: LEFRÈVRE, F; LEFRÈVRE, A. M. C; TEIXEIRA, J. J. V. O discurso do sujeito coletivo: uma abordagem metodológica em pesquisa qualitativa. Caxias do Sul: Educs, 2000. v.1, p.11-17. 
MacGOWN, C.; FRONSKE, H.; MOSER, L. Setting guidelines and drills. In: MacGOWN, C.; FRONSKE, H.; MOSER, L. Coaching volleyball. building a winning team. Boston: Pearson Education Company , 2001. v.1, p.102-118.

MARCHI JUNIOR, W. "Sacando" o voleibol: do amadorismo à espetacularização da modalidade no Brasil (1970-2000). 2001.267f. Tese (Doutorado em Educação Física) - Faculdade de Educação Física - Universidade Estadual de Campinas, Campinas.

MATSUDO, V. K. R.; PEREIRA, M. H. N.; RIVET, R. E. Migração dos índices Z em atletas da seleção brasileira de voleibol masculino com evolução do nível técnico. In: SIMPÓSIO DE CIÊNCIAS DO ESPORTE, 14.,1986, São Caetano do Sul. Anais... São Caetano do Sul: CELAFISCS, 1986. p.69.

MEIER, M. Practical youth training: training of the female setters. International VolleyTech, v.2, p.26-31, 1995.

MESQUITA, I; GRAÇA, A. O conhecimento estratégico de um distribuidor de alto nível. Treino Desportivo, Porto, n.17, p.15-19, mar. 2002.

MOUTINHO, C.A.; BARRADAS, A ; RAMOS, C. A importância do jogador distribuidor e indicadores para a sua seleção: a opinião dos treinadores de escalões de formação da Associação de Voleibol do Porto. In: CONGRESSO DE EDUCACIÓN FÍSICA E CIÊNCIAS DO DEPORTE DOS PAÍSES DE LÍNGUA PORTUGUESA, 6., 1988, Portugal, 1998. Anais... Porto: 1998, p.55.

NOCE, F. Análise do estresse psíquico em atletas de voleibol de alto-nível: um estudo comparativo entre gêneros. 1999. 152f. Dissertação (Mestrado em Educação Física) - Escola de Educação Física, Universidade Federal de Minas Gerais, Belo Horizonte. 
RESENDE, B. Levantador: uma simples questão de personalidade. Vôlei Técnico, Rio de Janeiro, v.1, n.1, p.5-11, 1995.

ROCHE, F. P. Planejamento estratégico nas organizações desportivas. In: CONFERÊNCIA INTERNACIONAL. 1., 2002, São Paulo. Anais... São Paulo: SESC, 2002. p.2-18.

RUSSO, P. A evolução do voleibol até os anos 40. Revista Volleyball, São Paulo, n.10, p.20-22, 1995.

SAMULSKI, D. Equilíbrio psicológico pode definir uma equipe vencedora. Vôlei Técnico, Rio de Janeiro, n.7, p.19-27, 1996.

SANTOS, C. Futuro ameaçado. Folha de São Paulo, São Paulo, 5 mar. 2001. Caderno de Esportes, p.D6.

SILVA, R. C.; RIVET, R. E. Comparação dos valores de aptidão física geral da seleção brasileira de voleibol masculina/86 por posição de jogo através da estratégia Z CELAFISCS. In: SIMPÓSIO DE CIÊNCIA DO ESPORTE, 15., São Caetano do Sul, 1987. Anais... São Caetano do Sul: CELAFISCS, 1987. p.69.

SILVA, W. C. Levantamento. Revista Saque: a revista do vôlei, São Paulo, n.4, p.57$72,1985$.

THOMAS, J.; NELSON, J. Metodologia de pesquisa na atividade física. 3.ed. Porto Alegre: Artmed, 2002.

VARGAS, R. Especializações. In: VARGAS, R. La táctica del voleibol en competición. Madrid: [s.n.],1980. v.1, p.23-27. 
ZANATTA, W. A. O levantador no voleibol catarinense: processo de seleção e treinamento na categoria infanto-juvenil masculino. 2000. 59f. Monografia (Graduação em Educação Física) - Faculdade de Educação Física, Universidade Federal de Santa Catarina, Florianópolis. 
APÊNDICE I - S1 - Entrevista com um Técnico de Equipe Adulta - Masculino

1. Quais seriam as variáveis que um levantador deve ter para ser um atleta de alto rendimento e chegar a uma seleção nacional?

é...é...eu acho que ficou mais detalhado em cima do questionário que eu respondi, mais só pra gente, fazer algumas considerações esse respeito. É o voleibol hoje de alto nível jogado, ele não necessita tanto aquela agilidade que a gente via, por exemplo, num (...), num (...) que levantavam de qualquer jeito, iam buscar...hoje não tem mais isso, por que a qualidade do jogo, da recepção a qualidade da defesa cresceu muito, então nos temos o jogadores, os levantadores hoje jogando muitas vezes com $80 \%$ das bolas na mão né...eles não precisam mais sair correndo, fazer malabarismo, como a ...algum tempo atrás isso era é...condição é....indispensável à um levantador, então por exemplo (...) o levantador da Holanda tem mais de dois metros de altura e não tem agilidade não é um....em agilidade ele perde de qualquer levantador nosso da primeira divisão né...é....agora é um jogador de nível internacional por que?..por que hoje o voleibol é jogado de forma diferente, isso não é mais uma condição básica, então é preciso hoje é....muito mais é...qualidade é...motoras né, de percepção, de antecipação, de conhecimento do ritmo do jogo, do passe, é de visualização, de raciocínio tático, eu acho que é muito mais isso do que é....agilidade, do que habilidade no toque é...os levantadores Norte Americanos com exceção do (...), é.....não são jogadores hábeis né...que a gente pode comparar ao (...), ao um (...), ao um (...) que são nossos melhore levantadores, mais é...dentro das características do voleibol atual eles se enquadram perfeitamente, por que tem um bom bloqueio, tem uma distribuição de jogo boa, né...é todas essas capacidades ai, qualidades que eu já citei, então hoje mudou um pouco...mudou um pouco, a gente tem que encarar dessa forma pra produzir levantadores capazes de se encaixar nesse novo...novo jogo. 
APÊNDICE II - S2 - Entrevista com uma Atleta Equipe Adulta - Seleção Brasileira

1. Quais seriam as variáveis que um levantador deve ter para ser um atleta de alto rendimento e chegar a uma seleção nacional?

Eu acho que hoje o voleibol cresceu muito e pelas estaturas das jogadoras eu acho que tem que ser uma levantadora alta, é...e habilidosa que eu acho que é muito difícil mas...os pré requisitos são esses, pq as jogadoras mais baixas tem assim uma habilidade natural, né? Então se juntar....a (...) que tem 1,80m de altura e tem essa habilidade. Vc não vê outra jogadora com a altura dela e com a habilidade que ela tem. E a jogadora mais baixa tem essa habilidade, então a habilidade que a (...) tem com a altura dela seria o ideal, ou a altura dela e até maior. 


\section{APÊNDICE III - S3 - Entrevista com uma Atleta de Equipe Adulta - Seleção Brasileira}

1. Quais seriam as variáveis que um levantador deve ter para ser um atleta de alto rendimento e chegar a uma seleção nacional?

Bom, fisicamente, com certeza ter velocidade, estar magrinha, levantadora é gordinha é muito difícil de chegar nas bolas, eu acho a questão física é muito importante, pra você é...pra você chegar com equilíbrio nas bolas, coisa que as vezes...até eu comentando com o (...) .... levantadora dele até hoje vou observar mais, que ela chega atrasada nas bolas, pra passe estourado ai a bola sai torta, ela tem que entrar mais de frente, então são coisas assim, que eu acho que são detalhes que a gente tem que consertar agora que esta nessa idade do aprendizado inda, a levantadora é muito...constantemente, acho que nunca vai ter uma hora que o levantador chegou na melhor forma, por que tem sempre pra melhorar, o bloqueio cada dia mais perto,hoje o jogo ta muito...muito matemático né...aquela coisa de informática em cima, coisa que eu não gosto, eu gosto daquele voleibol cru, que você tem que fazer da sua cabeça, que não os técnicos tem que te passar, ver vídeo, eu gosto daquela coisa, que você que tem que improvisar, você que tem que chegar ali na quadra e resolver, ver o que você tem que fazer, eu acho que ai você cresce...

Eu não sou a favor dessa tecnologia pro esporte....mais assim a questão do levantador, eu acho que os treinos técnico são de super importância, eu acho que eu cresci, eu atingi meu ápice, quando eu peguei o Bernardo como técnico mesmo,por que os treinos dele, são os melhores que eu já vi no mundo, é...pra levantador a nível de deslocamento, de inversão, de você treinar vendo o bloqueio, enfim, ele te da um treinamento que engloba tudo que um levantador precisa ter... é...todos os sentidos...acho que só vendo um treino dele de levantamento que você vai ver como é que você rala, por que você vai ver que isso da resultado. 


\section{APÊNDICE IV - S4 - Entrevista com um Técnico de Categoria Menor}

1. Quais seriam as variáveis que um levantador deve ter para ser um atleta de alto rendimento e chegar a uma seleção nacional?

A parte física acredito que hoje a alto nível, esta exigindo muito a altura, a liderança, habilidade em manuseio com a bola e a visão tática que ele vai ter do é.... seu jogador, da sua equipe e da equipe adversária.....na psicológica, tem que ser uma pessoa muito inteligente que tenha uma visão é...ampla, né?..é...ter uma percepção muito boa pra que ele posso distribuir é...as bolas devidas pra seus atacantes. 
APÊNDICE V - S5 - Entrevista com um Técnico Equipe Adulta - Feminino

1. Quais seriam as variáveis que um levantador deve ter para ser um atleta de alto rendimento e chegar a uma seleção nacional?

bom.. é...antes disso, apesar dessa reportagem tenha sido de 2001, é..a levar em consideração o seguinte, que ...por exemplo, se a situação não esta muito boa pra levantadores, mais a gente tem que pensar que poderia estar pior, por que?...por que a exatamente 13 anos atrás, foi tomada uma resolução que muita gente desconhece no qual nas regras do voleibol, hoje as categorias ela a 13 anos atrás não tinha limitação tática pro jogo, então desde o pré-mirim ate 0 adulto se poderia jogar de qualquer forma e a partir de 88 começou a ter essas mudanças na regra, na estruturação tática, então, ou seja a ...naquela época em 88, começou com a obrigatoriedade das equipes, ate infantil, jogar no sistema 6,0 isso em função, dois aspectos, em função de diminuir o numero de lesões, em função da alta quantidade de salto, que a jogadora...por exemplo, fazendo meio no pré-mirim, mirim, ate chagar com uma carga de salto tão grande que no jogo do juvenil, já tinha que operar joelho etc...com lesões precoces, e a outra foi exatamente de revelar jogadoras pra essa função de meio, então é....antigamente quando se montava uma equipe não se fazia pela qualidade individual do jogador, qualidade técnica, então ou seja o jogador com acima, o jogador novo ou uma jogadora nova que tinha uma estatura acima da mediana, ela já ia, já era colocada na posição de atacante, e muitas vezes um jogador mais alto, tinha habilidade pra ser levantador, mais ele nunca era recrutado, sempre quem seria recrutado, são jogadores mais baixos, e.. de certa forma, eu vejo assim, teve, quer queira que não, teve um resultado, por que hoje, no dia de hoje, 18-08-2001 a atual...é...levantadora da seleção brasileira que é a Fabiana Berto, ela veio desse tempo, particularmente é uma jogadora que eu trabalhei nessa categoria, ela chegou como atacante, em função da obrigatoriedade de ser. 
APÊNDICE V - S5 - Entrevista com um Técnico Equipe Adulta - Feminino (cont.)

levantadora, passar pelo meio, então ela se destacou, e hoje ela tem uma estatura, não é das melhor...das maiores, mais já dá pro nível internacional encarar, uma competição de nível internacional, e ela veio dessa possibilidade de revelar jogadoras em função da categoria, em função de jogar necessariamente uma posição tática, agora eu...na minha experiência como técnico eu vejo que realmente faltam além de um aspecto ter jogadora e jogadores que tenham uma condição é... privilegiada como no masculino o (...) e o (...) que é característica técnica muito boa e daí com o amadurecimento taticamente ele vai melhorando muito ai isso é uma coisa que nós temos hoje, tanto no feminino, como no masculino que jogadoras que tem uma dedicação e tem uma disciplina tática muito boa, mais o aspecto técnico inicial, de discernimento de jogo e malicia de jogo, realmente diminuiu, então taticamente as jogadoras são mais obediente, elas procuram observar mais o jogo, e tal etc...agora técnica pura, de levantador com uma certa estatura mediana e que se destaque, tenha realmente é...malandragem no bom sentido do jogo, ta faltando mais, em jogadoras...e jogadoras com estatura muito boa, com levantamento cresceu muito, a gente vê isso muito no masculino e no feminino, mais que aquele dote mesmo de fazer, de tentar sempre burlar o adversário, o bloqueio adversário eu acho que tem faltado. 


\section{APÊNDICE VI - S6 - Entrevista com um Técnico Equipe Adulta - Feminino}

1. Quais seriam as variáveis que um levantador deve ter para ser um atleta de alto rendimento e chegar a uma seleção nacional?

Eu... O aspecto físico hoje é muito importante, é ... hoje principalmente no voleibol feminino, com o crescimento do ataque internacional, a altura das jogadoras, hoje uma levantadora, ela tem que aí, uma ... Não precisa nem ser grande, mas ela tem que ter uma envergadura e um alcance alto, é ... alto, num padrão alto. Acho que é a primeira coisa, porque senão você acaba .... por mais que ela seja habilidosa. Por mais que ela tenha todas as características de distribuição do jogo, é ... são três passagens ali que pro alto nível é... você acaba socando muito, mas eu ... eu costumo falar sobre levantadora, gosto muito do aspecto emocional da levantadora né? Acho que a levantadora tem que ser uma líder, ela tem que ter uma liderança positiva em relação às atacantes. Eu fui atacante muito tempo e o atacante aqui, principalmente no Brasil é ...tudo acaba sempre no levantador, então, já virou assim, um pouco de lenda, né? Que o problema ta no levantamento, então essa jogadora é importante e só e ganha campeonato com essa levantadora, com ... então eu gosto muito de puxar nas minhas levantadoras, isso aqui, essa liderança e esse desafio, de quebrar esse rótulo que aqui no Brasil algum tempo é dado ao voleibol feminino, principalmente na categoria adulta. Então a levantadora tem que ser forte, ela tem que ter perseverança, tem que ser dedicada, tem que ser a primeira a chegar no treino, a última a sair, tem que estar entrosada com o técnico, em todo o esquema tático, tanto na sua equipe quanto das outras equipes. Quais são os pontos mais da sua equipe, e juntos traçar isso no começo da temporada, junto com o seu técnico e a cada jogo estudar e ver o que é que a gente pode fazer em relação à equipe adversária, mas principalmente ter uma liderança em cima das atacantes, pra que as atacantes não fujam das responsabilidades, colocando sempre a culpa nas levantadoras. 


\section{APÊNDICE VII - S7 - Entrevista com uma Atleta Equipe Adulta - Seleção Brasileira}

1. Quais seriam as variáveis que um levantador deve ter para ser um atleta de alto rendimento e chegar a uma seleção nacional?

Bom, hoje em dia como característica física eu acho que se encaixa um pouco como atacante. Levantadora antigamente era sempre a baixinha do time, tinha até um biótipo físico diferente das outras jogadoras. Hoje não, levantadora precisa ser tão alta quanto.... eu acho que no mínimo 1,80m pra jogar em nível internacional. Sempre tão forte quanto às outras, porque ela precisa saltar, ela precisa bloquear. Hoje faz muita falta uma levantadora que não bloqueia. Ela precisa ser ágil na quadra, pra defender, pra correr atrás do passe. Acho que fisicamente hoje ela se enquadra muito como a atacante. E...agora psicologicamente ela tem que ter muita paciência, tem que saber ouvir muito, quando eu digo ouvir é... ouvir e não se influenciar por tudo, porque é nela que vem tudo, é o técnico que fala, as

jogadoras falam. Então ela tem que ser rápida, ela tem que ouvir, filtrar o que serviu e o que não serviu, tem que passar. Ela tem que ter uma personalidade forte, porque ela tem que saber se impor. Eu acho que não é pra dizer, que não tem que ouvir, não tem que aceitar a opinião de ninguém, mas ela tem que saber se impor na quadra. Ela tem que mandar na quadra, assim como o técnico comanda fora, ela tem que ter esse comando dentro da quadra. Eu acho que é a característica $n^{\circ} 1$, falando do lado psicológico. Saber se impor e comandar o time. E uma outra, acho que tem que ser inteligente, porque ela tem que... existe uma jogadora que não ta muito bem no dia. Tem que saber a hora de falar, ela tem que saber aquela que é melhor você deixar quieta. Tem que saber quem precisa de um empurrão, uma pegada, uma coisa mais positiva. Tem jogadora que você não pode falar em um tom mais agressivo porque sente, e outra não. Então tem que ter tudo isso, tem que saber um pouquinho de cada jogadora que ta jogando do seu lado. 


\section{APÊNDICE VIII - S8 - Entrevista com um Técnico Equipe Adulta - Feminino}

1. Quais seriam as variáveis que um levantador deve ter para ser um atleta de alto rendimento e chegar a uma seleção nacional?

Bem, eu acredito primeiro é no equilíbrio né? Equilíbrio emocional, é.... conhecimento de jogo, né? Hoje em dia eu to.... eu falei muito de masculino, mas hoje em dia eu trabalho com feminino. Sempre trabalhei com o feminino. Então eu tenho, é, talvez hoje, eu tive a oportunidade de trabalhar durante 3 anos, 4 anos, sei lê, com a Fernanda, que é ..... que eu acredito que seja a referência pra todas as .... todos os técnicos, todas as gerações. Então, a (...) é uma menina que foi uma jogadora que sempre teve muita liderança, que eu acho fundamental, conhecimento de jogo, é ..... equilíbrio, lógico. Equilíbrio quando eu falo é..... se mantém muito equilibrada. Todas elas já convivi, com essas jogadoras todas aí, de perto. Todas elas têm seu momento de desequilíbrio, mas a (...) se mantém por mais tempo em equilíbrio, precisão, né? Técnica. Hoje em dia a gente vê pelo voleibol da forma que ta, a gente vê muitas jogadoras sendo formadas pra ser levantadora, né? E a gente, eu acredito que o voleibol brasileiro, ele ..... o estilo de jogo, ele não ... ele tem dificuldade de comportar este tipo de jogadora, formada, aquela que entrou na escolinha pra fazer uma atividade e aprendeu a jogar e se tornou, em acho, que o voleibol brasileiro, pela versatilidade que o jogo.... pela dinâmica do jogo, eu acho que ele necessita de grande ... de jogadoras altas, especialmente que tenha o domínio da quadra, do controle do jogo, mesmo, em si, porque para o levantador, principalmente, feminino, ela é fundamental, ela dó o ritmo, ela dá o padrão do jogo e os últimos 10 anos aí a gente vê que o time que tinha a (...) ou a (...) é que eram campeãs da Superliga, com exceção da (...) que eu acho que é, depois das duas, a terceira grande levantadora do Brasil, assim, uma jogadora habilidosa, né? E grande, então, ela está adequada a esses padrões, né? Então eu penso nisso, a jogadora tem que 


\section{APÊNDICE VIII - S8 - Entrevista com um Técnico Equipe Adulta - Feminino (cont.)}

ter conhecimento, realmente, do que se passa dentro da quadra, acho que é o principal, e precisão, né? Técnica, pra que ela possa ditar o ritmo do jogo. 


\section{APÊNDICE IX - S9 - Entrevista com um Técnico de Categoria Menor}

1. Quais seriam as variáveis que um levantador deve ter para ser um atleta de alto rendimento e chegar a uma seleção nacional?

Primeiro lugar o individuo tem que se identificar, tem que gostar da função, segundo tem que ter agilidade, é... a mão boa, como a gente diz na gíria, né e percepção do jogo como um todo...tanto do que ta na sua quadra, do seu lado de quadra, como o do outro lado né e ai acho que está a maior dificuldade que a gente não tem pelo menos no nível em que eu trabalho. A gente tem visto expoentes com essa percepção até pra lidar com o seu próprio grupo, então fica muito amarrado, não desenvolve o jogo, é... as atacantes acabam se irritando por que hora falta habilidade pra bola chegar redondinha, hora falta realmente um pouquinho á mais né... pra diferenciar, é...uma atleta de uma equipe de...da levantadora de uma outra equipe. 


\section{APÊNDICE X - S10 - Entrevista com um Técnico Equipe Adulta - Feminino}

1. Quais seriam as variáveis que um levantador deve ter para ser um atleta de alto rendimento e chegar a uma seleção nacional?

é, bom...é...complicado você falar de levantador por que ele é um...ele é uma solução e é um problema né, solução por que uma equipe de nível técnico médio com um excelente levantador se torna uma equipe boa e uma equipe muito boa com um levantador médio, ela se torna uma equipe media né, você acaba perdendo a condição da sua equipe que seja....o que eu quero colocar é que o levantador ele é o fator determinante, por que ele é o técnico da equipe, ele executa toda a jogadas ofensivas e isso quer dizer que toda vez que a bola for pro lado de lá da rede, num rali, se não houver erro, o levantador estará participando dessa jogada, é o único jogador que participara de todas as jogadas se não haja erro, então você acaba é...tendo que pra entender um levantador, você tenha que entender o que é um técnico, você tem que entender o que é um vencedor, é complicado você colocar algumas situações, eu vejo que algumas coisas acontecem, eu to com vinte e sete anos de voleibol, eu vejo que algumas situações, a gente acaba tendo uma situação de reflexão, primeiro no feminino vou conversar do feminino que é...eu sou especialista e feminino não em masculino mais as levantadoras que nos temos hoje são ...vamos colocar as três melhores jogadoras é....de levantadoras nos vamos ter a (...), a (...) e a (...), são jogadoras que...a (...) começou no ultimo ano de infanto, primeiro de juvenil a ser levantadora, a (...) no juvenil e a (...) no infanto-juvenil pro juvenil e sempre alternando na equipe dela que era a Pirelli em momento em que ela atacava, em momento em que ela levantava, então eu acho que as jogadoras que foram especializadas desde de pequenininha como levantadora não são as jogadoras que estão é....dando rendimento entrando na seleção, com exceção da (...) que foi levantadora desde mirim, as outras a gente sempre tem jogadoras que foram atacantes, então eu acho isso já uma situação meio delicada, segunda coisa é que esse....o ranqueamento, ele foi feito pra atender clubes e não a seleção, então você....é complicado você estar falando sobre é...uma atitude que foi feita 


\section{APÊNDICE X - S10 - Entrevista com um Técnico Equipe Adulta - Feminino (cont.)}

pra clube e não pra seleção....fazer essa comparação é complicado, eu acho que quando fizeram isso esqueceram que nos hoje talvez temos até uma gama no feminino e masculino de levantadores que pode ser pequena, mais se a gente perceber que como precisa de um grande levantador em cada equipe, nos temos dez equipes no feminino, nos temos dez levantadoras e no masculino a mesma coisa, então graças ao ranqueamento que não permitiam dois levantadores de excelente nível na mesma equipe, mudando isso eu acho que nos vamos sentir essa mudança, e pra mim será uma mudança negativa pra seleção pro cenário do voleibol nacional daqui uns dois, três anos, quatro anos, não é uma coisa de imediatista, e a outra coisa que eu acredito que a especialização e que o voleibol dessas jogadoras....que essas jogadoras que a gente cita, elas vivenciaram, que é jogar numa posição definida, ou seja atacante ou levantadora, são as grandes jogadoras nunca jogaram esse sistema que a gente vê alguns anos ai, é.....tiveram no voleibol paulista que é o ...as jogadoras polivalentes, elas jogam no pré-mirim, mirim, fazendo quase que...quem passa pelo meio levanta, ataca na ponta...meio complicado essa falta de...de especialização, por que especialização bem feita, segundo os papas da neurologia e da ....., a especialização bem feita ela é uma ferramenta útil ao incentivo do crescimento do jogador, o problema é que a especialização mau feita é que prejudica o jogador, eu acho que também essa obrigatoriedade de serem jogadores polivalentes nos estamos tirando um pouco de raciocínio especifico e ou especialista ao levantador, então nós estamos hoje pegando levantadores que começam nas categorias....nós estamos pegando levantadores que não tão dando grande rendimento no outro nível, nas categorias de base sim, nos pegamos as ultimas seleções brasileiras infanto juvenis e juvenis desde que a (...) e a (...) saíram e a (...) saíram da seleção às levantadoras tem tudo um metro e setenta e dois, um metro e setenta e três, nos temos que trabalhar a (...) que ta com uma jogadora de um metro e oitenta que era atacante até o ano passado e que ta trabalhando como levantadora o primeiro 


\section{APÊNDICE X - S10 - Entrevista com um Técnico Equipe Adulta - Feminino (cont.)}

ano na seleção agora juvenil, que talvez seja a jogadora que possa crescer no futuro, então eu só acho que a gente identificar os valores ah...ta sendo complicado em todos os momentos tanto na seleção nas categorias de base como nos clubes, isso talvez tenha atrapalhado, mais em aspectos afetivos eu acho que o levantador é uma mescla de todos os ....de todos os valores, de todas as características de vários jogadores ao mesmo tempo, entendeu?...eu acho meio difícil a gente colocar um perfil único pro levantador, até por que se você pegar o (...) que talvez tenha sido o maior levantador estratégico que nos tivemos e pegar o (...) tecnicamente o maior levantador que nos tivemos, eles não tem nenhuma características semelhante, ou a (...) e a (...) também não tem nada, uma não tem nada a ver com a outra, então é meio complicado acho que a miscigenação do ...das valências emocionais talvez façam com que o levantador seja o ponto importante e com certeza será um grande levantador. 


\section{APÊNDICE XXI - S11 - Entrevista com uma EX-Atleta Equipe Adulta - Seleção Brasileira}

1. Quais seriam as variáveis que um levantador deve ter para ser um atleta de alto rendimento e chegar a uma seleção nacional?

Olha, eu vou fazer uma pequena observação com relação a essa regrinha de trazer a $2^{a}$ estrangeira como levantadora, eu acho que isso atrasa o Brasil, um monte, muito, muito, muito. Hoje em dia, ser atacante é bem mais fácil. Então, apesar dos tempos terem mudado desde a minha época, hoje você é atacar é como se fala, eu não to depreciando o atacante, mas é uma coisa muito física, é uma coisa ... o cara assim.... Você começa ler o jornal e assim o cara vai a 3,80 m., o cara vai a 3,60, o cara vai.... entendeu? Então veja uma coisa, o levantador é completamente diferente. Hoje pra você ter um bom levantador, $1^{\circ}$ é talento, ta? Que infelizmente é uma coisa que se ...... no talento. É uma coisa que eu acho assim: É a primeira coisa é você conseguir detectar no meio de um monte de gente quem tem talento pra coisa, ta? Segundo é gostar de levantar. Precisa gostar, precisa, não sei se eu posso falar, um tesão imenso de levantar. Terceiro, tem que ser extremamente inteligente. Quando falo em inteligência, bem, eu falo na inteligência da pessoa que mais ou menos $80 \%$ é nata. Porque hoje o que você tem como levantadora, ou você treina a menina repetitivamente 1.000 toques aqui, 1.000 toques atrás, 1.000 toques no fundo, 1.000 toques na frente, mas assim a inteligência dela vai ter momentos no jogo que vai faltar. ........ é onde que entra a tua inteligência, que vc nasce, onde entra o teu talento pra coisa. Então hoje vc tem algumas atletas que treinaram muito pouco, já conseguem levantar alguma coisa. Tem atletas que tão há dois anos no mercado e não saem mais daquilo, entendeu? Então, quem consegue detectar isso, então? É isso que eu falo, são poucas as pessoas que têm esse talento até como técnico de bater o olho e virar e falar assim: olha, isso pode levantar. Então hoje a grande preocupação que eu achei bárbaro e que o (...) fez, porque o 


\section{APÊNDICE XXI - S11 - Entrevista com uma EX-Atleta Equipe Adulta - Seleção Brasileira (cont.)}

(...) é um cara assim que eu acho um dos melhores do mundo mesmo, acabou de provar isso, ele leva um time que não tem altura. Então não vai falar que o (...) é um grande atacante de ponta, ele é um grande atacante, mas não em altura. Vc vai jogar com a Rússia, porque tem gente de 2.... metros. Então o que ta acontecendo hoje, hoje eles tão querendo pegar levantador com 1,90, 1,95, 2,00 metros de altura: menina de 1,80, 1,85 metros independentemente de achar que elas têm valores ou não. Que elas têm talento ou não. Exatamente pela altura e eu acho que onde eles pecam. O (...) tem a postura dele e quis o (...) com 1,85 e deixou o (...) no banco que tem 1,92. O que aconteceu? Porque emocionalmente o (...) com o (...), o (...) jogou. Então esse tipo de coisa é mais difícil de se achar que o levantador. Quem ........... o levantador é um, atacante são 5. Entendeu? Então, quer dizer, a dificuldade que eu acho de vc ver um levantador ta aí, ..... tem que treinar, tem que se desgastar, ultimamente é muito difícil. Uma (...) é máximo, tem talento. Uma (...) não é máximo, a (...) é muito bem treinada, entendeu? É uma excelente levantadora mas vc vê que vc põe ela do lado da (...), tem grandes ......... mesmo na parte emotiva, mesmo na decisão, isso que eu falo. Hoje um grande levantador sabe na hora o que ele tem que fazer. Muitas vezes sem...... não todas as jogadas que vc consegue fazer no treino, sempre tem uma ou duas dentro de campo que você não fez e naquela hora (carta na manga) exatamente. Combinando é isso, eu acho assim, muita altura, muita altura então o cara quanto você tem? Ah! 1,85 m. tem bom toque então vai levantar. Não é só isso. Eu tava discutindo isso com o (...), porque agora é assim né? Senta eu e ele pra ver jogo de São Caetano. Senta eu, ele, (...), a (...) e a gente fica o tempo inteiro falando disso (risos) Não sei nem como é, mas na minha época saia do treino e ficava 1 hora sozinha dando 1.000 toques. Hoje, a pessoa deu 5 horas acabou o treino, pegou a malinha e picou a mula. Foi embora, agora uma levantadora, além de .... (enrolou)... de ser natural, precisa 
APÊNDICE XXI - S11 - Entrevista com uma Ex-Atleta Equipe Adulta - Seleção Brasileira (cont.)

mais ou menos........treinar e é treinar ........ o quanto precisa treinar. É mais ou menos por aí. Credo, quanto .... vai acabar a fita. 


\section{APÊNDICE XII - S12 - Entrevista com um Técnico de Categoria Menor}

1. Quais seriam as variáveis que um levantador deve ter para ser um atleta de alto rendimento e chegar a uma seleção nacional?

Primeiro, ter obediência e tática, sem obediência técnico e tática, o levantador ele se perde no jogo, muitas vezes você, você quer que o levantador tenha criatividade, mas se essa criatividade não for direcionada, não for direcionada pra aquilo que o jogo exige, o jogador pode se perder, capacidade de raciocínio rápido, acho que é importante e também agilidade de deslocamento, são as variáveis que eu acho que contam bastante para um levantador. O resto você vai estar desenvolvendo, aprimorando né, mas a princípio quando eu vejo um levantador eu busco essas características nele. 


\section{APÊNDICE XIII - S13 - Entrevista com um Técnico de Seleção Brasileira - Categoria de base (menores)}

1. Quais seriam as variáveis que um levantador deve ter para ser um atleta de alto rendimento e chegar a uma seleção nacional?

Acho que o ponto principal hoje é uma análise que o levantador tem que fazer, não só de aspectos técnicos, táticos, mas, principalmente psicológicos. É importante que o atleta hoje, que o levantador conheça o atleta, inclusive que passe o que ele sente, né? Pra que em momentos decisivos do jogo ele possa saber quem é que ta mais preparado pra poder receber uma bola. E o levantador tem que ser uma pessoa especial, uma pessoa que realmente tenha a sensibilidade, tenha a sobriedade, né? De fazer nos momentos certos, o jogo com mais risco, com menos risco. Então, ele tem que ser uma pessoa hoje com conhecimento tão grande, quanto o próprio treinador. 


\section{APÊNDICE XIV - S14 - Entrevista com um Técnico Equipe Adulta - Feminino}

1. Quais seriam as variáveis que um levantador deve ter para ser um atleta de alto rendimento e chegar a uma seleção nacional?

Bom, primeiro é o seguinte, eu acho que o levantador não tem tanto estímulo igual o atacante né...igual ao futebol, você vai pega quinze crianças e esses quinze dois vão querer ser atacantes...alguns vão querer ser meio de campo, alguns defesa e os últimos vão querer ser goleiro e voleibol também é assim por que o que ... o maior estímulo que tem o voleibol é o ataque, então toda... criança que ser atacante raramente você pega criança pra ser levantadora, então depende do...da...dos técnicos que trabalha com essas atletas pra sabe desenvolver isso ai, não adianta pega baixinho, se levantador, alto se atacante, isso dura três anos depois a criança baixinha dificilmente ela joga, então acho que os técnicos tem que trabalhar com essa parte ai pra gente pegar um atleta caído do céu acho muito difícil, basta saber que o (...) antigamente era atacante e depois passou a ser levantador, (...), ela era atacante e depois passou a ser levantadora, então acho que mais a parte do...do técnico cativar o atleta do que o atleta ser cativado, isso é um ponto de vista e esse segundo ai, que fala ai, sobre a CBV, aquela assessoria de imprensa é...acho que é bem claro isso ai que pega duzentos atletas e... o auxiliar técnico do Mauro ele fala que teve um só... mas é...eu acho que é bem exatamente isso ai que você ta...você pega assim criança e eles querem ter algum estímulo muito mais forte,então o estímulo mais forte no voleibol é o ataque.Agora a Matéria que a Cida Santos fez também, né que... que ela fala segundo pode ser levantador que vai acabar com o voleibol Brasileiro com as nossas levantadoras acho que seria um assunto pra pensar direito entendeu? Você pega Cuba que tem duas levantadoras e são duas atacantes muito fortes, então se algumas equipes quiser usar isso ai, eles contratam a (...), a (...), só que elas vem pra cá e pode atacar também e são levantadoras que lá em Cuba joga 4 x 2, então acho que é...uma regra que tem que ser muito 


\section{APÊNDICE XIV - S14 - Entrevista com um Técnico Equipe Adulta - Feminino (cont.)}

bem pensada pra gente executar isso ai, agora...futuras jogadoras que eu sou ligado muito mais ao voleibol feminino pelo que eu conheço todas as levantadoras que tô vendo, que eu tô conhecendo ainda, até ate temporada passada, poucas são altas entendeu?... as que são altas estão ficando um pouquinho pra trás por que ela não tem chance de jogar muito, então acho que...eu acho que o problema não é no alto nível e sim na base, os técnicos tem que trabalhar isso na base. 


\section{APÊNDICE XV - S15 - Entrevista com uma Atleta Equipe Adulta - Seleção Brasileira}

1. Quais seriam as variáveis que um levantador deve ter para ser um atleta de alto rendimento e chegar a uma seleção nacional?

Acho que nossa posição...é uma posição assim muito ...é...ela exige muita assim...muita concentração, acho que levantador tem que ser muito concentrado, observador e acho que...isso faz a diferença, a gente não pode ser um atleta assim que vibre demais, que pule demais por que a gente tem que estar concentrado o tempo inteiro, então essa vibração às vezes tira um pouco da concentração...mas acho que observar muito, ser muito observador acho que isso é importante pra você chegar num alto nível. 


\section{APÊNDICE XVI - S16 - Entrevista com um Atleta Equipe Adulta - Seleção Brasileira}

1. Quais seriam as variáveis que um levantador deve ter para ser um atleta de alto rendimento e chegar a uma seleção nacional?

Acho que o primeiro é a liderança né...saber comandar um time, que toda bola passa na sua mão e tem que ter essa tranqüilidade né, de liderar o time. Tecnicamente você sempre tem que estar bem, fisicamente também, e taticamente principalmente, tem que estar sempre pensando, acho que isso é o ...o levantador atinge o seu auge quando ele consegue pensar com mais facilidade dentro da quadra. 


\section{APÊNDICE XVII - S17 - Entrevista com um Atleta Equipe Adulta - Seleção Brasileira}

1. Quais seriam as variáveis que um levantador deve ter para ser um atleta de alto rendimento e chegar a uma seleção nacional?

Bom, eu acho que essas citações ai, acho que tem fundamento sim,o Brasil hoje tá escasso mesmo de levantadores e levantadoras,é...masculino e feminino,é uma realidade que é um futuro ameaçado mesmo, por que um levantador não é feito da noite pro dia,eu acho que tem que ter...eu to na seleção já há quatorze anos...as variáveis pra ser um bom levantador na minha opinião, é determinação, é liderança, é habilidade, é a visão de jogo,é...enfim é conhecer o jogo de voleibol por um todo, é e...psicologicamente você tem que ta sempre bem,por que nos momentos decisivos todos...sempre todas as bolas passam na sua mão, e nos momentos decisivos você tem que ta lúcido, pra saber qual a melhor jogada que você vai fazer,eu acho que é isso,é....é bem por ai mesmo. 
APÊNDICE XVIII - S18 - Entrevista com um Técnico Equipe Adulta - Masculino

1. Quais seriam as variáveis que um levantador deve ter para ser um atleta de alto rendimento e chegar a uma seleção nacional?

Com relação ao negocio da Cida, eu acho que ta errado né , não tem que fazer ou tentar suprir ai o... eficiência trazendo gente de fora, absolutamente e ...que nem, pode-se trazer, como se faz na Itália né, que agora esta exageradamente é absurdamente utilizada né ...de ter times que são verdadeiras legiões estrangeiras né, que entre comunitários é da comunidade européia, italianos e naturalizados estrangeiros e tem time que tem um italiano, então isso pode repercutir muito mau no voleibol Italiano a nível de seleção também, é a mesma coisa com relação a traze uma jogadora estrangeira, dito lá que seja levantadora....ta bom, vai querer crescer no nível dos atacantes, mais e depois na hora da gente ter alguém pra comandar os atacantes numa seleção, como faz?....chama um estrangeiro naturaliza ele?...eu acho meio absurdo isso, eu sou contra...é realmente nos estamos com uma carência de levantadores né e ai eu diria não só tecnicamente, por que o tecnicamente é lógico tem um fator até genético como a gente....é observou lá na palestra é tem o fator genético que auxilia muito, uma carga hereditária que o cara já traz predispondo ele fazendo determinada atividade, só que é....tem alguns aspectos que tão desfavorecendo o surgimento de novos levantadores. Primeiro quem chama atenção no jogo de volei? É o levantador?

Não né!...né...os grandes ídolos....tudo bem (...), ele passou a ser um ídolo, mais por que?...de tanto que a mídia elogiava, de tanto que é pessoal...elogia tal, olha o cara baixo e que sobressaiu, mais você for perguntar pra um moleque hoje, se ele sabe quem é o (...), quem é o (...), ele vai saber quem é o (..), o (...) talvez por que esteja coligado ao (...), ao (...) ao próprio (...), ao (...) né... então a ...como é que eu vou dizer pra você? O garoto que vai começar a jogar o que atrai ele, é o cara que se destaca é o cara que finaliza, é o cara que da porrada, o cara da força né , então isso já é uma coisa que direciona negativamente o jogador jovem né , o garoto que ta querendo começar, é....segunda coisa ....eu acho que o 
APÊNDICE XVIII - S18 - Entrevista com um Técnico Equipe Adulta - Masculino

voleibol ele ta tendo uma quedo muito grande em nível de cognitivo, não vou dizer a nível de inteligência mesmo por que os jogadores estão começando a jogar cada vez mais jovens, saem de casa muito rápido né, eles deixam de ter a orientação dos pais né, é....em 90\% das situações a escola é abandonada, são poucos os clubes como o Banespa que obrigam o garoto a estudar ate pelo menos acabar o colegial né, então isso faz com que o ....a inteligência do garoto seja muito seletiva e voltada diretamente pro voleibol e isso não é uma coisa boa né ....então esse fator ate socialmente, prejudica né, por que o garoto não vai num cinema...não vai sabe?...quero...sabe falar de voleibol, quando sabe né e o universo dele fica cada vez mais restrito, então o cognitivo fica cada vez mais fechado. Ta se fechando você acaba ate diminuindo iniciativa, diminuindo liderança, diminuindo....uma serie de fatores que são imprescindíveis não para levantador, mais pro ser humano tá....é atualmente o que tá acontecendo?....nos temos os levantadores que se sobressaíram as custas de muita...muito trabalho árduo né... mas tinham uma característica social cognitiva que já era de destaque quando garotos né. O (...) me parece um rapaz muito acessível, inteligente, Mauricio a mesma coisa...é vamos dizer, os levantadores que estão ai, se não tem a mesma estrutura familiar socio-cultural é...tiveram que batalhar muito e essa é uma característica que conserva eles nas equipes de ponta que há...da persistência né, da insistência, da vontade, da ralação, como eles falam né...então que acaba dando uma equilibrada nesse panorama, então o que a gente ta tentando fazer aqui no Banespa por exemplo: 


\section{APÊNDICE XVIII - S18 - Entrevista com um Técnico Equipe Adulta - Masculino (cont.)}

Tem o levantador titular no juvenil, do infanto agora, que ele era atacante, ele passou na peneira como atacante né..., só que observando depois melhor...que a peneira normalmente é uma semana, então fica difícil você detectar $100 \%$ esses valores né..., no garoto...lógico que de acordo com o que ele faz na peneira, da pra ver se ele ajuda, se ele xinga, se ele...como que ele se comporta em relação aos outros que são menos privilegiados que ele ...mais depois a gente começou analisar melhor e viu que ele tinha as características é....necessárias pra se tornar um levantador, ai eu entro, aproveito o gancho pra falar ...bom fisicamente eu acho que a gente ta acompanhando uma tendência de elevar a estrutura do levantador, realmente você vê na liga mundial a incidência de ataques em cima do (...) muito grande né , por que? Os atacantes são cada vez maiores, as medias de altura indo lá pro espaço né, então se você tiver um levantador com altura né....condizente ao nível Internacional fica mais fácil em termos de bloqueio principalmente quando a arma muito grande né... dada a potência de ataque né... a variação de ataque se você tiver um bloqueio grande fica mais fácil você consegui ponto através desse fundamento é...agilidade, coordenação motora, pique dinâmico né... tudo aquilo que esta no seu questionário né... são muito importantes e mas acho que ai entre com uma coisa mais pessoal minha né eu acho que da um toque abri uma passada lateral, ou analisar uma trajetória da bola ate noção espaço temporal coisa que você pode treinar ta o que você dificilmente consegue treinar ou consegue embutir na cabeça do jogador jovem é a necessidade dele utilizar as armas que ele tem na mão é... por exemplo, em questão de relacionamento ele tem que ser um líder, ele tem que ter conhecimento dos atacantes dele né... isso já tá embutido na liderança, de o cara ser um líder ele sabe como desfrutar melhor dos seus companheiros, não no sentido pejorativo é... que ele sabe como se comunicar com um e outro, ele 


\section{APÊNDICE XVIII - S18 - Entrevista com um Técnico Equipe Adulta - Masculino (cont.)}

sabe se ele der uma bronca em um jogador ele não vai render e pra ele vai ser ruim, né... ele sabe quem que ele pode por um pouco mais de velocidade que ...que ele não pode por, então ele é respeitado por outros jogadores, ele tem um equilíbrio emocional muito grande por que ele nunca pode perder a cabeça né... a partir do momento que o levantador fica nervoso e para de raciocinar na plenitude, ele deixa de utilizar uma serie de informações durante o jogo que isso é imprescindível para um desempenho dentro do jogo né... para de analisar o time adversário, para de analisar o próprio time né... essa sensibilidade ate de saber se um companheiro dele ta bem ou não na partida independente do técnico tirar ou não né... é ele tem que transmitir confiança né... e nisso ta muito ligado com a parte técnica, treino, trabalho, então é uma coisa global e... e muita arestas pra você realmente ter o jogador de alto nível, que contenha tudo isso né... o (...) por exemplo, atualmente ele tem já um nível de inteligência assim... pro voleibol a ponto de...ele pode odiar um cara que ta jogando com ele né... mas se ele souber que o cara ta bem naquela hora e vai ajudar ele a ganhar ele vai por a bola pra aquele cara né... mas esse discernimento passa só a vir muito com a experiência a gente falando da criação dos novos levantadores é uma

coisa que tem que ser meio nata né... ele tem que ter essa sensibilidade isso é difícil de ser treinado isso é muito difícil essa liderança não ostensiva né mas conquistada sem ter que fazer força é uma coisa que poucos garotos tem, muito poucos garotos, então a gente partiu dessas características pra tirar o (...) de atacante e por como levantador e eu acho que ele vai ser um excelente levantador é um pouco mais alto, tem 1,90...1,92 ,acho...ta crescendo ai... segundo ano de infanto, né... mas são as características que a gente ta procurando ai na garotada para ser levantador. 


\section{APÊNDICE XIX - S19 - Entrevista com uma Atleta Equipe Adulta - Seleção Brasileira}

1. Quais seriam as variáveis que um levantador deve ter para ser um atleta de alto rendimento e chegar a uma seleção nacional?

Pra mim a levantadora é a alma do time né? pq todas as bolas passam pela mão da levantadora, então ela é que sabe o que vai fazer... a jogada que vai fazer, então eu acho que se ela não tiver é..é... um raciocínio um pouco mais rápido e melhor do que uma atacante...é ...bom eu acho que ela não tem condições de jogar lá fora ou mesmo de jogar grandes partidas aqui dentro do Brasil. Pra mim, a principal característica de um levantador é a inteligência, eu acho que um levantador que não é inteligente não consegue jogar jamais...não tem condições de jogar. Eu acho assim...que a gente fala muito de (...), a (...) além dela ser muito habilidosa, ela é extremamente inteligente, então..ela joga com aquela pessoa que tá rodando. Vamos supor, eu já joguei com ela na seleção e calhou de um jogo eu estar muito bem. Eu recebi 50 bolas e a segunda que recebeu, recebeu 3. então ela joga ... ela usa a inteligência dela em função de quem estiver bem, quem tiver rodando ...você não vai esperar a (...) fazer umas jogadas mirabolantes de ta lá na ponta e ela inverter pra saída ou de um fundo. Ela sempre joga aquele jogo mais simples, não que seja simples mas...é mais cadenciado, mas ela é extremamente inteligente por causa disso, e eu digo assim...é...a alma do time pq , a gente ...todas as atacantes precisam esperar pela levantadora pra fazer uma ação. Então a gente precisa sempre esperar por ela, e se...ela.. por exemplo não tiver no jogo, não tiver bem naquele dia , não tem jogo, acabou o jogo, né? Pq não tem o que você fazer, não tem o que uma atacante resolver, pq ela não vai tocar na bola e sempre a bola vai passar pela levantadora. Eu acho por isso a levantadora é a alma do time. 


\section{APÊNDICE XX - S2O - Entrevista com um Técnico Categorias Menores}

1. Quais seriam as variáveis que um levantador deve ter para ser um atleta de alto rendimento e chegar a uma seleção nacional?

Olha... eu até gostaria de comentar um pouquinho acima se puder é...a falha é de todo mundo de não ter levantador, primeiro,toda menina pequenininha é a que vai ser a levantadora e não a talentosa a grande que poderia ser uma excelente levantadora, ela não.....pra fruto próprio do técnico e do clube ela vai ataca três, quatro anos, quando ela virar levantadora outra pequenininha esta seis anos na frente dela e leva vantagem, eu acho que a primeira falha já começa ai...é....depois eu acho que assim, pra ...hoje...primeiro requisito num levantador, tem que ser inteligente, inteligente eu digo, tem que ser uma pessoa tranqüila, tem uma ...tem que ser uma pessoa ou um atleta de raciocínio rápido e que assimile a ... o jogo em si, eu não simplesmente jogue a bola mecanicamente que é o que a gente vê, eu não vou dizer nomes, mais eu acho uma (...) uma craque de bola, que sabe raciocinar durante o jogo e outras levantadoras no Pais, feminino que são bem treinadas, elas são bem treinadas, elas não sabem o que elas estão fazendo, me desculpe, mais essa é a minha opinião. 


\section{APÊNDICE XXI - S21- Entrevista com uma Atleta Equipe Adulta - Seleção Brasileira}

1. Quais seriam as variáveis que um levantador deve ter para ser um atleta de alto rendimento e chegar a uma seleção nacional?

É eu acho...primeiro eu acho que ele tem que ser muito bom tecnicamente e segundo eu acho que ele tem que ter muita percepção. Eu acho que tem determinados momentos do jogo que ele tem que perceber quem é que ta melhor, quem é que tem que receber aquela bola, independente de qual bola seja. Eu acho que isso é o mais importante pro levantador... pq tem momento no jogo, por ex. 23 a 23 que ele tem que perceber quem é que ta melhor psicologicamente e com coragem pra decidir aquela bola. Ele não pode né? No 23 a 23 dar uma bola pra aquela pessoa que errou as três bolas anteriores ou que ele sentiu que não ta bem. Então...é um momento de decisão então eu acho que ele tem que perceber quem é que ta melhor naquele momento pra poder ganhar o jogo na verdade. 
APÊNDICE XXII - S22 - Entrevista com um Técnico Equipe Adulta - Feminino

1. Quais seriam as variáveis que um levantador deve ter para ser um atleta de alto rendimento e chegar a uma seleção nacional?

Antes de mais nada é, é muito difícil hoje em dia vc, vc, quando vc faz uma peneira você, como é que vc é, vai tentar saber se se a, se ele pode ser levantador, porque se é primeiro vc vai olhar o toque dele, né, então eu vou começar assim pra tentar te responder, pra que vc me faça entender. Então vc vai olhar o toque dele, aí tem o toquezinho bonitinho, tal, .............Aí que então o técnico opta pra que ele seja um levantador. Aí, mais pra frente é que vc, eu acho, que um levantador, ele só pode ser definido quando ele tem, quando ele vai ser um craque de bola, craque,... ele pode ser até um craque de bola, mas não precisa ser um levantador, na minha opinião depois dos 25 anos, essa é minha opinião. Eu acho que com 25 anos ele ta madura, ele ta apto, até mais às vezes, vc vê hoje em dia o nosso, o (...) hoje em dia ainda é o melhor levantador do país, eu fui é, eu modéstia a parte, seleção brasileira até 35 anos também, e até que pintou o (...) pra poder me substituir, então é essa a dificuldade, então vc, hoje em dia pinta muitos levantadores bons né, assim todo mundo fala ah. Esse vai ser um craque juvenil, ce não pode definir nada sobre isso, minha opinião, isso vai ter principal a concentração né, o nível de concentração, o domínio, o domínio, vc tem que ter uma uma uma reação de de poucos segundos, vc tem que saber pra onde vc vai distribuir uma bola, pra quem vc vai levantar, o atacante que psicologicamente naquele momento ta bom, vc tem que olhar o bloqueio adversário e tudo isso numa fração de segundos que vc só passa a , a entender, a a fazer isso com, com uma precisão depois dos 25 anos até mesmo a entender taticamente o que o seu treinador pede a vc. Até então, vc está numa empolgação, vc vai numa empolgação física e às vezes vc até se destaca, mas eu acho que ele atinge a maturidade após os 25 anos, isso pro levantador. 


\section{APÊNDICE XXIII - S23 - Entrevista com uma Atleta Equipe Adulta - Seleção Brasileira}

1. Quais seriam as variáveis que um levantador deve ter para ser um atleta de alto rendimento e chegar a uma seleção nacional?

Eu acho que para o voleibol o lado psicológico é muito mais importante do que o lado físico, né? Porque sei lá, num jogo exige do levantador, fisicamente você tem que estar bem, mas exige muito mais do atacante do que do levantador. O levantador realmente tem que estar com a cabeça ligado, pensando durante o tempo todo do jogo, entender o que está sendo feito, o que tem que ser feito, a estratégia que tem que ser feita, ah. Pra jogar contra o adversário, então o lado psicológico do levantador é muito mais importante do que o lado físico. 
APÊNDICE XXIV - S24 - Entrevista com um Técnico Equipe Adulta - Feminino

1. Quais seriam as variáveis que um levantador deve ter para ser um atleta de alto rendimento e chegar a uma seleção nacional?

Olha... eu acho que o principal de um levantador...na parte psicológica...por que as vezes...muitas vezes quando tem deficiência física e deficiência técnica, ele consegue fazer o jogo pelo controle emocional dele e pelo controle que ele tem sobre a avaliação que ele faz dos companheiros de jogo dele...eu vou falar mais em termo de feminino por que é onde eu mais trabalho...então eu entendo que as variáveis psicológicas do controle emocional a observação e a facilidade de analise do colega...qual momento eu posso usar esse jogador, qual o momento eu não posso usar esse jogador, a identificação de como o jogador reage com determinado tipo de bola ...qual é a maior eficiência dele qual a maior deficiência dele, como se dirigir com o jogador que ela vai levantar a bola, se ela deve ser agressiva, se ela deve ser carinhosa, se ela deve ser atenciosa...então eu acho que esse é um componente fundamental pra uma levantadora de altíssimo nível....por a bola pra cima um monte de gente saber por...Ate eu , agora ter esse tipo de avaliação eu acho que é fundamental pra eu levantador, ser diferenciado dos outros e eu acho que isso diferenciou todos os grandes levantadores do mundo...e hoje a gente tem ai dois do Brasil, (...) e o (...) que são exemplo claro disso. Das variantes físicas a gente encontra em qualquer livro isso, a velocidade, deslocamento, a velocidade de reação, a qualidade de salto...principalmente de resistência de salto...isso é uma coisa que a gente vem debatendo bastante e procurando trabalhar ate nas categorias de base, por que a gente já fez levantamento sobre o jogador que mais salta no voleibol, desde que seja de alto nível, é o levantador, muito mais do que o jogador central como era de pensamento de algumas pessoas...o levantador é o que mais salta, por que a bola passa por ele o tempo inteiro, se ele toca em suspensão, mais ainda....então normalmente o jogador que mais salta em alto nível, é o levantador, em números de saltos em uma partida....então a resistência de salto, ele não precisa ter um salto altíssimo, mas ele precisa resistir ....ter uma 


\section{APÊNDICE XXIV - S24 - Entrevista com um Técnico Equipe Adulta - Feminino (cont.)}

resistência de salto boa pra manter aquele padrão de equilíbrio, principalmente ....então é o equilíbrio, é agilidade , é a resistência de salto, é a força muscular, força de cintura escapular, força de dedos, equilíbrio de dedos e punhos, pra musculatura de flexor e extensor dos dedos.....eu acho que essas são as que sai do geral e bem especifico do levantador. A qualidade seria a variação, o domínio de todos os tipos de variações de toque e de manchete, por que varias situações o jogador não tem possibilidade de chegar de toque e ele tem que ser um bom levantador também de manchete, ter um controle da manchete, o que a gente observa muito, é que o jogador de alto nível, sempre é o melhor defensor da equipe, hoje com a existência do libero caiu um pouco, mas normalmente....você vê , a (...) já ganhou varias vezes como melhor defensora da super liga e o (...) também, sempre os levantadores estão a frente, por que eles tem um percepção, uma analise melhor de trajetória de bola, uma analise melhor do atacante pra se posicionar...então essa antecipação ....que também na parte física eu esqueci de colocar ....que é fundamental pra um levantador, essa antecipação da ação que vai acontecer, ou antes ou depois dele. 